\title{
Transduction in Olfactory Receptor Neurons of Xenopus laevis Larvae: Pharmacological Blockage with FM1-43 and Endocannabinoid Modulation
}

\author{
PhD Thesis \\ in partial fulfillment of the requirements for the degree "Doctor of \\ Philosophy (PhD)/Dr. rer. nat." in the Neuroscience Program at \\ the Georg August University Göttingen, Faculty of Biology
}

submitted by

Esther Breunig

born in Buchen

September 2009 
Herewith I declare that I prepared the $\mathrm{PhD}$ Thesis "Transduction in Olfactory Receptor Neurons of Xenopus laevis Larvae: Pharmacological Blockage with FM1-43 and Endocannabinoid Modulation" on my own and with no other sources and aids than quoted.

Göttingen, September $7^{\text {th }}, 2009$

Advisor, first member of PhD committee: Prof. Dr. Dr. Detlev Schild Second member of PhD committee: Prof. Dr. Tobias Moser Third member of PhD committee: $\quad$ Prof. Dr. Walter Stühmer

Date of submission of the PhD thesis: September $7^{\text {th }}, 2009$ 


\section{Table of Contents}

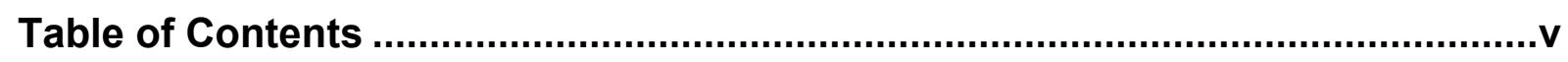

List of Figures .............................................................................................. vii

List of Tables .................................................................................................ix

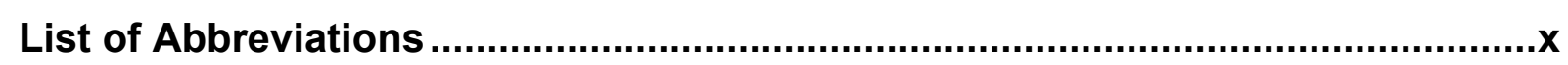

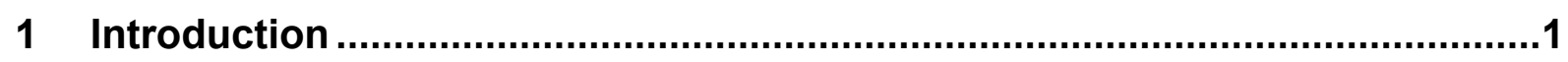

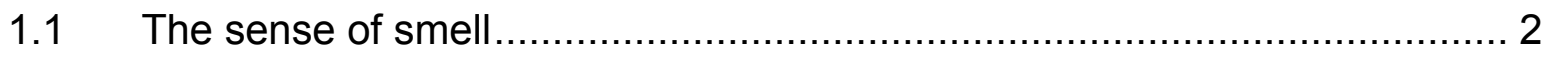

1.1.1 Morphology of the olfactory system ........................................... 2

1.1.2 Olfactory transduction and transformation in ORNs .......................... 4

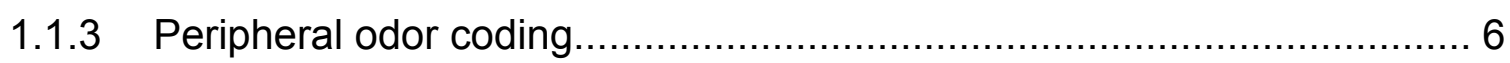

1.2 The effect of endocannabinoids on olfaction..................................... 8

1.2.1 Modulation of olfactory processing in the OE ................................. 8

1.2.2 Physiological role of the endocannabinoid system ............................ 10

1.2.3 Biochemical aspects of the endocannabinoid system ........................ 11

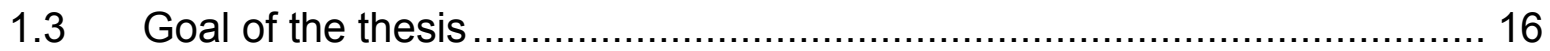

2 Materials and Methods .......................................................................18

2.1 Xenopus laevis tadpoles as the experimental model ............................ 18

2.2 In vivo labeling of ORNs with FM1-43 .......................................... 21

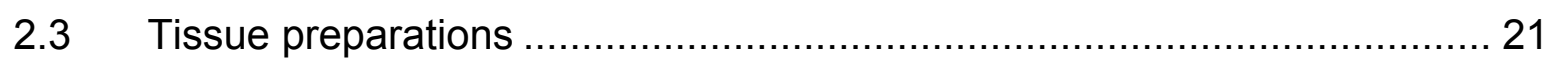

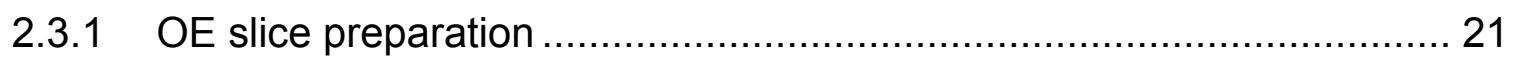

2.3.2 Olfactory bulb whole mount preparation ...................................... 22

2.4 Conventional and advanced $\left[\mathrm{Ca}^{2+}\right]_{\mathrm{i}}$ imaging and patch clamp

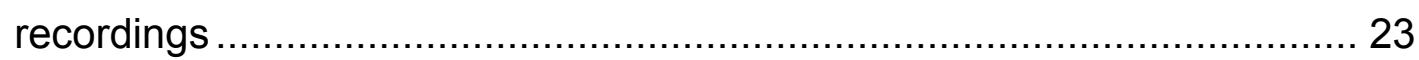

2.4.1 $\left[\mathrm{Ca}^{2+}\right]_{\mathrm{i}}$ imaging of odor-induced responses of ORNs and glomeruli with confocal microscopy .................................................... 23

2.4.2 Uncaging of cAMP in ORNs viewed with confocal microscopy............. 24

2.4.3 $\left[\mathrm{Ca}^{2+}\right]_{i}$ dendrite imaging in tissue slices with a fast scanning line illumination microscope .................................................... 25

2.4.4 Patch-clamp recordings of the CNG current .................................. 25

2.4.5 Bathing conditions and stimulus application ................................ 26

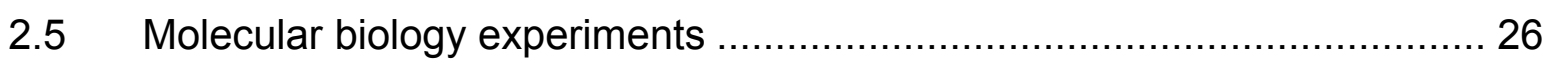

2.5.1 Single-cell reverse transcription (RT) PCR .................................. 26 


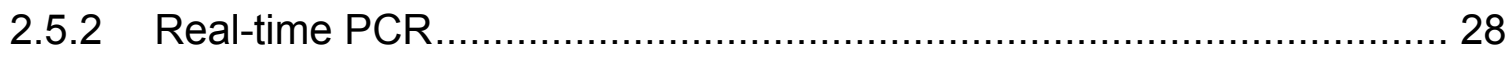

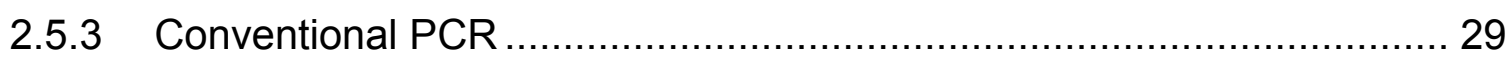

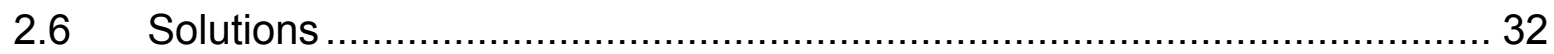

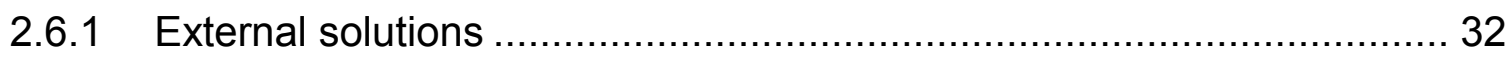

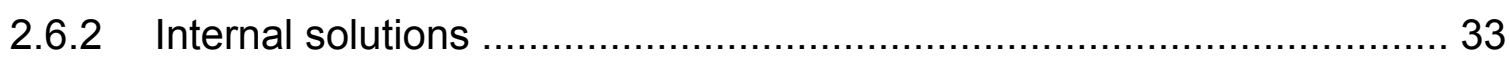

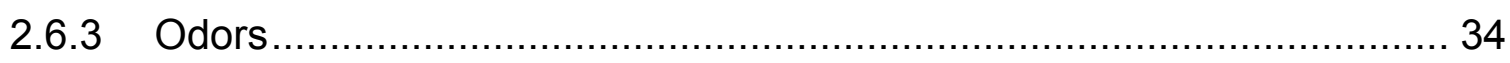

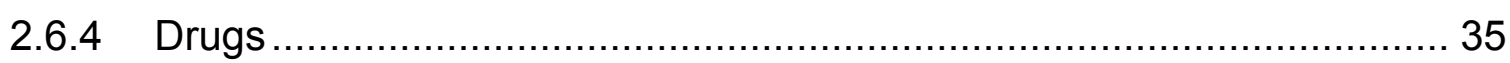

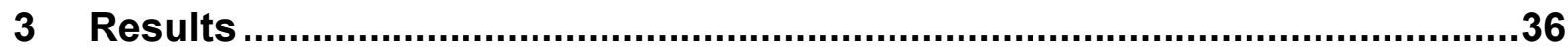

3.1 The styryl dye FM1-43 permeates and blocks CNG channels in olfactory receptor neurons of larval Xenopus laevis ............................... 36

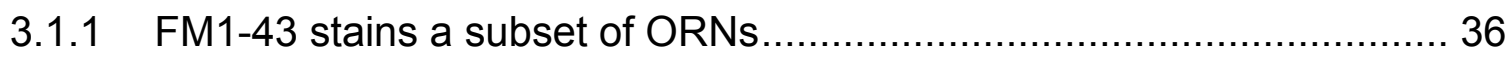

3.1.2 FM1-43-stained ORNs rarely respond to odors .................................. 36

3.1.3 FM1-43 is selectively internalized by CNG channels ........................... 39

3.1.4 FM1-43 inhibits CNG currents .................................................. 42

3.1.5 Extracellular FM1-43 in the OE reduces forskolin-induced

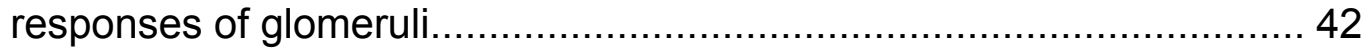

3.2 Modulation of processing in olfactory receptor neurons by the

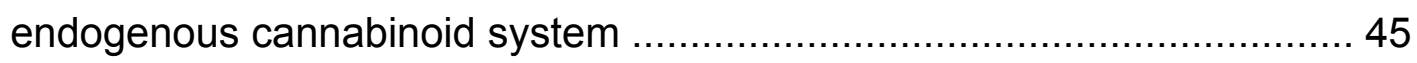

3.2.1 Localization of the endocannabinoid system in OE ............................. 45

3.2.2 Suppression of 2-AG production reduces and delays odor-induced

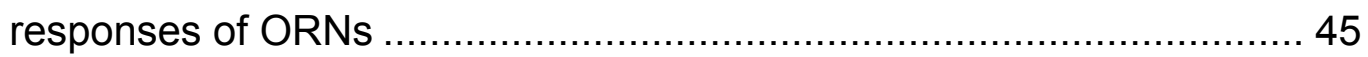

3.2.3 Differential expression of the DAGL isoforms within the OE ................ 46

3.2.4 DAGL $\alpha$ expression is enhanced after food-deprivation ....................... 48

3.2.5 The endocannabinoid level tunes odor thresholds of individual ORNs.

3.2.6 Preliminary: PMCA is effector molecule of the CB1 receptor in ORNs.

3.2.7 Endocannabinoid system and receptors for other modulators in the

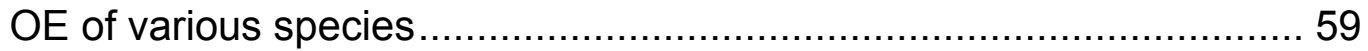

4 Discussion

4.1 The styryl dye FM1-43 permeates and blocks CNG channels in olfactory neurons of larval Xenopus laevis............................................. 60

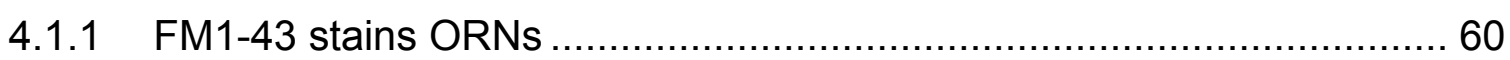

4.1.2 FM1-43 uptake in ORNs through CNG channels ............................... 61 
4.1.3 Only ORNs endowed with the cAMP transduction machinery internalize FM1-43.

4.1.4 Extracellular FM1-43 inhibits cation currents through CNG channels.... 64

4.1.5 Conclusion

4.2 Modulation of processing in olfactory receptor neurons by the endogenous cannabinoid system ..............................................6 68

4.2.1 The endocannabinoid 2-AG acts in the OE ................................. 68

4.2.2 Cellular localization of 2-AG synthesis and its functional meaning ........69 69

4.2.3 2-AG level modulates odor detection thresholds ............................ 71

4.2.4 Novel CB1 transduction cascade in ORNs: PMCA as effector molecule

4.2.5 Endocannabinoid and other modulatory systems exist in the OE of Xenopus laevis tadpoles and mammals ................................... 73

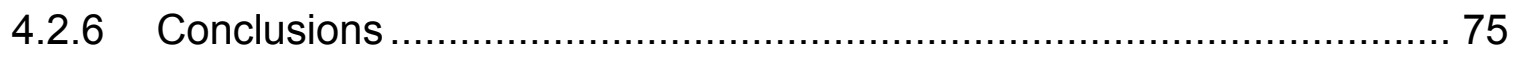

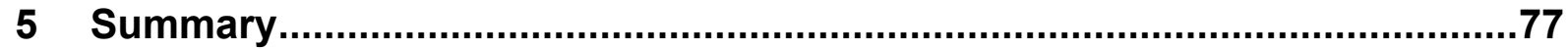

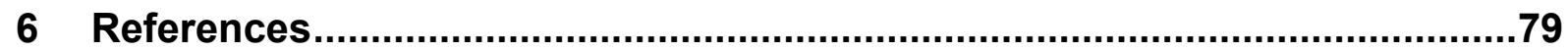

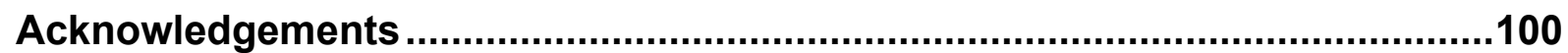

Curriculum Vitae ....................................................................................101

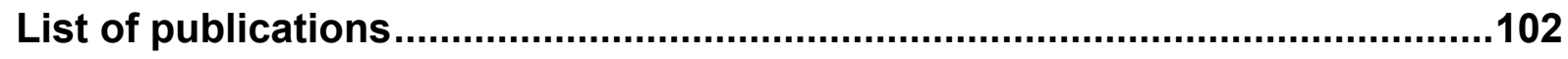




\section{List of Figures}

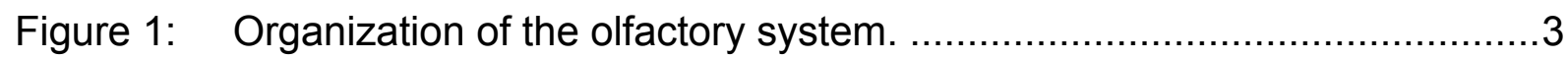

Figure 2: cAMP-dependent olfactory transduction. .................................. 5

Figure 3: Distribution of CB1 receptors in the central nervous system. ...............12

Figure 4: Anabolic and catabolic pathways of anandamide and 2-AG...............13

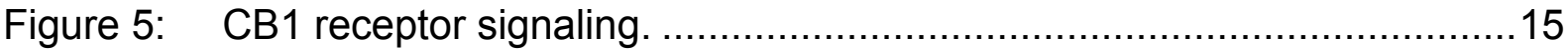

Figure 6: Immunohistochemical staining of the OE of Xenopus laevis larvae........19

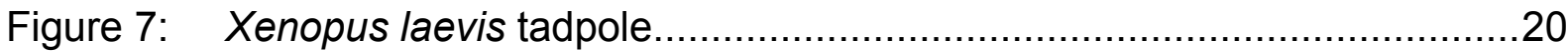

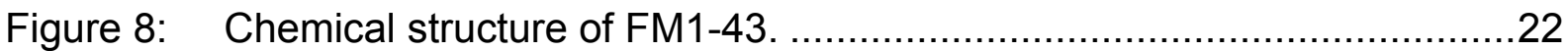

Figure 9: FM1-43 is selectively internalized by a subset of ORNs.....................37

Figure 10: Odor-induced $\left[\mathrm{Ca}^{2+}\right]_{i}$ transients of an FM1-43-stained ORN.................38

Figure 11: Block of FM1-43 labeling by cations. ........................................ 39

Figure 12: Block of FM1-43 labeling by unspecific CNG channel blockers............40

Figure 13: FM1-43-labeled ORNs are sensitive to forskolin and uncaging of CAMP.

Figure 14: CNG currents are inhibited by FM1-43. ..................................... 43

Figure 15: Extracellular FM1-43 inhibits glomerular responses. .........................44

Figure 16: Endocannabinoid system in the OE of tadpoles. ..............................46

Figure 17: RHC80267 and orlistat suppress odor-evoked $\left[\mathrm{Ca}^{2+}\right]_{\mathrm{i}}$ transients...........47

Figure 18: Differential DAGL $\beta$ and $\alpha$ expression in ORNs and sustentacular

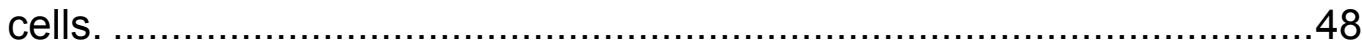

Figure 19: DAGL mRNA expression is regulated upon food-deprivation. ...............49

Figure 20: Dose-response relationships of $\left[\mathrm{Ca}^{2+}\right]_{i}$ transients induced by single amino acids.

Figure 21: ORNs have individual and tunable odorant detection thresholds according to the 2-AG level in the OE.

Figure 22: Summary of detection threshold modulation .53

Figure 23: PMCA but not NCX mediates CB1 receptor-induced effects. .54

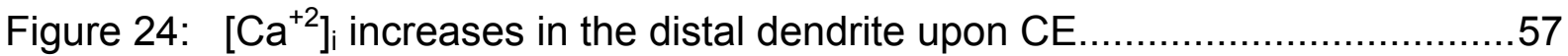

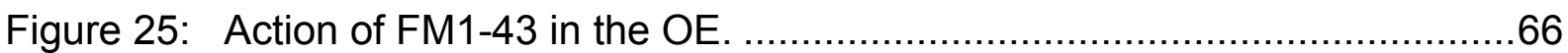

Figure 26: Scheme of endocannabinoid action in the OE................................76 


\section{List of Tables}

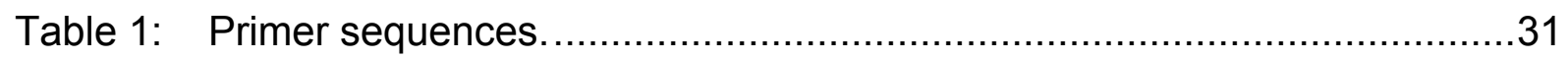

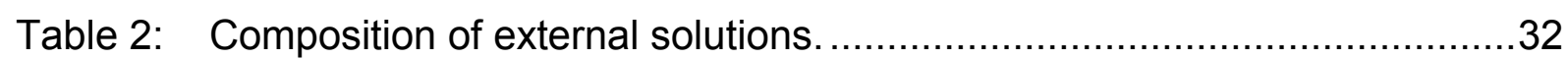

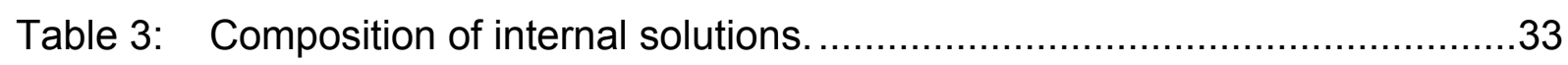

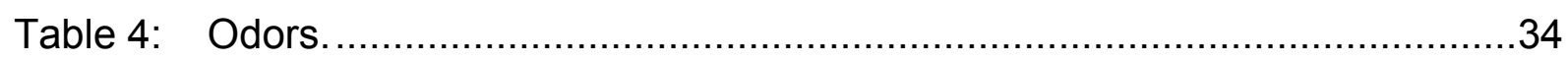

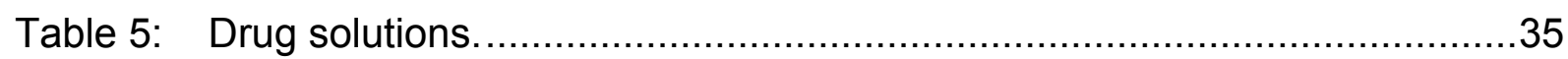

Table 6: mRNA of the components of the endocannabinoid system and receptors for other modulatory substances....................................59 


\section{List of Abbreviations}

2-AG 2-arachidonoylglycerol

ATP Adenosine triphosphate

$\left[\mathrm{Ca}^{2+}\right]_{\mathrm{i}} \quad$ Intracellular $\mathrm{Ca}^{2+}$ concentration

CAMP Cyclic adenosine monophosphate

CB Cannabinoid

CE SE(5-(and-6)-carboxyeosin diacetate, succinimidyl ester)

cGMP Cyclic guanosine monophosphate

CNG Cyclic nucleotide-gated

DAGL $\alpha, \beta \quad$ Diacylglycerol lipase $\alpha, \beta$

DMSO Dimethyl sulfoxide

EDTA Ethylenediaminetetraacetic acid

EGTA Ethylene glycol tetraacetic acid

FAAH Fatty acid amide hydrolase

FM1-43 N-(3-triethylammoniumpropyl)-4-(4-(dibutylamino)styryl)pyridinium dibromide

$\mathrm{G}_{\text {olf }} \quad$ Olfactory-specific guanosine triphosphate (GTP)-binding protein

GTP Guanosine triphosphate

HEPES 4-(2-hydroxyethyl)-1-piperazineethanesulfonic acid

MAGL Monoacylglycerol lipase

MAP Mitogen-activated protein

NAPE-PLD $\quad \mathrm{N}$-acylphosphatidylethanolamide-hydrolyzing phospholipase D

NCX Sodium calcium exchanger

NMDG N-Methyl-D-glucamine

OE Olfactory epithelium

ORN Olfactory receptor neuron

PCR Polymerase chain reaction

PMCA Plasma membrane calcium ATPase

RT PCR Reverse transcription polymerase chain reaction

TAE Tris acetate EDTA

Abbreviations exclusively used in figures are explained in the respective figure legends. 
"Smell is a potent wizard that transports us across thousands of miles and all the years we have lived. The odors of fruits waft me to my southern home, to my childhood frolics in the peach orchard. Other odors, instantaneous and fleeting, cause my heart to dilate joyously or contract with remembered grief. Even as I think of smells, my nose is full of scents that start awake sweet memories of summers gone and ripening fields far away." 


\section{Introduction}

The sense of smell enables almost all species of the animal kingdom to recognize and discriminate between a large array of molecules called odors with a great accuracy and sensitivity. Especially in humans, this sense was regarded as a kind of luxury, but in fact, animals heavily depend on detecting molecules in the environment in order to survive as a successful organism. This makes olfaction one of the most remarkable senses, but it is also the least understood.

The olfactory system is a chemosensory system, indispensable for the interplay of an organism with its environment. This sense is of particular importance as it allows to identify about 10,000 odors (for humans, Mombaerts, 2004), and it has a tremendous impact on a variety of behavioral patterns. Olfaction is a significant sensory input for appetite regulation and food seeking behavior. Most animals including humans use olfactory information in order to appreciate food palatability and to initiate food intake (Rolls, 2005; Yeomans, 2006). Furthermore, the olfactory system influences emotional responses like anxiety, fear, and pleasure, reproductive functions like sexual and maternal behaviors as well as social behaviors like recognition of conspecifics and predators (Schultz and Tapp, 1973; Nimmermark, 2004; Takahashi et al., 2005). Olfaction is often underestimated, but its significance becomes obvious in the case of its loss. Many patients with impaired olfaction have a poor quality of life and develop feelings of personal isolation, lack of interest in eating, and emotional blunting. Moreover, olfactory disorders are associated with depression (Toller, 1999; Nordin and Brämerson, 2008). It is now apparent that dysfunction of olfaction is one of the first symptoms of neurodegenerative diseases like Alzheimer's and Parkinson's disease (Doty, 2008; Doty, 2009), and it is associated with many other cognitive diseases like schizophrenia or Huntington's disease (Lombion-Pouthier et al., 2006; Lazic et al., 2007; Atanasova et al., 2008).

The increasing understanding of the links between olfaction and various diseases will eventually lead to the discovery of new disease mechanisms, which in turn introduce new targets for drug development. This is of particular importance since none of the diseases mentioned above can be cured to date. However, before functional links in this field can be established, further knowledge about olfaction 
itself has to be gained. Regarding the first steps of peripheral odor encoding, two questions need to be addressed for a better understanding of the mechanisms underlying olfaction:

By which mechanisms are odors coded in the neuronal substrates?

How is odor coding modulated by intrinsic and extrinsic factors?

In this thesis, significant findings are presented that contribute to answer these questions. Before showing the results I obtained during the last three years, I would like to introduce basic principles of olfaction, as far as they are important for a better understanding of the results. Section 1.1 summarizes the organization of the olfactory mucosa and principles of odor encoding by olfactory receptor neurons. In section 1.2 the current understanding of modulatory principles in the olfactory mucosa are summarized. Especially the endocannabinoid system is highlighted: on the one hand the importance of this system for olfaction is elaborated, on the other hand the common physiological importance of endocannabinoids and their mechanism of action are illustrated.

\subsection{The sense of smell}

\subsubsection{Morphology of the olfactory system}

The olfactory system in vertebrates can roughly be divided into the olfactory epithelium (OE), the olfactory bulb, and higher brain centers. The first steps of odor detection take place in the $\mathrm{OE}$, whereas further processing takes place centrally. The $\mathrm{OE}$ is located in the nasal cavity embedded under a layer of mucus, which is secreted by olfactory glands (primarily Bowman's glands) and sustentacular cells (Getchell, 1986; Gold, 1999, Schwob, 2002). This epithelium contains three main cell types (Figure 1):

1. Olfactory receptor neurons (ORNs; Figure 1, upper part, orange) are bipolar neurons. These primary sensory cells transduce and transform the binding of ligands to olfactory receptors into sequences of action potentials. From the 


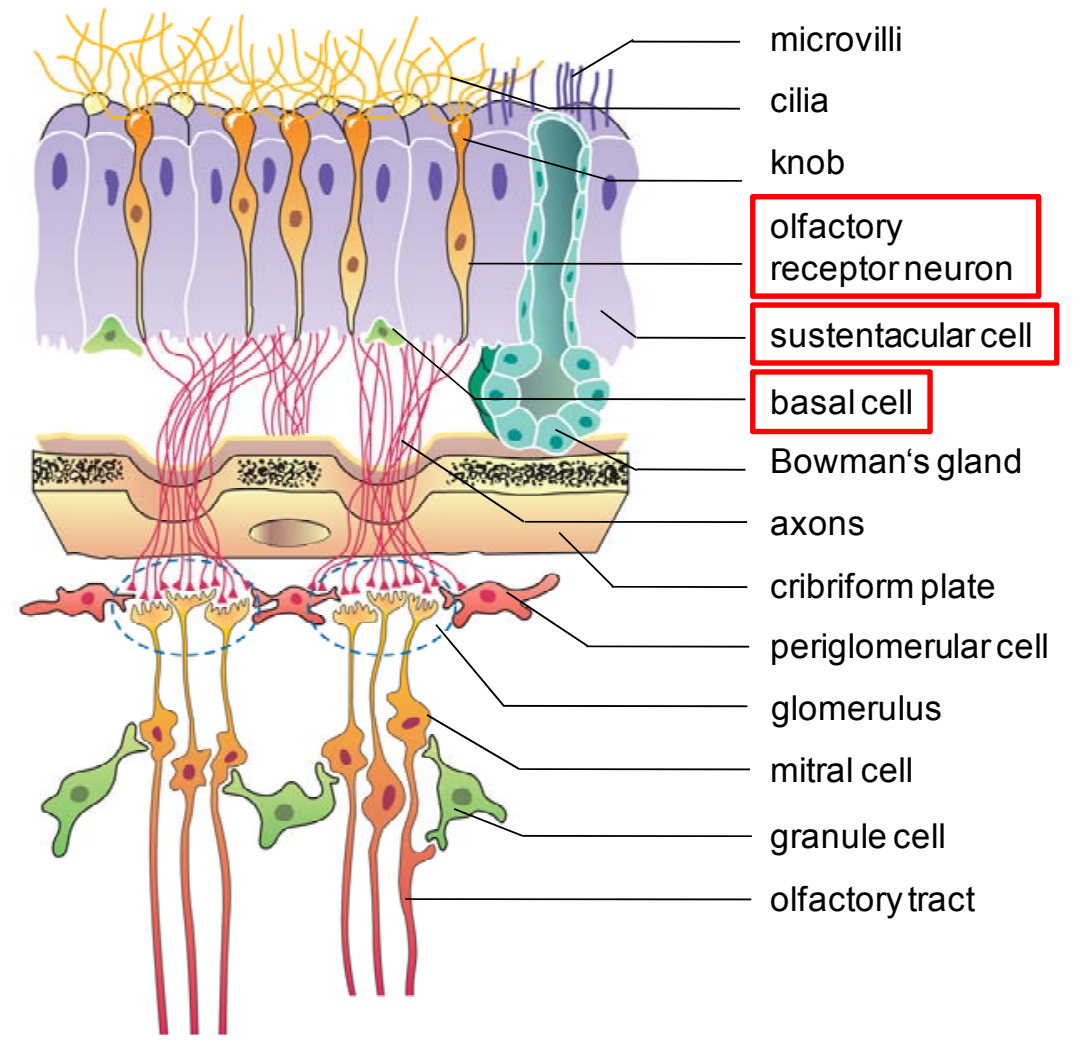

Figure 1: Organization of the olfactory system. The morphology of the olfactory system is illustrated in this sketch. Figure modified from Lang and Lang (2007); In "Basiswissen Physiologie", page 429; 2nd edition; Springer Berlin Heidelberg Verlag.

small soma, a single dendrite extends to the nasal cavity and ends in a knob bearing cilia. In cilia olfactory transduction takes place upon binding of odors to the receptors situated in the membrane. On the basal side of the soma an unmyelinated axon originates and projects via the olfactory nerve to the olfactory bulb (Getchell, 1986; Schild and Restrepo, 1998; Gold, 1999).

2. Sustentacular cells (Figure 1, purple) have multi-faceted functions in the OE. Besides their role in mucus secretion and regulation of the ionic content of the mucus (Getchell and Getchell, 1992; Hansen et al., 1998) they have a glia-like function and insulate ORNs physically and chemically (Breipohl et al., 1974; Getchell and Getchell, 1992), phagocytose dead cells (Suzuki et al., 1996), 
and detoxify noxious substances (Lazard et al., 1991). Recently it was suggested that sustentacular cells play a role in intraepithelial signaling, e.g. in cell proliferation by purinergic signaling (Hegg and Lucero, 2006; Hassenklöver et al., 2008; Hassenklöver et al., 2009). Sustentacular cells are arranged columnar at the apical side of the OE and are either ciliated or secretory.

3. Basal cells (Figure 1, upper part, green) represent the stem cells within the $\mathrm{OE}$ and are responsible for cell regeneration. The life span of ORNs is 30 to 60 days and they have to be replaced continuously due to the exposure of the $\mathrm{OE}$ to a variety of toxic agents. The consequential cell damage and death is compensated by differentiation of basal cells into ORNs and sustentacular cells (Schwob, 2002; Ronnett and Moon, 2002).

Each mature ORN relays electric information via its axon running in the olfactory nerve to the olfactory bulb, which is separated from the OE by the cribriform plate in adult vertebrates (Figure 1). There, it forms synapses in specialized structures called glomeruli. Two types of interneurons are involved in the olfactory processing in the bulb: periglomerular cells and granule cells. The output neurons of the olfactory bulb, the mitral cells, are glutamatergic and convey olfactory information to the primary olfactory cortex (Mori et al., 1999; Lledo et al., 2005; Wilson and Mainen, 2006).

\subsubsection{Olfactory transduction and transformation in ORNs}

\section{Olfactory transduction}

The first step in perceiving an odor is the interaction of the odorant molecule with the olfactory receptor on cilia of ORNs (Figure 2). These receptors belong to the family of seven transmembrane receptors and are encoded by about 1000 separate genes in rat and mouse and 400 in frog (Buck and Axel, 1991; Mombaerts, 1999; Niimura and Nei, 2006). The interaction of odors with the receptors leads to the intracellular activation of an olfactory-specific guanosine triphosphate (GTP)-binding protein called $G_{\text {olf. }}$ The $\alpha$-subunit of this $G$ protein in turn mediates the activation of adenylate 


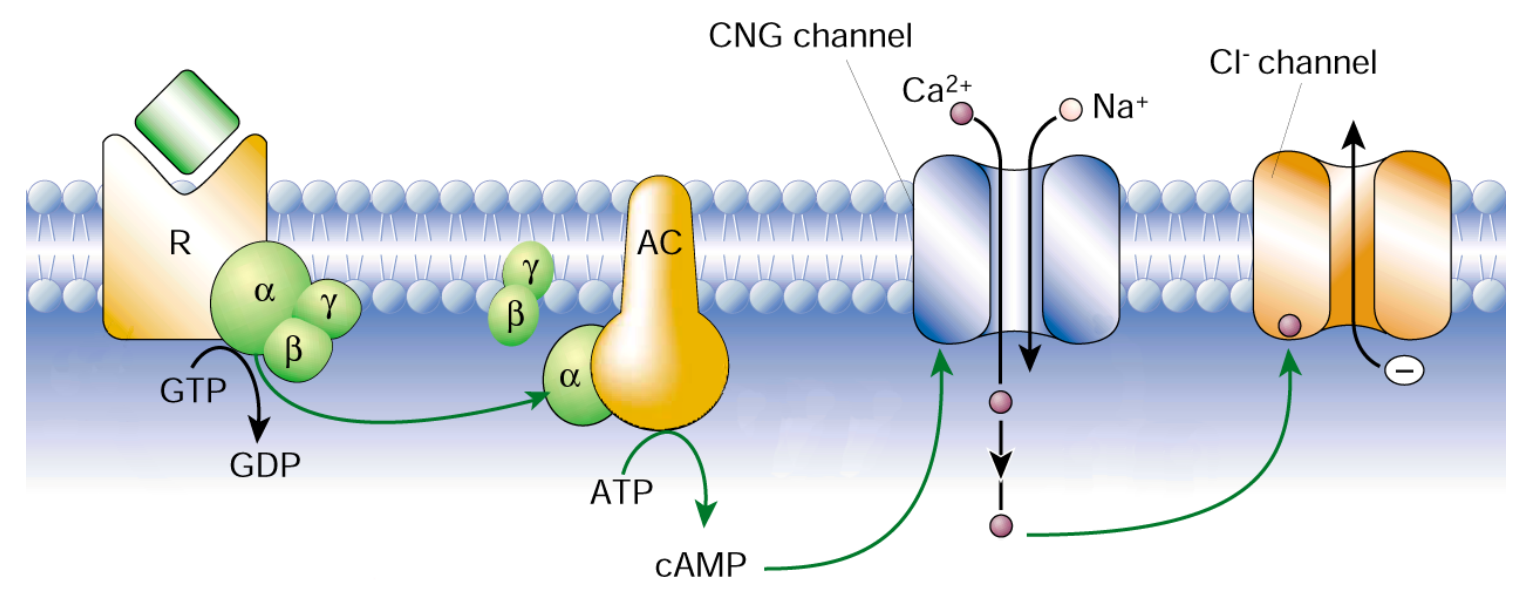

Figure 2: cAMP-dependent olfactory transduction. Upon binding of an odor (green square) to an olfactory receptor $(R)$ in the ciliary membrane, GTP bound to $G_{\text {off }}$ is hydrolyzed. This leads to the dissociation of the a-subunit which activates the adenylate cyclase (AC). Subsequently, cAMP gates CNG channels which are permeable for cations. Influx of $\mathrm{Na}^{+}$and $\mathrm{Ca}^{2+}$ leads to both depolarization of the membrane and opening of $\mathrm{Ca}^{2+}$ dependent $\mathrm{Cl}^{-}$channels which results in a further depolarization by a $\mathrm{Cl}^{-}$efflux. Figure modified from Firestein (2001).

cyclase III. This membrane-bound enzyme catalyzes the reaction of ATP to cAMP, which opens cyclic nucleotide-gated (CNG) channels (Dhallan et al., 1990) that are permeable for cations including $\mathrm{Na}^{+}$and $\mathrm{Ca}^{2+}$. The subsequent current both depolarizes the cell membrane and $\mathrm{Ca}^{2+}$ intracellularly opens $\mathrm{Ca}^{2+}$-activated $\mathrm{Cl}^{-}$ channels (Stephan et al., 2009), resulting in an efflux of $\mathrm{Cl}^{-}$ions. Due to the elevated equilibrium potential of $\mathrm{Cl}^{-}$, the cell membrane is further depolarized (Schild and Restrepo, 1998; Kleene, 2008).

The cAMP-dependent transduction mechanism appears to be predominant particularly in terrestrial vertebrates. However, besides this well described pathway also non-cAMP-dependent transduction mechanisms exist (Schild and Restrepo, 1998; Manzini et al., 2002). These comprise inositol 1,4,5,-tris-polyphosphate as a second messenger (Kaur et al., 2001; Bruch, 1996) as well as nitric oxide and carbon 
monoxide (Breer and Shepherd, 1993; Broillet and Firestein, 1996). Furthermore, odors induce not only excitatory responses in ORNs, but they can also elicit inhibitory responses in other ORNs (Vogler and Schild, 1999; Morales et al., 1997).

\section{Olfactory transformation}

The receptor potential, which is generated in cilia, propagates electrotonically to the soma. Because of their small membrane capacitance, high membrane resistance, and long time constant (Schild et al., 1994; Schild and Restrepo, 1998; Imanaka and Takeuchi, 2001) ORNs are highly sensitive to odorant stimulation. If the potential at the soma reaches threshold, voltage-gated $\mathrm{Na}^{+}$channels open at the axon hillock, thus generating an action potential. This strong depolarization then activates voltagegated $\mathrm{Ca}^{2+}$ channels (high-voltage-activated, activated between $-30 \mathrm{mV}$ and $-40 \mathrm{mV}$ ) at the proximal dendrite. $\mathrm{Ca}^{+}$-dependent $\mathrm{K}^{+}$channels at the proximal dendrite and voltage-gated $\mathrm{K}^{+}$channels at the axon hillock serve to repolarize the cell membrane and to terminate the action potential (Schild, 1989; Schild et al. 1994). Action potentials are conveyed via the olfactory nerves towards the olfactory bulb where further processing takes place (Wilson and Mainen, 2006; Toida, 2008).

\subsubsection{Peripheral odor coding}

Olfactory receptor neurons detect many odors with their qualitative, quantitative, and temporal information. A single odorant can activate multiple olfactory receptors and one olfactory receptor can bind many odorants. The hypothesis of one olfactory receptor type per ORN is reevaluated and the probability of the expression of more than one olfactory receptor per ORN is discussed (Rawson et al., 2000; Mombaerts, 2004; Tian and Ma; 2008).

Moreover, the OE consists of ORN subsets, which can be classified e.g. according to their odor sensitivity, maturation state, and transduction cascade. Regarding the second messenger cascades, there exist multiple types in the OE of various species (Schild and Restrepo, 1998; Manzini et al., 2002) and some may even be coexpressed within one cell (Ko and Park, 2006). This means that odor 
coding is a complex process and that ORN subsets work not only in parallel but may also interact or are coactivated.

In order to understand peripheral odor coding mechanisms, ORN subsets need to be characterized in detail. Tools, allowing interference with single ORN subtypes are required. To date, the differentiation of ORN subtypes according to the olfactory receptor expression is possible by genetic manipulation (Mombaerts et al., 1996; Grosmaitre et al., 2005). Differentiation of ORNs according to their sensitivity is mainly possible by stimulating ORNs with odors or second messenger analogues (Manzini and Schild, 2003a; Gautam et al., 2006).

Having a closer look at the cAMP-dependent ORN subset, a well known feature of olfactory transduction is the expression of a cascade of two generator channels, a $\mathrm{Ca}^{2+}$-permeable CNG channel driving a $\mathrm{Ca}^{2+}$-dependent $\mathrm{Cl}^{-}$channel (Stephan et al., 2009). The transduction of odorants can be interfered with on three levels: First, at the level of olfactory receptors (Oka et al., 2004a; Oka et al., 2004b; Sanz et al., 2005), second, at the level of receptor potential modulation (e.g. Czesnik et al., 2007 (cannabinoids); Bouvet et al., 1988 (acetylcholine); Kawai et al., 1999 (adrenaline)), and third, at the level of action potential generation. Blocking olfactory transduction at the level of one or the other the generator channel has proven difficult so far, due to the lack of specific $\mathrm{Cl}^{-}$channel blockers and the lack of CNG channel blockers that act at resting membrane potentials.

Obviously, such blockers would be particularly important in order to experimentally dissect the transduction cascade. Furthermore, they would allow systematic pharmacological interference with the cAMP-dependent ORN subset, which is not possible so far. 


\subsection{The effect of endocannabinoids on olfaction}

Olfaction influences the behavior of animals as well as humans. If an olfactory cue is caught a distinct behavioral pattern might be elicited. But also vice versa, the current physiological state has an impact on olfactory processing. E.g. it is everydays experience that olfactory stimuli that are attractive before food intake may become neutral or even aversive afterwards. Even at the most peripheral state of the olfactory system, in the OE, hormones and transmitters modulate processing of odors. Thus, a single ORN cannot be considered as a static unit. Equal inputs may result in varying output, depending on the physiological state of the organism, and thus, the tuning of ORNs.

In the following section I will present a novel mechanism, by which odor responses are affected in a very fascinating way: the cannabinoid modulation. Then I will introduce some endogenous modulatory systems, which are known to exist in the $\mathrm{OE}$ and describe their function. In the last two sections I will give some physiological and biochemical facts about the endocannabinoid system.

\subsubsection{Modulation of olfactory processing in the $\mathrm{OE}$}

\section{Cannabinoids}

The endocannabinoid system is an endogenous signaling system and affects multiple metabolic functions. The name is derived from the cannabis plant Cannabis sativa because of the cannabimimetic actions of its major active compound $\Delta^{9}$-tetrahydrocannabinol, which belongs to the group of cannabinoids (Gaoni and Mechoulam, 1964; Adams and Martin, 1996). The endocannabinoid system comprises cannabinoid (CB) receptors, their endogenous ligands, called endocannabinoids, and the proteins involved in the synthesis and degradation of these ligands (Mackie, 2008; Howlett et al., 2002).

Recently, cannabinoid modulation of olfactory processing was observed. First, CB1 receptor mRNA was detected in the olfactory placodes of Xenopus laevis tadpoles (Migliarini et al., 2006). One year later CB1 receptors could be localized to 
the proximal dendrites of ORNs (Czesnik et al., 2007). They showed that CB1 receptor-specific antagonists modulate odor-evoked $\mathrm{Ca}^{2+}$ changes in ORNs. Responses to odors were reduced and delayed. The delay was up to several seconds, which is an exceptional phenomenon and was not observed for other modulatory systems before. Since the CB1 receptor is expressed in ORNs and since ORNs can be modulated by cannabinoids, the existence of the endocannabinoid system in the OE seems very probable. This raises questions, which were not addressed as yet: Are endocannabinoids produced in the OE and if yes, which is the physiological trigger for endocannabinoid release? Is the odor sensitivity affected by endocannabinoids? And finally, how do endocannabinoids act?

\section{Other modulatory substances}

The modulation of olfactory processing is influenced by hormones involved in energy metabolism, like orexin and leptin. Orexin, an orexigenic peptide, is produced in the hypothalamus and acts on feeding and sleep. Leptin is secreted peripherally by adipocytes and acts in an anorexigenic manner. Additionally, both substances are synthesized locally in the OE (Caillol et al., 2003; Baly et al., 2007). Orexin may modulate transduction via binding to its receptors on ORNs and sustentacular cells (Caillol et al., 2003) and leptin decreases odor-induced transduction currents and receptor potentials upon binding to leptin receptors (Savigner et al., 2009), which are located on a subpopulation of ORNs (Baly et al., 2007). Cerebroventricular injection of orexin results in an increased olfactory sensitivity whereas leptin injection decreases sensitivity (Julliard et al., 2007).

ATP as well as dopamine act in a neuroprotective way in the olfactory system. ATP is thought to be released following noxious stimuli in the OE and reduces odor responsiveness. Vice versa, purinergic receptor antagonists have been shown to increase odor-evoked $\left[\mathrm{Ca}^{2+}\right]_{i}$ transients (Hegg et al., 2003). Dopamine was also postulated to act in a neuroprotective manner in the OE (Hegg and Lucero, 2004; Féron, 1999). Stimulation of dopamine receptors on ORNs modulates hyperpolarization activated currents (Vargas and Lucero, 2002) and voltage-gated $\mathrm{Ca}^{2+}$ channels (Hegg and Lucero, 2004).

Besides the mechanisms described so far, the gonadotropin releasing hormone modulates odor sensitivity in a season-dependent manner (Eisthen et al., 
2000). In addition, the neuroregenerative substances insulin like growth factor (Suzuki and Takeda, 2002; Mathonnet et al., 2001) and neuropeptide Y (Montani et al., 2006) act in the OE.

\subsubsection{Physiological role of the endocannabinoid system}

Appetite stimulation is probably the best-known effect of cannabis use. The ability of the endocannabinoid system to control appetite, food intake and energy balance has recently been described (Matias and Di Marzo, 2007; Osei-Hyiaman et al., 2006; Horvath, 2006). Additionally, selective inverse agonists of CB1 receptors reduce weight and can be used for the treatment of obesity (Kirkham and Tucci, 2006; Engeli, 2008). At the central nervous system level it has been well described that the endocannabinoid system plays a dual role in the regulation of food intake as well as in the homeostatic and non-homeostatic (or hedonic) energy regulation (Matias et al., 2008). Furthermore, it was shown that metabolic functions are controlled by endocannabinoids by acting on peripheral tissues, such as adipocytes, hepatocytes, and the gastrointestinal tract (Pagotto et al., 2006).

Another effect of cannabis consumption is an increased risk of developing a psychosis (Semple et al., 2005). This indicates that a disregulated endocannabinoid system may promote the development of e.g. depression, anxiety or schizophrenia. In fact, the CB1 receptor level in the prefrontal cortex of depressed suicide victims is elevated (Hungund et al., 2004), cannabinoid agonists have an anxiolytic action (Viveros et al., 2005), and schizophrenic patients have an increased CB1 receptor density in various brain regions as well as an increased endocannabinoid level in the cerebrospinal fluid (Zavitsanou et al., 2004; Giuffrida et al., 2004).

Furthermore, endocannabinoids also influence the perception of pain (Richardson et al., 1998), addiction (Scherma et al., 2008), stress (Gorzalka et al., 2008), neuroprotection (Galve-Roperh et al., 2008), and a variety of other functions. 


\subsubsection{Biochemical aspects of the endocannabinoid system}

\section{Cannabinoid receptors}

There are two major receptors which belong to the endocannabinoid system: CB1 and CB2 receptors (Matsuda et al., 1990; Munro et al., 1993). In addition to that, the orphan G protein-coupled receptor GPR55 was recently described to be targeted by a number of cannabinoids (Lauckner et al., 2008). The most abundant CB receptor in the central nervous system is CB1. This suggests that this receptor is responsible for the psychoactive effect of cannabinoids and the physiological actions of endocannabinoids (Elphick and Egertová, 2001).

The CB1 receptor belongs to the family of $G$ protein-coupled receptors (Matsuda et al., 1990) and its distribution was first mapped by using the radiolabeled synthetic cannabinoid $\left[{ }^{3} \mathrm{H}\right] \mathrm{CP} 55,940$. Using current techniques CB1 receptors could be localized in high quantity in the olfactory bulb and the hippocampus, in several parts of the striatum and its target nuclei, and the cerebellar molecular layer. Moderate CB1 receptor levels were identified (Figure 3) in other forebrain regions and in a few nuclei in the brain stem and the spinal cord (Herkenham et al., 1990; Herkenham et al., 1991). The CB1 receptor was also found in peripheral tissues like adipose tissue, liver, skeletal muscle, gastrointestinal tract, pancreas, thyroid gland, and adrenal gland (Pagotto et al., 2006; Demuth and Mollemann, 2006; Juan-Picó et al., 2006).

\section{Endocannabinoids and their metabolism}

The first endocannabinoid which was identified is $N$-arachidonoyl ethanolamide (or anandamide; Devane et al., 1992). It is a partial agonist for both CB receptors (Sugiura et al., 2002). In contrast, 2-arachidonoylglycerol (2-AG), which is found in much higher concentrations than anandamide in the brain (Sugiura et al., 2006), acts as a full agonist at the CB1 and CB2 receptors (Sugiura et al., 2002). Both endocannabinoids are produced on demand. This can be triggered by activation of $\mathrm{G}_{\mathrm{q} / 11}$ protein-coupled receptors, by rising $\left[\mathrm{Ca}^{2+}\right]_{\mathrm{i}}$ to the millimolar range, or by activation of $\mathrm{G}_{\mathrm{q} / 11}$ protein-coupled receptors together with a moderate $\left[\mathrm{Ca}^{2+}\right]_{\mathrm{i}}$ increase (Hashimotodani et al., 2007; Kano et al., 2009). The synthesis pathways (Figure 4) for anandamide and 2-AG are mediated by $N$-acylphosphatidylethanolamide- 

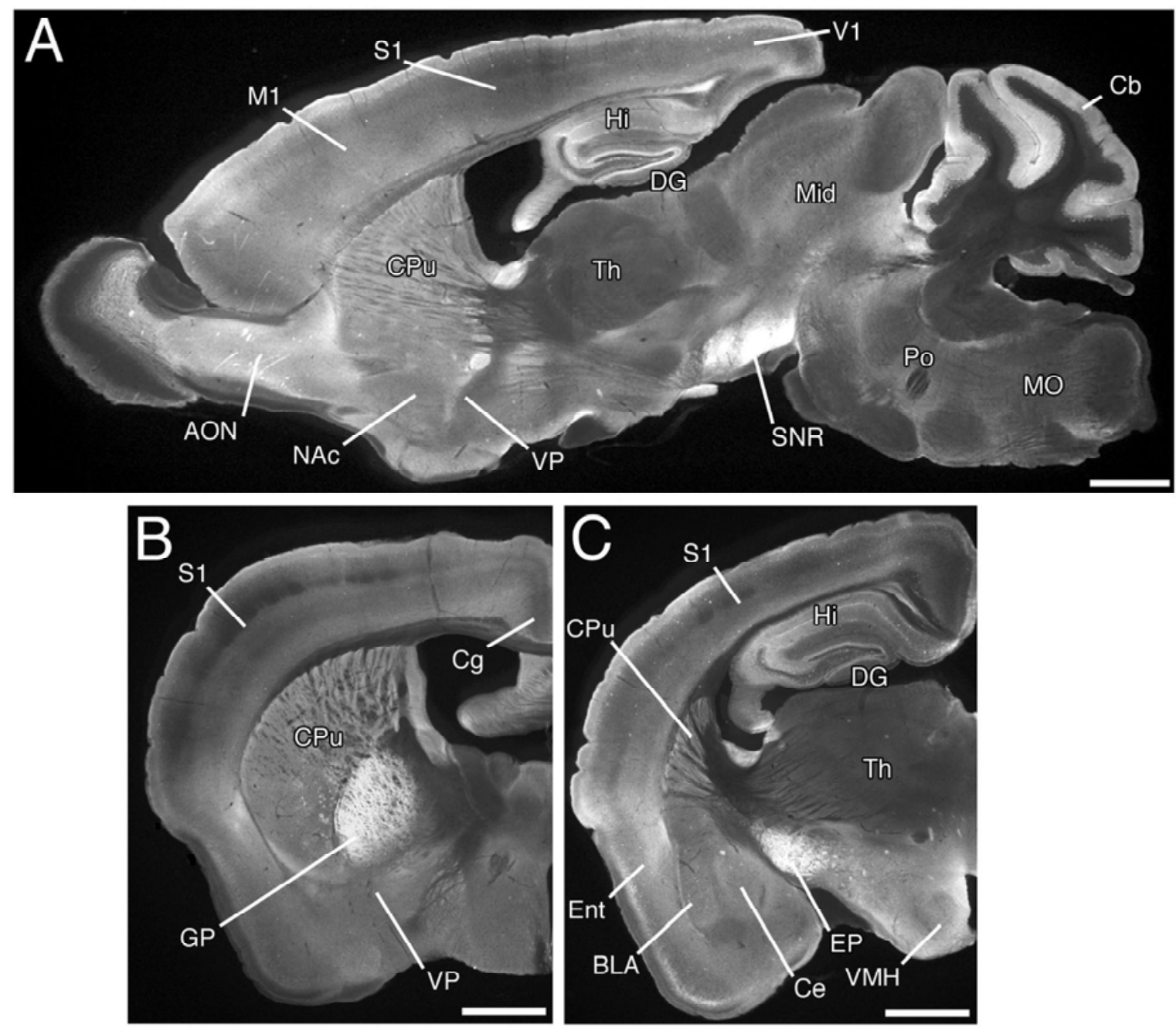

Figure 3: Distribution of $\mathrm{CB} 1$ receptors in the central nervous system. The overall distribution of $C B 1$ receptors in $(A)$ sagittal and $(B, C)$ frontal brain sections of mice was visualized by an immunolabeling with an antibody against the mouse CB1 receptor (Fukudome et al., 2004). CB1 immunoreactivity is highest along striatal output pathways, including the substantia nigra pars reticulata (SNR), globus pallidus (GP), and entopeduncular nucleus (EP). High levels are also observed in the hippocampus ( $\mathrm{Hi})$, dentate gyrus (DG), and cerebral cortex, such as the primary somatosensory cortex (S1), primary motor cortex (M1), primary visual cortex (V1), cingulate cortex (Cg), entorhinal cortex (Ent), basolateral amygdaloid nucleus (BLA), anterior olfactory nucleus (AON), caudate putamen $(\mathrm{CPu})$, ventromedial hypothalamus $(\mathrm{VMH})$, and cerebellar cortex $(\mathrm{Cb})$. Scale bars $1 \mathrm{~mm}$. Figure and figure subtitle modified from Kano et al., 2009. 

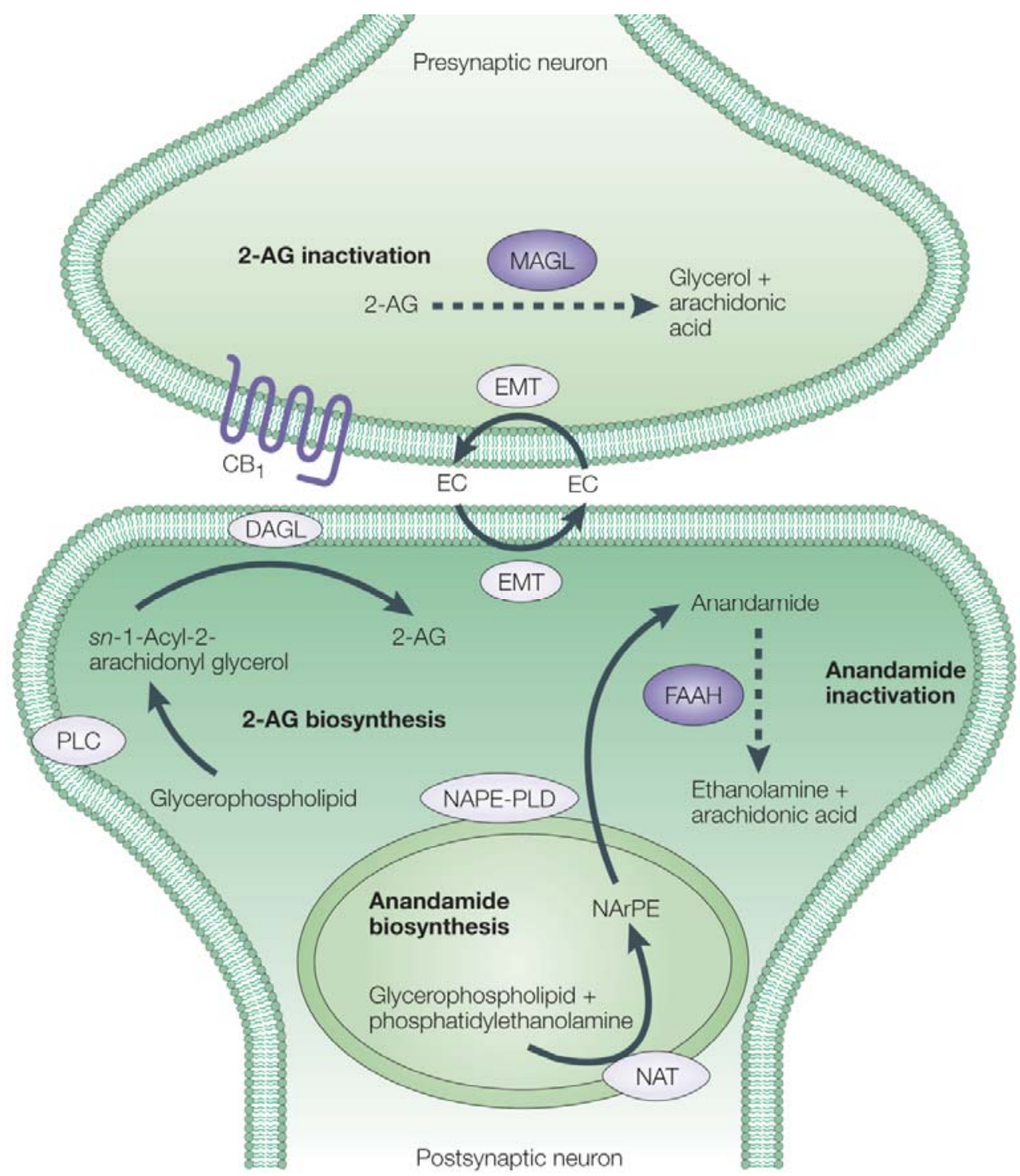

anandamide
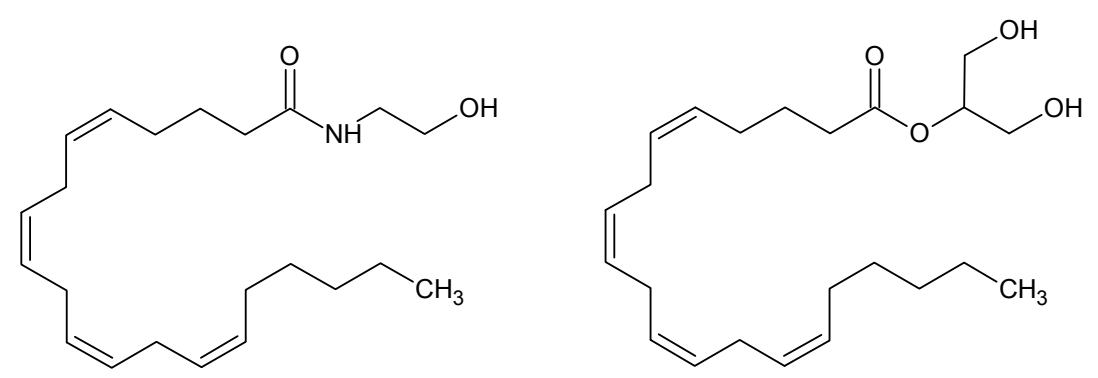

Figure 4: Anabolic and catabolic pathways of anandamide and 2-AG. Both anandamide and 2-AG are arachidonic acid derivates. Anandamide is synthesized by $\mathrm{N}$-acyltransferase (NAT) and NAPE-PLD and degraded by FAAH, 2-AG is produced by phosphorlipase C (PLC) and DAGL and degraded by MAGL. The endocannabinoid membrane transporter (EMT) facilitates endocannabinoid release and uptake. The chemical structures of anandamide and 2-AG are indicated under the scheme. Figure from Di Marzo et al., 2004, see there for further information. 
hydrolyzing phospholipase D (NAPE-PLD) and diacylglycerol lipase (DAGL), respecttively. Both endocannabinoids act extracellularly at CB receptors. For degradation, they are transported into cells, where they are primarily catabolized by the enzymes fatty acid amide hydrolase (FAAH) and monoacylglycerol lipase (MAGL), respectively (Basavarajappa, 2007; Kano et al., 2009).

\section{Endocannabinoid signaling}

Eight years ago, endocannabinoids have been found to act as retrograde messengers. They are released by postsynaptic neurons and modulate the release of inhibitory and excitatory neurotransmitters upon binding to CB1 receptors localized on presynaptic membranes. Besides this well established mechanism of depolarization-induced suppression of inhibition or excitation, endocannabinoids mediate synaptic plasticity and excitability (Kano et al., 2009; Howlett et al., 2004).

The CB1 receptor signaling is very diverse and seems to depend on the identity of the stimulating agonist as well as on the target tissue and the cell type (Howlett et al., 2002; Di Marzo et al., 2004; Demuth and Mollemann; 2006). In the following I will give an overview about the most abundant and best described signaling pathways (Figure 5).

Upon CB1 receptor stimulation, signal transduction pathways involving $\mathrm{G}_{\mathrm{i} / 0}$ or $\mathrm{G}_{\mathrm{S}}$ proteins can be activated (Howlett et al., 2005). Rhee et al. (1998) demonstrated that adenylate cyclase isoforms $1,3,5$, and 8 were inhibited by CB1 receptor activation, and that the subtypes 2, 4, and 7 produced cAMP upon receptor stimulation. The $\mathrm{G}$ proteins coupled to $\mathrm{CB} 1$ receptors mediate a multitude of effects. One important aspect is the modulation of ion channels. Thus, activation of the CB1 receptor may result in the activation of $\mathrm{K}_{\mathrm{ir}}$ and A-type $\mathrm{K}^{+}$channels (McAllister et al., 1999; Childers and Deadwyler, 1996), and in the inhibition of voltage-gated L(Gebremedhin et al., 1999; Straiker et al., 1999), N- (Mackie and Hille, 1992; Huang et al., 2001) and P/Q-type Ca ${ }^{2+}$ channels (Mackie et al., 1995; Hampson et al., 1998). Furthermore, several intracellular kinases, like the protein kinase $A$ and the mitogenactivated protein (MAP) kinase (Bouaboula et al., 1995; Galve-Roperh et al., 2002), are of particular importance for CB1 signaling, because these proteins alter gene expression, which then affects multiple cellular functions. 


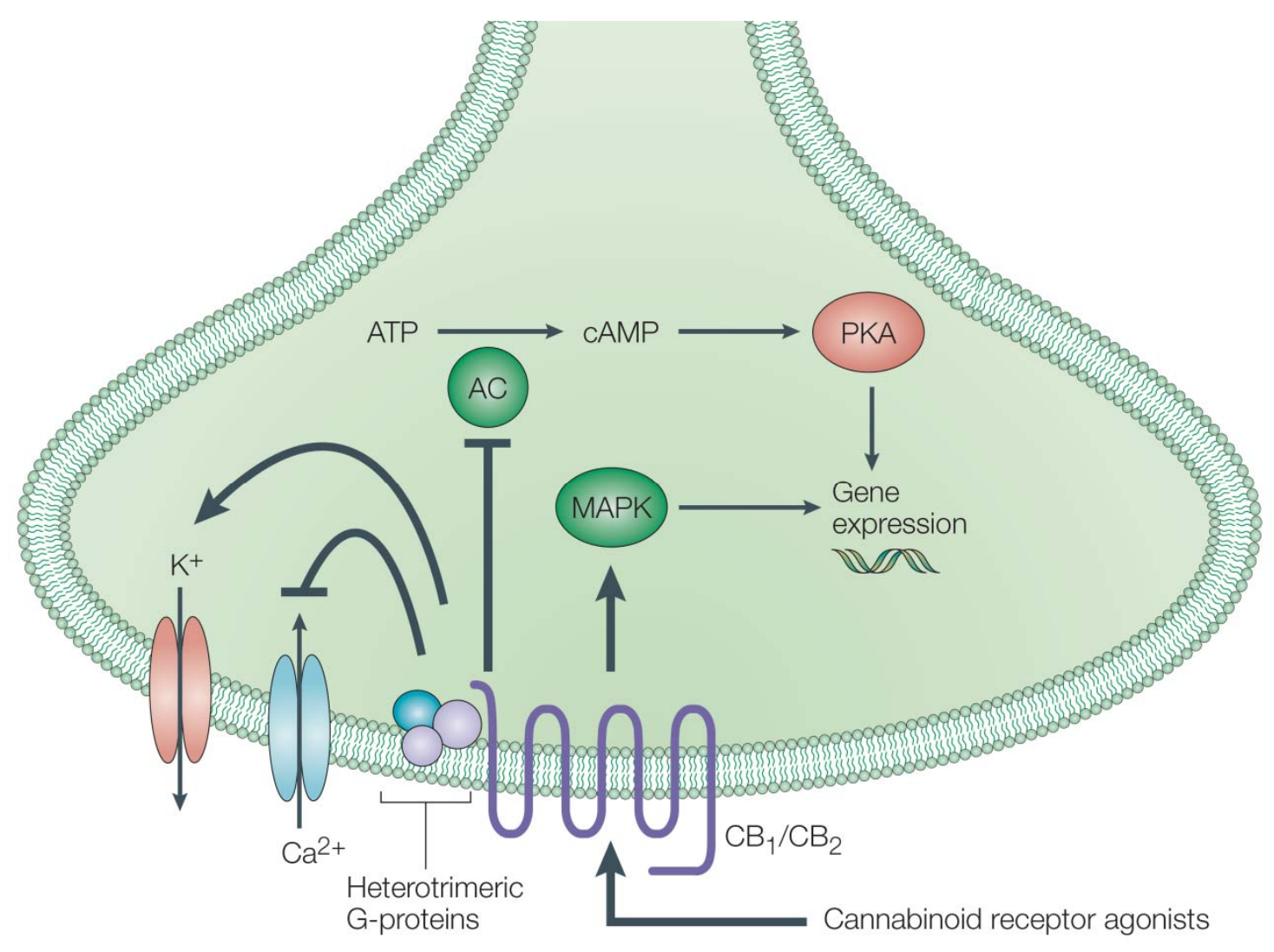

Figure 5: CB1 receptor signaling. The activation of $C B 1$ receptors leads to the stimulation of $G$ proteins that in turn modulate various ion channels. In addition, several intracellular kinases are stimulated, which then modulate gene expression. Note that the figure shows only some of the known intracellular signaling events. Figure from Di Marzo et al., 2004. Abbreviations: AC: adenylate cyclase, PKA: protein kinase A.

What makes signaling of CB1 receptors even more complex is that these receptors form homo- and heterodimers (Mackie, 2005) and that they cross-talk with various other signaling systems, e.g. D2 receptors (Marcellino et al., 2008), opiate receptors (Robledo et al., 2008), and type1 orexin receptors (Hilairet et al., 2003). 


\subsection{Goal of the thesis}

Olfactory disorders are associated with a variety of diseases that can hardly be medicated. In order to establish new drug therapies, it is substantially important to understand the underlying principles of olfaction. This thesis is subdivided into two parts, covering topics of basic research of olfaction:

1. At least two subsets of olfactory receptor neurons exist in the olfactory epithelium regarding odorant transduction mechanisms. One subset transduces odors using the cAMP-dependent transduction cascade, whereas the other subset uses a cAMP-independent transduction mechanism. In order to gain knowledge about, e.g., odor coding mechanisms, it would obviously be important, to be able to interfere with one of these subsets at the level of the generator current. This would make it possible to experimentally dissect the transduction of odors. Recently, the styryl dye FM1-43 was shown to stain olfactory receptor neurons, and to inhibit several cation channels of sensory cells. Therefore, I speculated that FM1-43 might be a promising candidate for blocking olfactory generator channels and examined this hypothesis. In this thesis, it will be shown that only a subset of the olfactory receptor neurons can be labeled with FM1-43. The identity of this subset will be characterized in detail. Furthermore, the effect of FM1-43 on the generator channel of this subset and on odor-induced responses will be examined.

2. The search for food as well as the subsequent food intake is known to be guided by the sense of smell, and it has been suggested that the feeding state modulates the olfactory sensitivity. However, the underlying mechanisms responsible for the functional interaction between olfaction and food intake are as yet poorly understood. It is well-documented that the endocannabinoid system is important for energy homeostasis and nutrition at central stages. The endocannabinoid system may therefore functionally link the feeding state and the olfactory sensitivity of an animal. Indeed, it was recently shown that cannabinoids act on olfactory receptor neurons. In this work, I will detect the endocannabinoid that acts in the olfactory epithelium and the cell types that 
produce this substance. Moreover, the trigger for endocannabinoid release in the olfactory epithelium, the effect on odorant detection thresholds as well as the effector of the cannabinoid receptor will be investigated. Finally, the existence of receptors for other modulatory substances besides endocannabinoids in the olfactory epithelium will be examined. 


\section{Materials and Methods}

\subsection{Xenopus laevis tadpoles as the experimental model}

Xenopus laevis, the South African clawed frog, belongs to the order "Anura" of the amphibians. The natural occurrence of this species is limited to Africa south of the Sahara. Because of its tremendous use as an animal model for many scientific purposes Xenopus laevis now occupies areas all over the world. This frog lives in the mud at the bottom of warm and stagnant water and ponds. It is predominantly crepuscular and nocturnal. The adult Xenopus laevis is counted among the scavengers, whereas the larvae feed mainly on algae. To locate food this species relies mostly on its sense of smell (Avila and Frye, 1978; Nieuwkoop and Faber, 1994).

The olfactory placode of larval animals becomes distinct at stage 23 as a thickening of the sensorial layer of the ectoderm (Klein and Graziadei, 1983). The olfactory organ begins to segregate into the principal cavity and the vomeronasal organ at stage 37/38 (Nieuwkoop and Faber, 1994). Synapses of ORN axons in the olfactory bulb also appear at this stage (Byrd and Burd, 1991). Mature ORNs could be specifically stained and olfactory receptor mRNA could be detected at stage 45 (Hansen et al., 1998). A third sensory chamber, the middle cavity, forms and expands during metamorphosis. At the same time, the principal cavity is remodeled into the principal cavity of the adult animal (Hansen et al., 1998; Nieuwkoop and Faber, 1994).

Since Xenopus laevis is totally aquatic as larva, the principal cavity of the tadpole is exposed to water-borne odorants, and after metamorphosis to airborne odorants. The middle cavity and the vomeronasal organ are always exposed to waterborne odorants (Freitag et al., 1998). The vomeronasal organ detects pheromones (Halpern, 1987). The OE of Xenopus laevis consists of three cell types (Figure 6): ORNs (red), sustentacular cells (green, blue nuclei), and basal cells (blue nuclei shown at the basal side of the OE). Larval animals have ORNs bearing either cilia or microvilli, and sustentacular cells which are either ciliated or secretory. After 


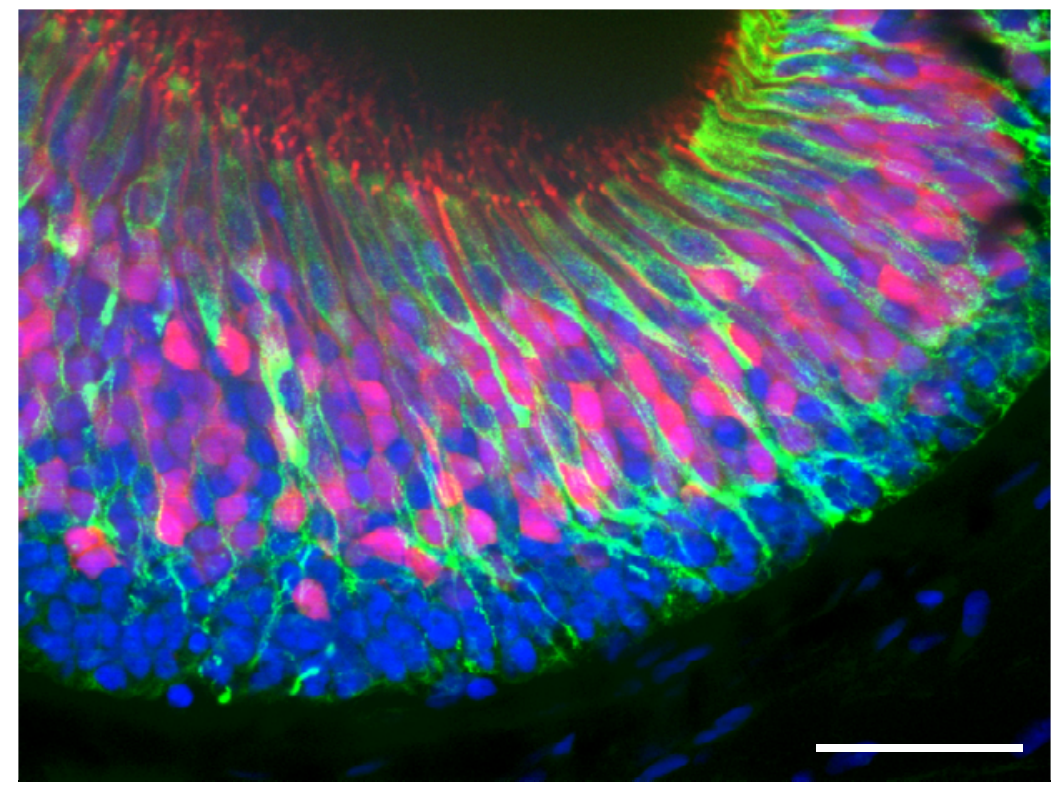

Figure 6: Immunohistochemical staining of the OE of Xenopus laevis larvae. Olfactory receptor neurons in a slice of the OE were stained with a biocytin-streptavidin backtrace (red). In green a cytokeratin-like-immunoreactivity of the sustentacular cells is shown. Sustentacular cells form a tightly packed layer on the apical side of the OE and their processes extend across the OE that terminate in endfeet-like structures at the basal level of the OE. All cell nuclei are stained with DAPI (blue). Scale bar: $15 \mu \mathrm{M}$. Figure kindly provided by $\mathrm{T}$. Hassenklöver.

metamorphosis, the principal cavity comprises only ciliated ORNs and secretory sustentacular cells (Hansen et al. 1998).

In this thesis, Xenopus laevis tadpoles were used as the experimental model, because this aquatic animal is an excellent tool to study the olfactory system. First of all, it is easy to house adult frogs in the laboratory and every six to eight weeks spawning can be induced (Elinson, 2001). Xenopus laevis is a poikilothermal animal, and all experiments can be performed at room temperature. Slice preparations of the olfactory system of the tadpole are easy to produce, because the animals are essentially transparent with only a few melanocytes, and they have no cribriform plate between the OE and the olfactory bulb. 

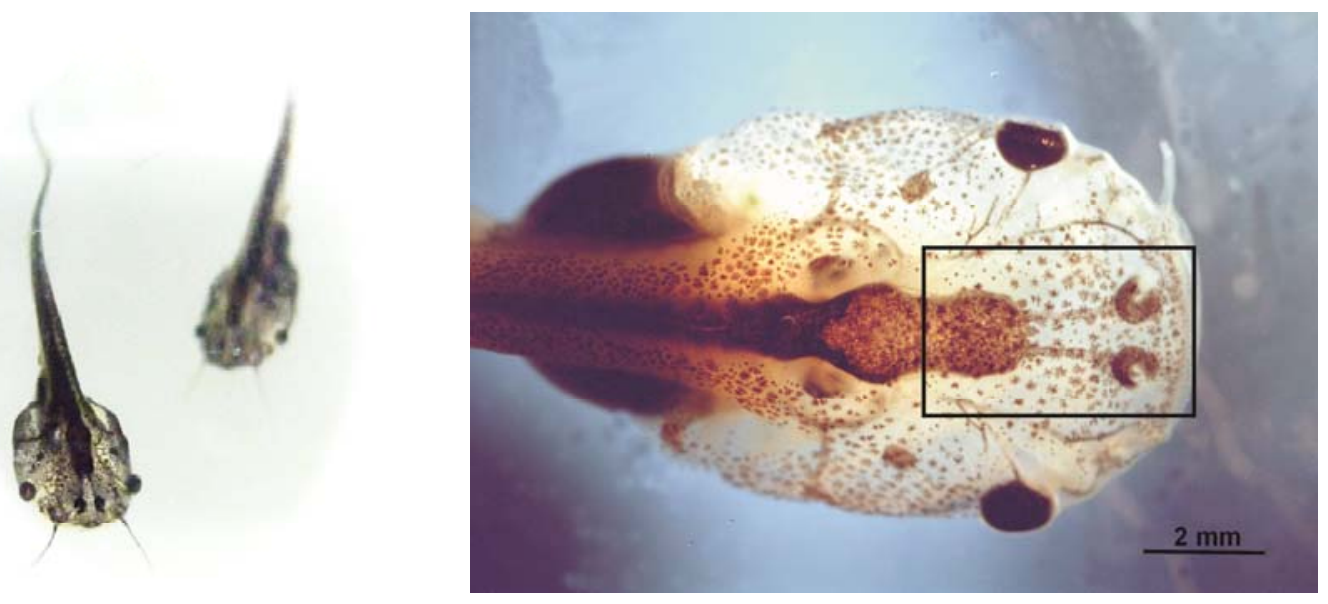

Figure 7: Xenopus laevis tadpole. (A) Larval Xenopus laevis are shown. (B) The olfactory system is marked by a black rectangle. The olfactory mucosa is located most anterior of the head. The ORN axons of the olfactory nerves terminate in the glomeruli in the olfactory bulb, the anterior part of the brain. All tadpoles are from stage 54. Figures kindly provided by T. Hassenklöver and I. Manzini.

Adult frogs were purchased from Kaehler (Hamburg, Germany) and Nasco (USA) and held in aquaria with a water temperature of $20^{\circ} \mathrm{C}$. They were fed with Pondstick food (Tetra Pond, Melle, Germany). For inducing breeding, frogs were separated by gender and repeatedly injected with human chorionic gonadotropin (Sigma, Deisenhofen, Germany) subcutaneously. Then, breeding pairs were housed together overnight, and on the following day the embryos were obtained and kept in separate aquaria (water temperature $20^{\circ} \mathrm{C}$ ). The tadpoles were fed with algae (Dose Aquaristik, Bonn, Germany). For all experiments in this thesis, tadpoles of developmental stages 51 to 54 (Figure 7; Nieuwkoop and Faber, 1994) were used. 


\subsection{In vivo labeling of ORNs with FM1-43}

To stain ORNs with FM1-43 (N-(3-triethylammoniumpropyl)-4-(4-(dibutylamino)styryl)pyridinium dibromide, Figure 8), living tadpoles were transferred into distilled water for $5 \mathrm{~min}$ and then incubated for $7 \mathrm{~min}$ (standard staining) or $1 \mathrm{~min}$ and $15 \mathrm{~s}$ (light staining) in $10 \mathrm{ml} 2 \mu \mathrm{M}$ FM1-43 (Molecular Probes, Leiden, the Netherlands) dissolved in distilled water. Afterwards the tadpoles swam again briefly in distilled water. In some experiments, where the impact of certain substances on the staining efficiency was investigated, $2 \mathrm{mM} \mathrm{CaCl} 2,1 \mathrm{mM} \mathrm{MgCl}_{2}, 200 \mu \mathrm{M} \mathrm{LY}-83,583$ or $1 \mathrm{mM}$ amiloride was added to the solution that contained FM1-43. In these cases the exposure time in the respective incubation solution was $7 \mathrm{~min}$.

Subsequently the animals were anaesthetized for OE slice preparation and viewed by using a laser-scanning confocal microscope attached to an inverted microscope (LSM 510) with 10x or 40x objectives. The confocal pinhole was set to 120-150 $\mu \mathrm{m}$ to exclude fluorescence detection from more than one cell layer. Fluorescence images (excitation at $488 \mathrm{~nm}$; emission > $505 \mathrm{~nm}$ ) of the OE were acquired together with a pseudo bright-field image for orientation in the tissue.

FM1-43 stained tadpoles were also used for OE slice preparation with subsequent double labeling for $\left[\mathrm{Ca}^{2+}\right]_{i}$ imaging experiments.

\subsection{Tissue preparations}

\subsubsection{OE slice preparation}

Slices were prepared of animals, which were prestained with FM1-43 or non-stained. For this purpose, the tadpoles of Xenopus laevis were chilled in a mixture of ice and water and decapitated, as approved by the University of Göttingen Committee for Ethics in Animal Experimentation. A block of tissue containing the OE, the olfactory nerves, and the brain was cut out and kept in bath solution (Table 2). The tissue was then glued onto the stage of a vibratome (VT 1200S; Leica, Bensheim, Germany) and cut horizontally into 130 to $150 \mu \mathrm{m}$ thick slices. 


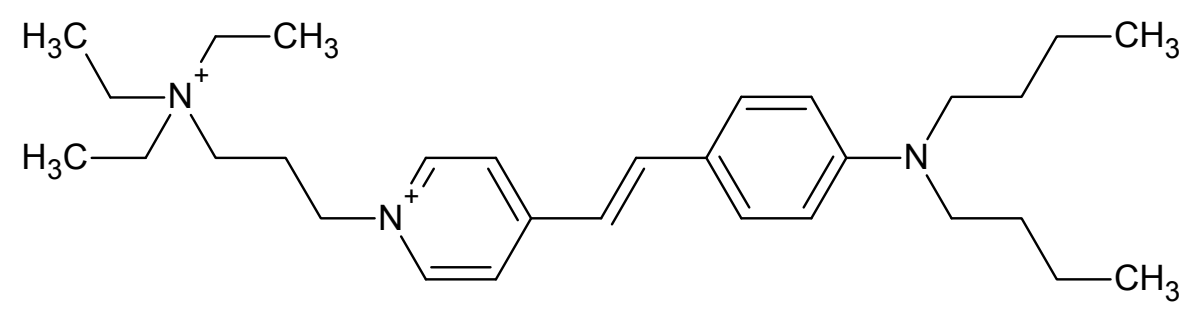

$2 \mathrm{Br}^{-}$

Figure 8: Chemical structure of FM1-43.

For imaging soma $\left[\mathrm{Ca}^{2+}\right]_{\mathrm{i}}$, tissue slices were incubated with $200 \mu \mathrm{l}$ of bath solution containing $50 \mu \mathrm{M}$ fluo-4 AM (Molecular Probes, Leiden, The Netherlands) and $50 \mu \mathrm{M}$ MK571 (Alexis Biochemicals, Grünberg, Germany). Fluo-4 AM was dissolved in DMSO (Sigma, Deisenhofen, Germany) and Pluronic F-127 (Molecular Probes). The final concentrations of DMSO and Pluronic F-127 did not exceed $0.5 \%$ and $0.1 \%$, respectively. To avoid multidrug resistance transporter mediated destaining of the slices, MK571, a specific inhibitor of the multidrug resistance-associated proteins, was added to the incubation solution (Manzini et al., 2003b). After incubation at room temperature for $30 \mathrm{~min}$, the tissue slices were put under a grid in a recording chamber and placed on the microscope stage of an Axiovert 100M (Zeiss, Jena, Germany) to which a laser scanning unit (LSM 510; Zeiss) was attached. Before starting the $\mathrm{Ca}^{2+}$ imaging experiments, the slices were rinsed with bath solution for at least $5 \mathrm{~min}$.

\subsubsection{Olfactory bulb whole mount preparation}

For imaging $\left[\mathrm{Ca}^{2+}\right]_{\mathrm{i}}$ of glomeruli, ORNs were traced via fluo-4 dextran $10 \mathrm{kDa}$ by electroporation in the OE. For this purpose, larval Xenopus laevis were anesthetized in $0.02 \%$ MS-222 (Sigma). Crystals of fluo-4 dextran, potassium salt, $10 \mathrm{kDa}$ 
(Invitrogen) were inserted into the nasal cavities, where it dissolved in the residual water. Subsequently, two platinum electrodes of $250 \mu \mathrm{m}$ diameter and $3 \mathrm{~mm}$ interspace interval were placed into the nasal cavities and the dye was electroporated by application of $30 \mathrm{~V}$ twelve times with alternating polarity. The animals were kept in a water tank for one to three days until experiments were performed.

Tadpoles were chilled in a mixture of ice and water and decapitated, as approved by the University of Göttingen Committee for Ethics in Animal Experimentation. A block of tissue containing the $\mathrm{OE}$, the olfactory nerves, and the brain was cut out and kept in bath solution (Table 2). The tissue surrounding the ventral part of the olfactory bulb was removed and the whole-mount preparation was put under a grid in a recording chamber and placed on the microscope stage of an Axiovert 100M (Zeiss, Jena, Germany) to which a laser scanning unit (LSM 510; Zeiss) was attached. The tissue was rinsed with bath solution for at least $5 \mathrm{~min}$ before the experiment was started.

\subsection{Conventional and advanced $\left[\mathrm{Ca}^{2+}\right]_{\mathrm{i}}$ imaging and patch clamp recordings}

\subsection{1 $\left[\mathrm{Ca}^{2+}\right]_{\mathrm{i}}$ imaging of odor-induced responses of ORNs and glomeruli with confocal microscopy}

For $\left[\mathrm{Ca}^{2+}\right]_{i}$ imaging of odor-induced responses of ORNs, fluo-4 stained tissue slices were produced. Glomeruli were imaged using whole mount preparations prestained with fluo-4 dextran.

$\left[\mathrm{Ca}^{2+}\right]_{i}$ was monitored using a laser-scanning confocal microscope (LSM 510, Zeiss). The confocal pinhole was set to approximately $120 \mu \mathrm{m} / 300 \mu \mathrm{m}$ to exclude fluorescence detection from more than one cell layer / glomerulus. Fluorescence images (excitation at $488 \mathrm{~nm}$; emission > $505 \mathrm{~nm}$ for fluo-4 stained OE slices and glomeruli; emission from 505 to $530 \mathrm{~nm}$ and > $560 \mathrm{~nm}$ for fluo-4 and FM1-43 doublestained OE slices, respectively) of the OE were acquired in the range of 1.02 to $2.03 \mathrm{~Hz}$, with three to ten images taken as control images before the onset of odor 
delivery. The fluorescence changes $\Delta F / F$ of fluo-4 were calculated for individual ORNs / glomeruli as $\Delta F / F=\left(F_{1}-F_{2}\right) / F_{2}$, where $F_{1}$ was the fluorescence averaged over the pixels of an ORN soma / glomerulus, while $F_{2}$ was the average fluorescence of the same pixels prior to stimulus application, averaged over five images. A response was assumed if the following two criteria were met: (i) the first two intensity values after stimulus arrival at the mucosa, $\Delta F / F\left(t_{1}\right)$ and $\Delta F / F\left(t_{2}\right)$, had to be larger than the maximum of the prestimulus intensities; (ii) $\Delta F / F\left(t_{2}\right)>\Delta F / F\left(t_{1}\right)$ with $t_{2}>t_{1}$. Data analysis was performed with Matlab (Mathworks, USA).

\subsubsection{Uncaging of cAMP in ORNs viewed with confocal microscopy}

In order to observe the effect of cAMP uncaging on $\left[\mathrm{Ca}^{2+}\right]_{i}$ in FM1-43-loaded ORNs, tadpoles were stained with the dye as described and OE slices were prepared. Afterwards the tissue was incubated in $200 \mu \mathrm{l}$ of $\mathrm{Ca}^{2+}$ indicator rhod-2 AM solution (50 $\mu \mathrm{M}$ rhod-2 AM (Molecular Probes, Leiden, The Netherlands) dissolved in DMSO $(0.5 \%)$ and Pluronic F-127 (0.1\%) and $50 \mu \mathrm{M}$ MK571) at room temperature for $30 \mathrm{~min}$. The tissue slices were placed under a grid in a recording chamber and positioned on the microscope stage of an Axiovert 100M to which a laser scanning unit was attached. A glass fiber (HCG-M0200T $200 \mu \mathrm{m}$, Laser Components) coupled to a $378 \mathrm{~nm}$ diode laser (iPulse, Toptica Photonics) was positioned next to the OE. The slices were incubated with $100 \mu \mathrm{M}$ DMNB-caged cAMP (Invitrogen, stock solution: $20 \mathrm{mM}$ in DMSO) for $15 \mathrm{~min}$. Stimulation of ORNs was performed by a $10 \mathrm{~ms}$ laser pulse ( $378 \mathrm{~nm}, 16 \mathrm{~mW})$.

After FM1-43-loaded ORNs were identified, rhod-2 fluorescence was monitored using a pinhole diameter of approximately $120 \mu \mathrm{m}$. Images (excitation at $543 \mathrm{~nm}$; emission > $560 \mathrm{~nm}$ ) of the OE were acquired in the range of 1.02 to $2.03 \mathrm{~Hz}$, with three to ten images taken as control images before the onset of odor delivery. The fluorescence changes $\Delta F / F$ were calculated for individual ORNs. Data analysis was performed with Matlab. 


\subsection{3 $\left[\mathrm{Ca}^{2+}\right]_{i}$ dendrite imaging in tissue slices with a fast scanning line illumination microscope}

For fast imaging of dendrite $\left[\mathrm{Ca}^{2+}\right]$, slices were placed under a grid in a recording chamber and viewed by a $63 x$ water immersion objective mounted to a custom-built line illumination microscope described by Junek et al. (2009). Patch pipettes were filled with $4 \mu \mathrm{l}$ fluo-4 containing pipette solution (Table 3). After establishing the whole-cell mode fluo-4 diffused into the cell. Subsequently, stacks of images of the stained ORN were obtained every $30 \mathrm{~s}$. Each image stack comprised 20 images and was acquired within $328 \mathrm{~ms}$.

\subsubsection{Patch-clamp recordings of the CNG current}

For patch-clamping the slices were placed under a grid in a recording chamber and viewed by using Nomarski optics (Axioskop 2; Zeiss, Göttingen, Germany). Patch pipettes with a tip resistance of 6-10 $\mathrm{M} \Omega$ were pulled from borosilicate glass with a $1.8 \mathrm{~mm}$ outer diameter (Hilgenberg, Malsfeld, Germany) by a two-stage pipette puller (PC-10, Narishige, Japan) and filled with $4 \mu \mathrm{l}$ CAMP and cGMP containing pipette solution (Table 3). Pulse protocols for data acquisition were written in C. Voltage pulses were delivered from a microcontroller (Schild et al., 1996) to a D/A converter and then to the patch-clamp amplifier (EPC7; List, Darmstadt, Germany) in order to assess the impedance in the on-cell and whole-cell configurations. The data were digitized online.

After establishing the on-cell configuration in bath solution the holding potential was set to $0 \mathrm{mV}$. The responsiveness of the patch-clamped cell was tested by stimulating the ORN with $50 \mu \mathrm{M}$ forskolin dissolved in bath solution. Subsequently, the holding potential was set to $-70 \mathrm{mV}$ and the external solution was replaced by $\mathrm{Ca}^{2+}$ and $\mathrm{Mg}^{2+}$ free bath solution (Table 2) with or without $10 \mu \mathrm{M}$ FM1-43. Directly after establishing the whole-cell configuration by shortly applying negative pressure to the patch pipette an inward current was induced. Evaluation of the current traces was performed in Matlab. 


\subsubsection{Bathing conditions and stimulus application}

For all experiments the recording chamber was perfused by gravity feed from a syringe through a funnel applicator (Schild, 1985; Manzini et al., 2002) with various bath solutions (Table 2). The tip of the applicator was placed in front of the OE. The change of the external solution was performed by stopping the influx of one bath solution and starting the influx of another bath solution into the funnel applicator.

A mixture of amino acids (Manzini et al., 2002; Caprio and Byrd, 1984; lida and Kashiwayanagi, 1999), amines (Carr and Derby, 1986; Carr et al., 1990; Rolen et al., 2003; Gliem et al., 2009), bile acids (Kang and Caprio, 1995; Sato and Suzuki, 2001) and alcohols (Altner et al., 1977; Tinsley and Kobel, 1996) are known to be odorants for aquatic species and were used as odors. A mixture of 19 amino acids or single amino acids (arginine, lysine and methionine), as well as mixes of amines, bile acids, and alcohols were used as odors. The odors were dissolved in bath solution (stocks of $10 \mathrm{mM}$ or $25 \mathrm{mM}$, see Table 4) and used at a final concentration of $0.2 \mu \mathrm{M}$ to $100 \mu \mathrm{M}$ in all of the experiments. Stimulus solutions were prepared immediately before use and were pipetted directly into the funnel for bath perfusion without stopping the flow. Outflow was through a syringe needle placed close to the OE. The time course of stimulus arrival at the OE was simulated by applying the fluorescent dye avidin AlexaFluor-488 as a dummy stimulus and by measuring the fluorescence after avidin AlexaFluor-488 application to the funnel. The delay of stimulus arrival caused by the syringe, i.e., from pipetting into the funnel to concentration increase in the OE, was approximately $2 \mathrm{~s}$. The minimum interstimulus interval between odorant applications was 2 min.

\subsection{Molecular biology experiments}

\subsubsection{Single-cell reverse transcription (RT) PCR}

Tissue slices were visualized using a 40x water immersion objective mounted to an Axioscop 2 microscope. Patch pipettes were filled with $4 \mu$ pipette solution (Table 3 ). 
Cells were identified as ORNs and sustentacular cells based on their morphology. After the formation of a gigaseal, negative pressure was applied to the pipette and the whole cell configuration was established (Hamill et al., 1981). Olfactory receptor neurons showed spontaneous spiking activity in the on-cell mode and typical voltagegated $\mathrm{Na}^{+}$and $\mathrm{K}^{+}$currents in the whole cell configuration. Sustentacular cells typically show no electric activity. Cell cytoplasm was harvested under visual and resistance control by applying gentle suction to the patch pipette.

Cells fulfilling these physiological criteria and whose seals remained intact during harvesting were used for reverse transcription with a modified protocol of the SuperScript ${ }^{\mathrm{TM}}$ III First-Strand Synthesis System for RT PCR (Invitrogen). The content of the pipette was immediately expelled into a tube containing $5 \mathrm{ng}$ random hexamers, $40 \mathrm{U}$ RNasin Plus RNase Inhibitor (Promega), $1 \mathrm{mM}$ dNTP mix, and DEPC water. The mixture was heated to $65{ }^{\circ} \mathrm{C}$ for $5 \mathrm{~min}$ and cooled on ice for at least 1 min. Next, reverse transcription was performed by adding 1x RT buffer, $5 \mathrm{mM} \mathrm{MgCl}_{2}$, $10 \mathrm{mM}$ DTT, $2 \mathrm{U}$ RNaseOUT, and $10 \mathrm{U}$ SuperScript III RT and incubating in a thermocycler (T-Personal, Biometra) at $25^{\circ} \mathrm{C}(10 \mathrm{~min}), 50^{\circ} \mathrm{C}(50 \mathrm{~min}), 85^{\circ} \mathrm{C}(5 \mathrm{~min})$, and chilled on ice. RNA was degraded by adding $1 \mu \mathrm{l}$ RNase $\mathrm{H}$ and incubating for $20 \mathrm{~min}$ at $37{ }^{\circ} \mathrm{C}$. Negative control reactions without SuperScript III RT were also performed.

The cDNA produced in one single cell RT was split in four tubes and served as the template for PCR. The reactions were performed according to the manual of the FastStart Taq DNA Polymerase (Roche). In brief, the reaction mix contained $200 \mathrm{nM}$ specific forward and reverse primers for OMP1 (Rössler et al., 1998), CYTII, DAGLa, or DAGL $\beta$ (primer sequences in Table 1), $200 \mu \mathrm{M}$ dNTPs, 1x PCR buffer, and $2 \mathrm{U}$ FastStartTaq DNA Polymerase. The reaction was activated at $95{ }^{\circ} \mathrm{C}$ for $5 \mathrm{~min}$ and underwent 40 cycles of a temperature protocol of $30 \mathrm{~s}$ at $95{ }^{\circ} \mathrm{C}, 30 \mathrm{~s}$ at $58{ }^{\circ} \mathrm{C}$, and $45^{\circ} \mathrm{C}$ at $72{ }^{\circ} \mathrm{C}$. After a final extension of $7 \mathrm{~min}$ at $72{ }^{\circ} \mathrm{C}$ the PCR products were run on a $2 \%(\mathrm{w} / \mathrm{v})$ agarose gel in tris acetate EDTA (TAE) buffer containing ethidium bromide (Sigma) and visualized under UV-light (UVsolo, Biometra). 


\subsubsection{Real-time PCR}

Tadpoles were exposed to four different nutritious states $(n=7)$ : In one condition animals were food-deprived for $6 \mathrm{~h}$ (group $A_{6 h}$ ) or $12 \mathrm{~h}$ (group $A_{12 h}$ ) in another animals were food-deprived for $6 \mathrm{~h}$ and overfeed for $2 \mathrm{~h}$ with $1 \mathrm{~g}$ shredded algae (Dohse Aquaristic, Millipore; group $\mathrm{B}_{6 \mathrm{~h}}$ ) per $1 \mathrm{I}$ water or $12 \mathrm{~h}$ food-deprived for $12 \mathrm{~h}$ and overfeed for $2 \mathrm{~h}$ (group $\mathrm{B}_{12 \mathrm{~h}}$ ). As control condition animals were overfeed for $2 \mathrm{~h}$ (group C).

\section{RNA isolation and cDNA synthesis}

Olfactory epithelia of four animals per condition were cut out of the tissue and stored in liquid nitrogen until RNA isolation. Total RNA was isolated with the TRIzol method (Invitrogen) according to the manufacturer's protocol and DNA-contaminations were removed by subsequent DNase I treatment (DNase I recombinant, RNase-free, Roche). The RNA quality and quantity was analyzed with the microfluidics-based electrophoresis system Agilent 2100 Bioanalyzer (Agilent Technologies). Reverse transcription was performed from $1 \mu \mathrm{g}$ RNA with the iScript cDNA Synthesis Kit from BioRad as described in the manual.

\section{cDNA Quantification}

Quantification of DAGL $\alpha$ and $\beta$ RNA was performed using the $\mathrm{iQ} \mathrm{SYBR}$ Green Supermix (BioRad) on an iQ5 real-time PCR detection system (BioRad) according to the manufacturer's instructions. The ATPase $F_{0} F_{1}$ (primer sequences see Table 1) was used as an internal control. The general PCR conditions were as follows: polymerase activation at $98^{\circ} \mathrm{C}$ for $30 \mathrm{~s}$ followed by 40 cycles of denaturation at $94{ }^{\circ} \mathrm{C}$ for $1 \mathrm{~s}$, annealing at $58{ }^{\circ} \mathrm{C}$ for $15 \mathrm{~s}$, and extension at $72{ }^{\circ} \mathrm{C}$ for $1 \mathrm{~s}$. After the amplification a melt curve analysis verified the formation of the single desired PCR products. The relative gene expression ratios (Kubista et al., 2006) were determined and normalized for control conditions. Confidence intervals were calculated by determining the standard deviation of the logarithmized ratios followed by exposing the left and right borders. 


\subsubsection{Conventional PCR}

For the analysis of gene expression of Xenopus laevis, Rattus norvegicus and Homo sapiens mRNA was analyzed. The OEs of three rats were excised. For Xenopus laevis tadpoles, ten OEs were pooled for all three samples. mRNA isolation and reverse transcription were accomplished as described. Human cDNA was kindly provided by Thomas Hummel. For PCR, $200 \mathrm{ng}$ of cDNA were mixed with PCR buffer, $200 \mu \mathrm{M}$ nucleotide mix, $200 \mathrm{nM}$ forward and reverse primers (Table 1), and 2 U FastStartTaq DNA Polymerase dissolved in PCR grade water as described in the manual (FastStart Taq DNA Polymerase, dNTPack, Roche, Mannheim, Germany). The samples were incubated in a thermocycler with the following PCR conditions: polymerase activation at $95{ }^{\circ} \mathrm{C}$ for $5 \mathrm{~min}$ followed by 30 cycles of denaturation at $95{ }^{\circ} \mathrm{C}$ for $30 \mathrm{~s}$, annealing at $56{ }^{\circ} \mathrm{C}$ for $30 \mathrm{~s}$, and extension at $72{ }^{\circ} \mathrm{C}$ for $45 \mathrm{~s}$. After a final elongation at $72{ }^{\circ} \mathrm{C}$ for 7 min PCR products were run on a $2 \%$ agarose gel in TAE buffer and ethidium bromide and visualized under UV light. 


\begin{tabular}{|c|c|c|c|}
\hline & forward primer & reverse primer & $\begin{array}{c}\text { product } \\
\text { length [bp] }\end{array}$ \\
\hline \multicolumn{4}{|c|}{ Xenopus laevis } \\
\hline OMP1 & СTTTCTTAGATGGCGCTGACC & GTGGTTATTTCTCTACACTTGG & 404 \\
\hline CYTII & CATTGATAAGGTCAGGTTCCTG & CACGGAGTTCAGCTTCATAC & 389 \\
\hline $\mathrm{F}_{0} \mathrm{~F}_{1}$ & GTCAGCGTGAGCTCATCATC & GCATCAGAGGCTGTAGCAGA & 161 \\
\hline CB1 & TCCTACCACTTCATTGGCAGCTT & TCCATGCGAGTCTGGTCC & 560 \\
\hline DAGL $\alpha$ & GTCATGGTGAGTCCGACAGAG & TTTGAGAATTGGCGACAGAAG & 210 \\
\hline DAGL $\beta$ & ATGACCTGGTGTTTCCTGGAG & ACACAATGGCAGAGACCACAC & 186 \\
\hline NAPE-PLD & TAGCAATGTTCCCAGCTCAAA & TGAAGCTTATTGGGGAAGCAT & 209 \\
\hline FAAH & ATGGAGTGCCGATTACCCTAA & TGTCCAAAGATGGAATTGCTG & 205 \\
\hline MAGL & AACACTGCTGCCGATATGATG & GGTCCGGGTATTGTTTCTTCA & 183 \\
\hline $\mathrm{D} 2 \mathrm{~A}$ & GCCGCTGCTTTACAAGATTC & ACCGGTAGATCCACAACTGC & 378 \\
\hline D2B & CCAGTGCAACAATGTCAACC & AAGCCAAGTGAAGGCACTGT & 319 \\
\hline AdR1 & GGCATTTCCAACCTTCAAGA & AAGGGGGCTAGTGGATCAGT & 159 \\
\hline AdR2 & AGATTGGGTGGCTGGTACTG & GAATTCCTGGAGGTTGGACA & 188 \\
\hline leptinR & САCATGCCTCCTGCACTTAT & TGCTGCTGTCTGAACTCACC & 249 \\
\hline \multicolumn{4}{|c|}{ Rattus norvegicus } \\
\hline CB1 & TCTGATCCTGGTGGTGTTGA & TGTCTCAGGTCCTTGCTCCT & 180 \\
\hline DAGL $\alpha$ & TACCTGGGCATCCTTCTGAG & GACCATCCCGAGAGTGACAT & 234 \\
\hline DAGL $\beta$ & CCACGTTAGCTTTCACGACA & ACGCAGTCCTGTAGCTCGAT & 174 \\
\hline NAPE-PLD & АСССТCCTGGATGACAACAA & TCTGGGTCAGCATGTTGGTA & 203 \\
\hline FAAH & GTGGAAACTGCAGCATGAGA & CTGAGCCAGACTCCAAGGAC & 204 \\
\hline MAGL & GACCTTCCTCACCTGGTCAA & TGGAAGTCCGATACCACCAT & 230 \\
\hline CB2 & АTCTTTGCCTGCAACTTCGT & GTAGGAGATCAACGCCGAGA & 243 \\
\hline GPR55 & СТСССТСССАТTСААGАTGA & ATGCTTCCAACCCATACCAG & 240 \\
\hline D2 & TCCCAGCAGAAGGAGAAGAA & CGGAACTCGATGTTGAAGGT & 212 \\
\hline AdR1 & ACGGCTCATCTACCTCTCCA & GACAAAGCCCTCAGCGATAG & 175 \\
\hline AdR2 & CTCATGATGTGCTGCCAGAT & GAAGAACAACCCGAAGACCA & 245 \\
\hline
\end{tabular}




\begin{tabular}{|c|c|c|c|}
\hline orexinR1 & GAGTTCCTCCGCTACCTGTG & CATGATTCGGTGATGTCCAC & 248 \\
\hline orexinR2 & TTCCCGGAACTTCTTCTGTG & GTGTGTGAACATCCCGAACA & 242 \\
\hline leptinR & TGCAGTGTACTGCTGCAATG & CTGCACAGTGCTTCCCACTA & 166 \\
\hline \multicolumn{4}{|c|}{ Homo sapiens } \\
\hline CB1 & AAGACCCTGGTCCTGATCCT & CGCAGGTCCTTACTCCTCAG & 188 \\
\hline DAGL $\alpha$ & AGAATGTCACCCTCGGAATG & GGTTGTAGGTCCGCAGGTTA & 197 \\
\hline DAGL $\beta$ & TGCCACAGTGGTTTCCATTA & CAACCCGAGTATGGTCGTCT & 203 \\
\hline NAPE-PLD & AGCTATTCCCATCGGAGCTT & TCAGCTTCACTGGAGGCTCT & 173 \\
\hline FAAH & AAGGGACCAACTGTGTGACC & CATGGACTGTGGAACATTGG & 248 \\
\hline MAGL & ATGTGTTGCAGCATGTGGAT & AAGAACCAGAGGCGAAATGA & 155 \\
\hline CB2 & CGTGGCTGTGCTCTATCTGA & CACAGAGGCTGTGAAGGTCA & 211 \\
\hline GPR55 & AAGAACCCACAGACCAGGTG & СТСТGCCCAAGACACTСТСС & 217 \\
\hline D2 & CACCTGAGGGCTCCACTAAA & САTGCCCATTCTTCTCTGGT & 202 \\
\hline AdR1 & CTTGACCATGCTCAGACCAA & GGGACAAAGCTCCCCATAAT & 207 \\
\hline AdR2 & TGGGAAGTTTTGTTCCTTGG & TTAAGGAACCCCTCCGAGAT & 180 \\
\hline orexinR1 & GAGGAAGACAGCCAAGATGC & ATGGGCAGGACAGAGCTAGA & 245 \\
\hline orexinR2 & ATTTGGGATGTTTGCCCATA & ATGGTGAACTCCAAGGCAAC & 178 \\
\hline leptinR & СTCCATCCAGTGTGAAAGCA & TAGCCTCTTACAGCGCACCT & 233 \\
\hline
\end{tabular}

Table 1: Primer sequences. All sequences listed are written from 5' to 3'. The resulting length of the PCR products are indicated in base pairs (bp). All primers were purchased from Invitrogen. Abbreviations of gene names: OMP1: olfactory marker protein 1, CB1: CB1 receptor, D2A and $B$ : dopamine receptor $2 A$ and $B, A d R 1$ and 2: adiponectin receptor 1 and 2, leptinR: leptin receptor, CB2: CB2 receptor, GPR55: G protein-coupled receptor 55, orexinR1 and 2: orexin receptor 1 and 2. 


\subsection{Solutions}

\subsubsection{External solutions}

\begin{tabular}{lccccc}
\hline & bs & 0 Ca 0 Mg & NMDG25 & NMDG10 & NMDG0 \\
\hline $\mathrm{NaCl}$ & $98 \mathrm{mM}$ & $98 \mathrm{mM}$ & $25 \mathrm{mM}$ & $10 \mathrm{mM}$ & $0 \mathrm{mM}$ \\
$\mathrm{NMDG}$ & - & - & $73 \mathrm{mM}$ & $88 \mathrm{mM}$ & $98 \mathrm{mM}$ \\
$\mathrm{KCl}$ & $2 \mathrm{mM}$ & $2 \mathrm{mM}$ & $2 \mathrm{mM}$ & $2 \mathrm{mM}$ & $2 \mathrm{mM}$ \\
$\mathrm{CaCl}_{2}$ & $1 \mathrm{mM}$ & - & $1 \mathrm{mM}$ & $1 \mathrm{mM}$ & $1 \mathrm{mM}$ \\
$\mathrm{MgCl}_{2}$ & $2 \mathrm{mM}$ & - & $2 \mathrm{mM}$ & $2 \mathrm{mM}$ & $2 \mathrm{mM}$ \\
glucose & $5 \mathrm{mM}$ & $5 \mathrm{mM}$ & - & - & - \\
sodium pyruvate & $5 \mathrm{mM}$ & $5 \mathrm{mM}$ & - & - & - \\
HEPES & $10 \mathrm{mM}$ & $10 \mathrm{mM}$ & $10 \mathrm{mM}$ & $10 \mathrm{mM}$ & $10 \mathrm{mM}$ \\
EGTA & - & $2 \mathrm{mM}$ & - & - & - \\
\hline
\end{tabular}

Table 2: Composition of external solutions. The composition of all bath solutions used are listed in this table. All components were purchased from Sigma. Abbreviations: bs: bath solution, 0 Ca $0 \mathrm{Mg}$ : $\mathrm{Ca}^{2+}$ and $\mathrm{Mg}^{2+}$ free bath solution, NMDG25/10/0: bath solution with substituted $\mathrm{Na}^{+}$(25/10/0 $\mathrm{mM} \mathrm{Na}^{+}$and 73/88/98 mM NMDG, a Na ${ }^{+}$substitute). 


\subsubsection{Internal solutions}

Stock solutions for $\mathrm{Na}_{2}$-ATP (100 mM), Na - GTP (10 mM), CAMP (100 mM), and cGMP (10 mM) were prepared in HEPES solution ( $\mathrm{pH} 7.8)$, fluo-4 potassium salt was dissolved in distilled water (10 $\mathrm{mM})$.

\begin{tabular}{lccc}
\hline & ps & cAMP/cGMP ps & fluo-4 ps \\
\hline $\mathrm{NaCl}$ & $2 \mathrm{mM}$ & $2 \mathrm{mM}$ & $2 \mathrm{mM}$ \\
$\mathrm{KCl}$ & $11 \mathrm{mM}$ & $11 \mathrm{mM}$ & $11 \mathrm{mM}$ \\
$\mathrm{MgSO}_{4}$ & $2 \mathrm{mM}$ & $2 \mathrm{mM}$ & $2 \mathrm{mM}$ \\
$\mathrm{K}_{\text {-gluconate }}$ & $80 \mathrm{mM}$ & $80 \mathrm{mM}$ & $80 \mathrm{mM}$ \\
$\mathrm{HEPES}$ & $10 \mathrm{mM}$ & $10 \mathrm{mM}$ & $10 \mathrm{mM}$ \\
EGTA & $0.2 \mathrm{mM}$ & $0.2 \mathrm{mM}$ & $0.2 \mathrm{mM}$ \\
$\mathrm{Na}_{2}-\mathrm{ATP}$ & $1 \mathrm{mM}$ & $1 \mathrm{mM}$ & $1 \mathrm{mM}$ \\
$\mathrm{Na}_{2}-\mathrm{GTP}$ & $0.1 \mathrm{mM}$ & $0.1 \mathrm{mM}$ & $0.1 \mathrm{mM}$ \\
cAMP $_{\text {CGMP }}$ & - & $1 \mathrm{mM}$ & - \\
fluo-4 K & - & $0.1 \mathrm{mM}$ & - \\
\hline
\end{tabular}

adjusted to $\mathrm{pH} 7.8$ and $190 \mathrm{mOsm} / \mathrm{liter}$

Table 3: Composition of internal solutions. The composition of all pipette solutions are listed here. All components besides fluo-4 potassium salt (Invitrogen) were purchased from Sigma. Abbreviations: ps: pipette solution, cAMP/cGMP ps: cAMP and cGMP containing pipette solution, fluo-4 ps: fluo-4 potassium salt containing pipette solution. 


\subsubsection{Odors}

\begin{tabular}{|c|c|c|c|}
\hline odor & $\begin{array}{l}\text { concentration of } \\
\text { stock solution }\end{array}$ & odor & $\begin{array}{l}\text { concentration of } \\
\text { stock solution }\end{array}$ \\
\hline \multicolumn{2}{|c|}{19 amino acid mix } & \multicolumn{2}{|l|}{ amine mix } \\
\hline L-glycine & $10 \mathrm{mM}$ & 2-phenylethylamine & $25 \mathrm{mM}$ \\
\hline L-alanine & $10 \mathrm{mM}$ & tyramine & $25 \mathrm{mM}$ \\
\hline L-serine & $10 \mathrm{mM}$ & butylamine & $25 \mathrm{mM}$ \\
\hline L-threonine & $10 \mathrm{mM}$ & cyclohexylamine & $25 \mathrm{mM}$ \\
\hline L-cysteine & $10 \mathrm{mM}$ & hexylamine & $25 \mathrm{mM}$ \\
\hline L-asparagine & $10 \mathrm{mM}$ & 3-methylbutylamine & $25 \mathrm{mM}$ \\
\hline L-glutamine & $10 \mathrm{mM}$ & $\mathrm{N}, \mathrm{N}$-dimethylethylamine & $25 \mathrm{mM}$ \\
\hline L-valine & $10 \mathrm{mM}$ & 2-methylbutylamine & $25 \mathrm{mM}$ \\
\hline L-leucine & $10 \mathrm{mM}$ & 1-formylpiperidine & $25 \mathrm{mM}$ \\
\hline L-isoleucine & $10 \mathrm{mM}$ & 2-methylpiperidine & $25 \mathrm{mM}$ \\
\hline L-methionine* & $10 \mathrm{mM}$ & N-ethylcyclohexylamine & $25 \mathrm{mM}$ \\
\hline L-proline & $10 \mathrm{mM}$ & 1-ethylpiperidine & $25 \mathrm{mM}$ \\
\hline L-arginine* & $10 \mathrm{mM}$ & piperidine & $25 \mathrm{mM}$ \\
\hline L-lysine* & $10 \mathrm{mM}$ & \multicolumn{2}{|l|}{ alcohol mix } \\
\hline L-histidine & $10 \mathrm{mM}$ & beta-phenylethylalcohol & $25 \mathrm{mM}$ \\
\hline L-glutamate & $10 \mathrm{mM}$ & citral & $25 \mathrm{mM}$ \\
\hline L-aspartate & $10 \mathrm{mM}$ & beta-Ionone & $25 \mathrm{mM}$ \\
\hline L-tryptophane & $10 \mathrm{mM}$ & gamma-phenylpropylalcohol & $25 \mathrm{mM}$ \\
\hline L-phenylalanine & $10 \mathrm{mM}$ & terpineol & $25 \mathrm{mM}$ \\
\hline
\end{tabular}

\begin{tabular}{l}
\hline bile acid mix \\
\hline taurocholic acid $10 \mathrm{mM}$ \\
\hline
\end{tabular}

Table 4: Odors. All odors were used as the indicated mixes or as the single amino acids arginine, lysine, and methionine (marked with *). All chemicals were purchased from Sigma and stock solutions were made in bath solution. 
All odors were used at a final concentration of $100 \mu \mathrm{M}$ dissolved in bath solution. Only the single amino acids arginine, lysine, and methionine were applied in various concentrations as indicated in the corresponding results section.

\subsubsection{Drugs}

\begin{tabular}{lllll}
\hline drug & company & solvent & $\begin{array}{l}\text { concentration of } \\
\text { stock solution }\end{array}$ & $\begin{array}{l}\text { concentration of } \\
\text { working solution }\end{array}$ \\
\hline FM1-43 & Invitrogen & Methanol & $2 \mathrm{mM}$ & $2 \mu \mathrm{M}$ \\
LY-83,583 & Sigma & Methanol & $50 \mathrm{mM}$ & $200 \mu \mathrm{M}$ \\
amiloride & Sigma & Distilled water & $100 \mathrm{mM}$ & $1 \mathrm{mM}$ \\
AM281 & Tocris & DMSO & $10 \mathrm{mM}$ & $10 \mu \mathrm{M}$ \\
AM251 & Tocris & DMSO & $10 \mathrm{mM}$ & $5 \mu \mathrm{M}$ \\
HU210 & Tocris & DMSO & $20 \mathrm{mM}$ & $10-20 \mu \mathrm{M}$ \\
RHC & Tocris & DMSO & $50 \mathrm{mM}$ & $25-50 \mu \mathrm{M}$ \\
orlistat & Tocris & DMSO & $25 \mathrm{mM}$ & $50 \mu \mathrm{M}$ \\
CE & Invitrogen & DMSO & $10 \mathrm{mM}$ & $5 \mu \mathrm{M}$ \\
\hline
\end{tabular}

Table 5: Drug solutions. The purchased drugs are listed with stock and working solutions. Abbreviations: CE: SE(5-(and-6)-carboxyeosin diacetate, succinimidyl ester). 


\section{Results}

\subsection{The styryl dye FM1-43 permeates and blocks CNG channels in olfactory receptor neurons of larval Xenopus laevis}

\subsubsection{FM1-43 stains a subset of ORNs}

In a first set of experiments, living Xenopus laevis tadpoles were put into water containing the styryl dye FM1-43 $(2 \mu \mathrm{M})$. Thereafter the animals were sacrificed and tissue slices were prepared from the OE. When the slices were viewed with a confocal laser scanning microscope, a large number of cells were stained in the entirety of their cytosol (Figure 9 A), whereas control slices showed no fluorescence (exposed to the same treatment but without FM1-43; Figure 9 B). For a better orientation the fluorescence images were overlayed with the corresponding transmission images scanned through wide-field optics. Figure $9 \mathrm{C}$ shows the magnified rectangular area of $B$ as a z-projection to illustrate the fine structure of the stained cells. Dendrites running to the surface of the OE, where cilia or microvilli issued from dendritic knobs, and axons running into the opposite direction to join the olfactory nerve unambiguously defined these cells as ORNs. Nuclei remained unstained. No staining at all was found in the vomeronasal organ (not shown).

\subsubsection{FM1-43-stained ORNs rarely respond to odors}

FM1-43 never stained the entire OE. It rather appeared to stain a certain subset of ORNs. To characterize the ORNs of this subset it was tried to test their sensitivity to amino acids, bile acids, amines, alcohols, and a mixture of all (100 $\mu \mathrm{M}$ for each substance). 156 out of 165 stained ORNs did not respond to any of the stimuli, which is in contrast to the high responsiveness of Xenopus tadpole ORNs as seen in previous studies (Manzini and Schild, 2004; Schild and Manzini, 2004). Only nine 

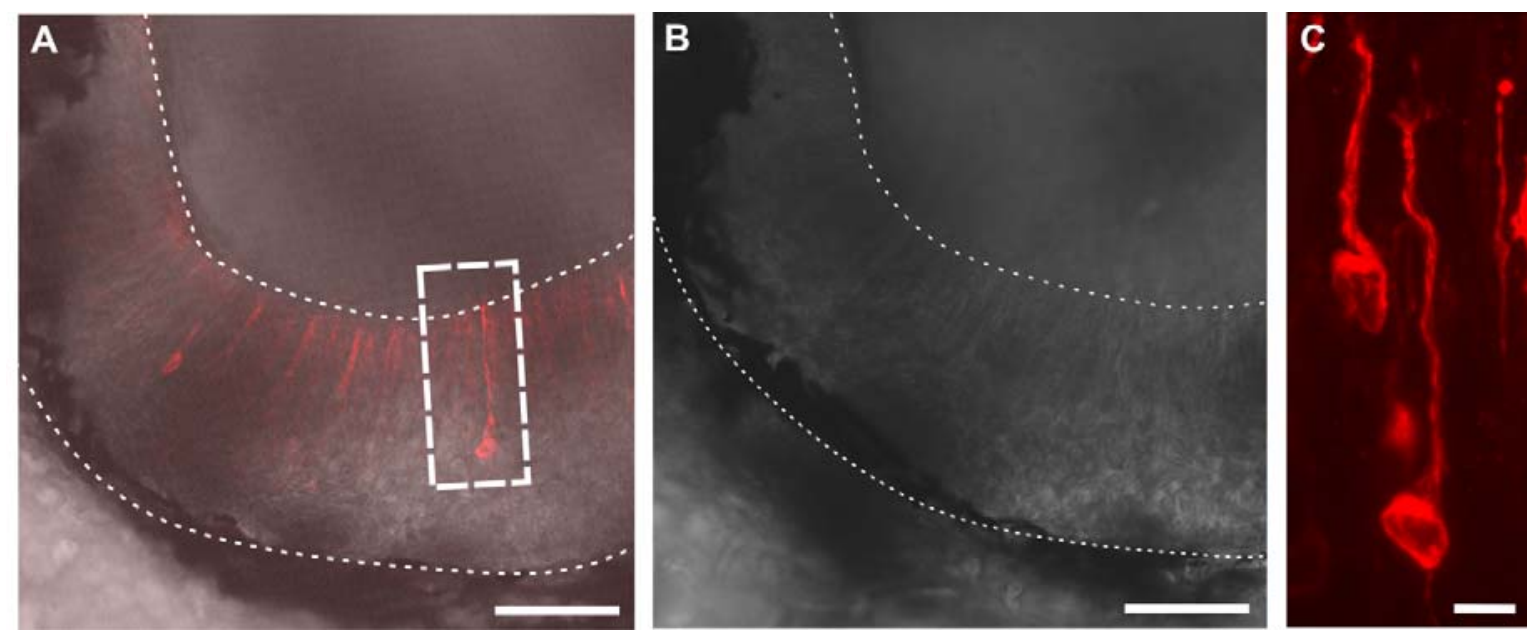

Figure 9: FM1-43 is selectively internalized by a subset of ORNs. (A, B) The image shows OEs of tadpoles with and without FM1-43 incubation, respectively. (C) The zprojection and magnification of $(A)$ illustrates the morphology of FM1-43-labeled ORNs by the cytosolic staining. Scale bars: (A, B) $50 \mu \mathrm{m},(C) 10 \mu \mathrm{m}$.

ORNs were responsive to the mixture, one of them to alcohols and four to amines. Figure 10 A shows an FM1-43-loaded cell (red) in a fluo-4 stained slice (green) and Figure $10 \mathrm{~B}-\mathrm{H}$ gives a typical example showing primarily two things. First, this ORN was sensitive to alcohols (Figure $10 \mathrm{D}, \mathrm{G}$ ) but not to amino acids (Figure $10 \mathrm{C}$ ), bile acids (Figure $10 \mathrm{E}$ ) and amines (Figure $10 \mathrm{~F}$ ) and second, the response amplitudes to both the stimulus mixture (Figure $10 \mathrm{~B}, \mathrm{H}$ ) and to alcohols (Figure $10 \mathrm{D}, \mathrm{G}$ ) rapidly declined over time and then vanished. The facts that FM1-43 stained only a subset of ORNs and that most of the stained ORNs did not respond at all, while those few which initially did respond rapidly lost their responsiveness, suggested that the responsiveness of the stained ORNs was severely compromised by FM1-43. 
A

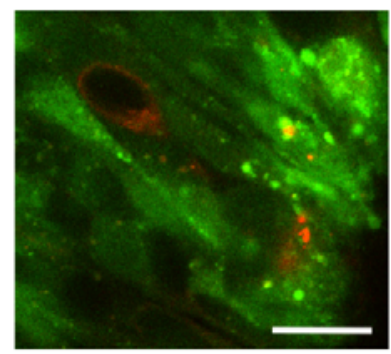

D

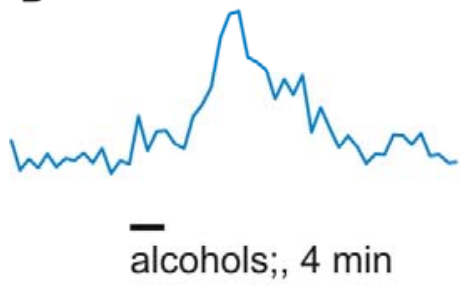

G

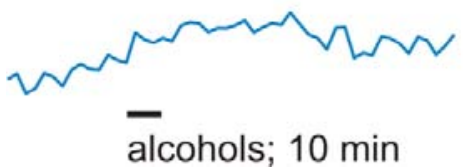

B

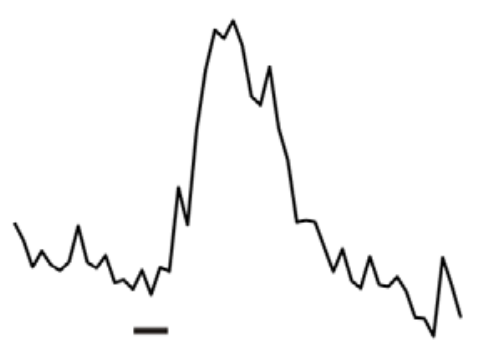

mix; 0 min

E

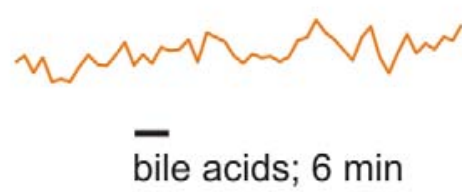

H

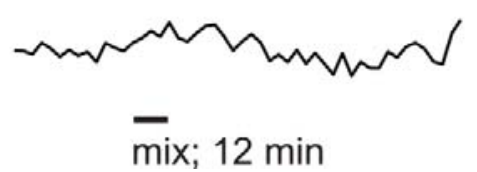

C

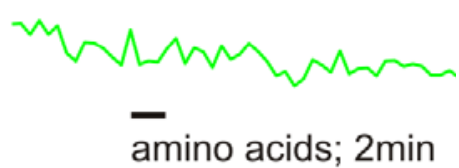

F

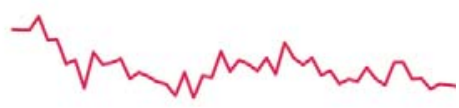

amines; 8 min

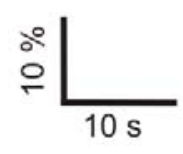

Figure 10: Odor-induced $\left[\mathrm{Ca}^{2+}\right]_{i}$ transients of an FM1-43-stained ORN. (A) The image shows a doublestained OE slice with fluo4-AM (green) and a FM1-43-loaded ORN (red; image acquired at rest). (B-H) The $\left[\mathrm{Ca}^{2+}\right]_{i}$ transients of the FM1-43-labeled ORN from (A) evoked by odorant mixtures $(B, H)$, amino acids $(C)$, alcohols $(D, G)$, bile acids $(E)$, and amines $(\mathrm{F} ; 100 \mu \mathrm{M}$ for each) are shown in chronological order. Scale bars: $10 \mathrm{~s}$ and $\Delta \mathrm{F} / \mathrm{F}$ $=10 \%$. The black lines indicate the application of the odorants. 

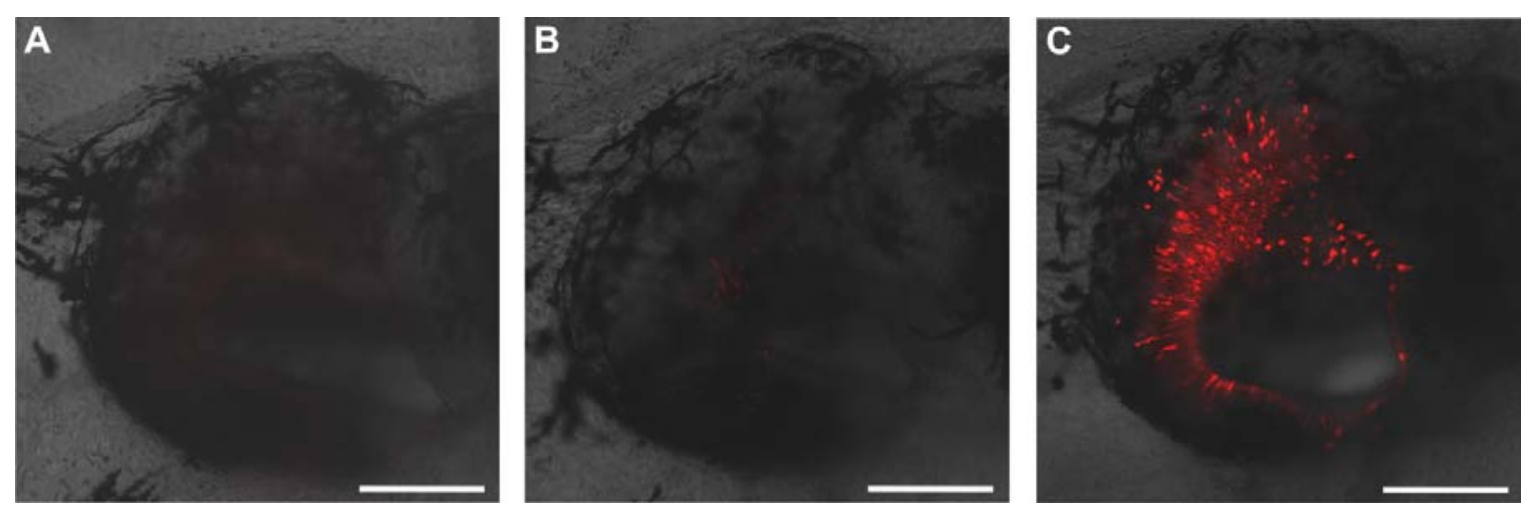

Figure 11: Block of FM1-43 labeling by cations. Incubation of the tadpoles in FM1-43 solution with (A) $2 \mathrm{mM} \mathrm{CaCl}_{2}$ or (B) $1 \mathrm{mM} \mathrm{MgCl}_{2}$ almost completely blocked FM1-43 uptake. (C) Under control conditions many ORNs were labeled when living tadpoles were incubated in $2 \mu \mathrm{M}$ FM1-43 solution. Scale bars: $200 \mu \mathrm{m}$.

\subsubsection{FM1-43 is selectively internalized by CNG channels}

As FM1-43 uptake took place in the OE in vivo, it certainly occurred through the plasma membrane of the compartments exposed to the principal cavity, i.e., through cilia, microvilli, and/or dendritic knobs. Furthermore, as FM1-43 fluorescence was cytosolic and as it built up rapidly, FM1-43 permeated into the cytosol presumably via ion channels rather than via transport proteins. It was therefore checked whether CNG channels were permeable for FM1-43 using the well-known permeability properties of divalent ions in CNG channels as well as the effect of two non-specific blockers of CNG channels.

When $\mathrm{CaCl}_{2}(2 \mathrm{mM} ; \mathrm{n}=5)$ or $\mathrm{MgCl}_{2}(1 \mathrm{mM} ; \mathrm{n}=5)$ was added to the water during in vivo incubation with FM1-43, the fluorescence intensity of ORNs was reduced to almost zero (Figure $11 \mathrm{~A}\left(\mathrm{CaCl}_{2}\right)$ and Figure $11 \mathrm{~B}\left(\mathrm{MgCl}_{2}\right)$, control: Figure $11 \mathrm{C})$. This would be consistent with an uptake of FM1-43 through CNG channels as 

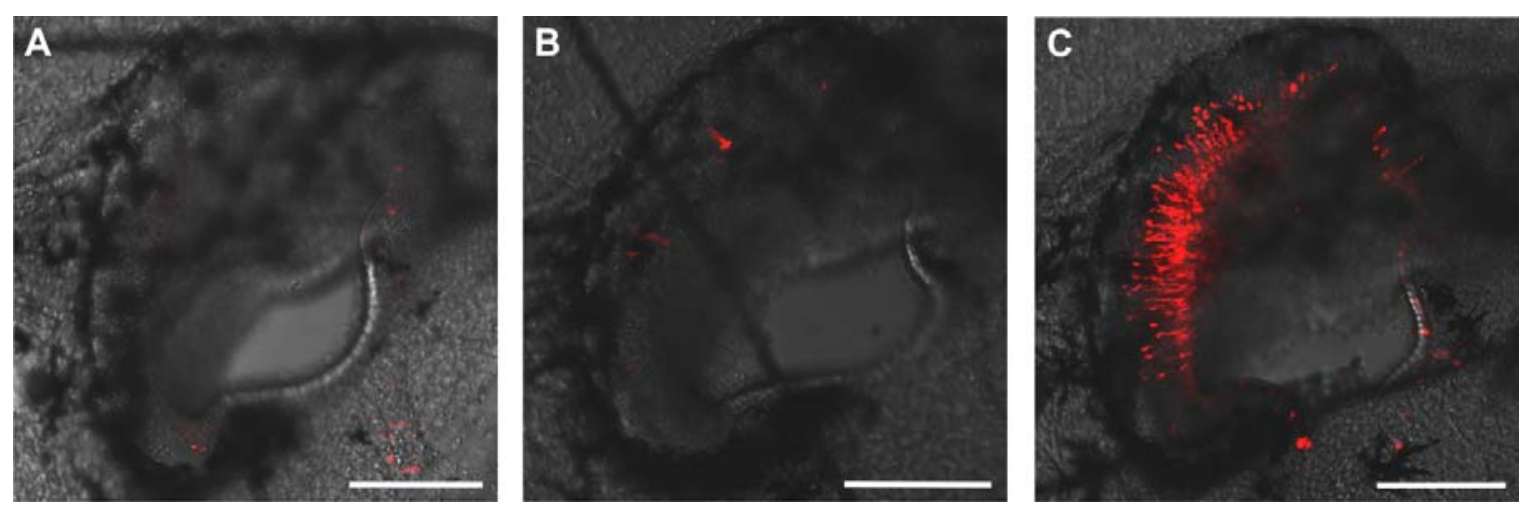

Figure 12: Block of FM1-43 labeling by unspecific CNG channel blockers. Incubation of the tadpoles in FM1-43 solution with the unspecific CNG channel blockers (A) LY$83,583(200 \mu \mathrm{M})$ or $(B)$ amiloride $(1 \mathrm{mM})$ blocked FM1-43 uptake compared to control conditions (C). Scale bars: $200 \mu \mathrm{m}$.

$\mathrm{Ca}^{2+}$ has been reported to exert a permeation block in these channels (Frings et al., 1995).

If FM1-43 permeates through CNG channels its permeation should be affected by LY-83,583 or amiloride. When LY-83,583 $(200 \mu \mathrm{M})$, which blocks CNG channels and the soluble guanylyl cyclase (Leinders-Zufall and Zufall, 1995), was added during dye incubation, the uptake of FM1-43 was completely blocked (Figure $12 \mathrm{~A}$, $\mathrm{n}=10$; control: Figure $12 \mathrm{C}$ ). The presence of amiloride (1 mM), which blocks CNG channels, $\mathrm{Na}^{+}$channels, T-type $\mathrm{Ca}^{2+}$ channels and several transporters (Benos, 1982; Zhuang et al., 1984; Tang et al., 1988; Frings et al., 1992), during incubation also reduced FM1-43 uptake dramatically (Figure $12 \mathrm{~B}, \mathrm{n}=8$ ). These results suggest that CNG channels have a sizable permeability for FM1-43. The ORNs stained by FM1-43 may thus correspond to the subset of ORNs endowed with the canonical cAMP-transduction cascade.

The direct test of this hypothesis would be to evoke responses to CAMP in FM1-43-stained cells. Of course, this is conflicting with the hypothesis itself because FM1-43 would suppress the responses. It was tried to circumvent this problem by exposing the animals to FM1-43 for a relatively short time in order to have a 
A

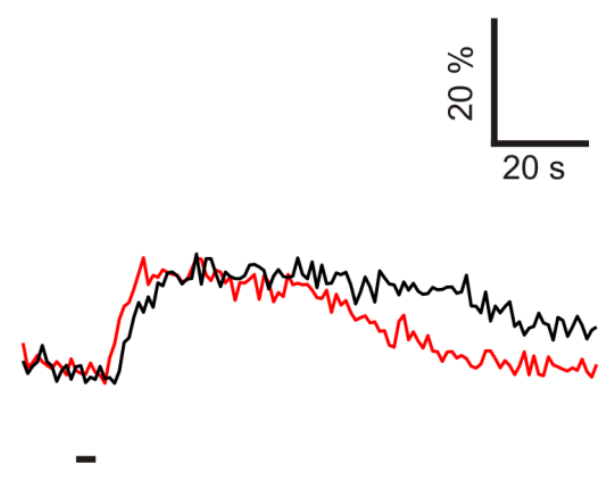

B

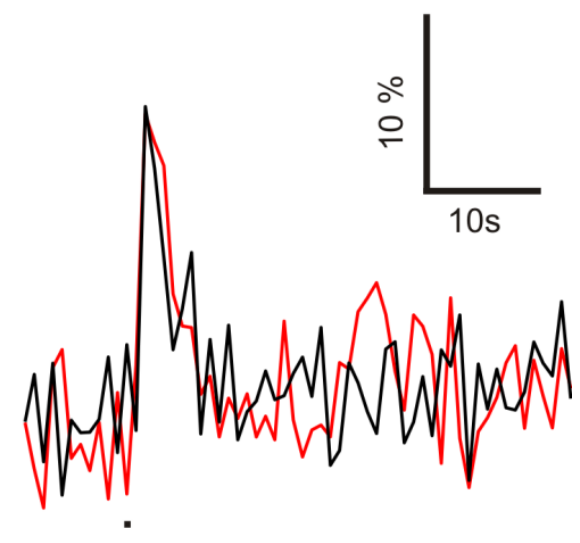

Figure 13: FM1-43-labeled ORNs are sensitive to forskolin and uncaging of CAMP. (A) Forskolin-evoked $\left[\mathrm{Ca}^{2+}\right]_{i}$ transients and (B) $\left[\mathrm{Ca}^{2+}\right]_{i}$ transients induced by uncaging of CAMP in individual FM1-43-stained ORNs are reproducible and have small amplitudes. Scale bars: (A) $20 \mathrm{~s}$ and $\Delta F / F=10 \%,(B) 10 \mathrm{~s}$ and $\Delta F / F=5 \%$. The black line indicates the application of the forskolin and the black dot the time point of uncaging.

correspondingly weak staining and at least some CNG channels functional. In fact, under these conditions, the ORN staining with FM1-43 was rather faint, and when the cells were stimulated with forskolin they showed weak but clear and reproducible responses (Figure $13 \mathrm{~A}$ ). Similar results were obtained in ten out of 13 cells (five slices). The three non-responding cells came all from the same slice. Uncaging of caged CAMP in FM1-43-loaded ORNs also resulted in a small, transient fluorescence increase of the $\mathrm{Ca}^{2+}$ indicator dye rhod-2 (Figure $13 \mathrm{~B}$; five out of five cells; three slices; performed together with E. Kludt).

Taken together, the block of FM1-43 uptake by divalent ions and by CNG channel blockers as well as the responses of faintly stained ORNs to forskolin and cAMP is consistent with the hypothesis that FM1-43 enters ORNs through CNG channels. 


\subsubsection{FM1-43 inhibits CNG currents}

Patch-clamped ORNs in untreated OE tissue slices were first identified as cAMPdependent or -independent by stimulation with forskolin in the on-cell mode of the patch clamp technique. Some ORNs responded to forskolin with a transient firing rate increase (Figure $14 \mathrm{~A}$ and $\mathrm{B}$, upper traces), while others, presumably due to the lack of CNG channels, showed no response to forskolin (Figure $14 \mathrm{C}$, upper trace). In a second step of the experiment the same cells were recorded in the whole-cell mode, with CAMP and CGMP added to the pipette solution. The effect of the second messengers that diffuse from the pipette into the cell was observed either with (Figure $14 \mathrm{~A}$ ) or without FM1-43 (Figure $14 \mathrm{~B}$ ) added to the bath solution. Without any FM1-43 in the bath an inward current set in immediately after breakthrough (Figure $14 \mathrm{~A}$, blue trace). To avoid, as much as possible, the activation of $\mathrm{Ca}^{2+}$ activated $\mathrm{Cl}^{-}$channels downstream the CNG channels, $\mathrm{Ca}^{2+}$ was omitted from the bath in these experiments, so that the recorded current was a current through CNG channels carried by $\mathrm{Na}^{+}$ions. Its average amplitude was $213.8+/-21.2$ pA (SEM; Figure $14 \mathrm{~A}$, blue trace; $\mathrm{n}=5)$. FM1-43 in the bath solution $(10 \mu \mathrm{M})$ reduced the inward current in cAMP-dependent cells upon breakthrough to $54.5+/-31.6 \mathrm{pA}$ (Figure $14 \mathrm{~B}$, red trace; $\mathrm{n}=6$ ). In non-cAMP-dependent ORNs, cAMP and cGMP never had any effect on the current (Figure $14 \mathrm{C}$, blue trace; $n=4$ ). An overview about the reduced CNG current amplitudes is given in Figure $14 \mathrm{D}$.

\subsubsection{Extracellular FM1-43 in the OE reduces forskolin-induced responses of glomeruli}

The previous experiment demonstrated that FM1-43 inhibits CNG channels, but the site of inhibition remains unclear. Therefore, the effect of extracellular FM1-43 on odor responses was investigated (experiment performed together with $E$. Kludt). Figure $15 \mathrm{~A}$ (black trace) shows a forskolin-application elicited $\left[\mathrm{Ca}^{2+}\right]_{\mathrm{i}}$ transient in a glomerulus in the medial cluster of a typical bulb whole mount preparation. When FM1-43 $(10 \mu M)$ was added to the bath solution, the amplitudes of the $\left[\mathrm{Ca}^{2+}\right]_{\mathrm{i}}$ transients were reduced (red trace). This effect was reversible by washing FM1-43 
A

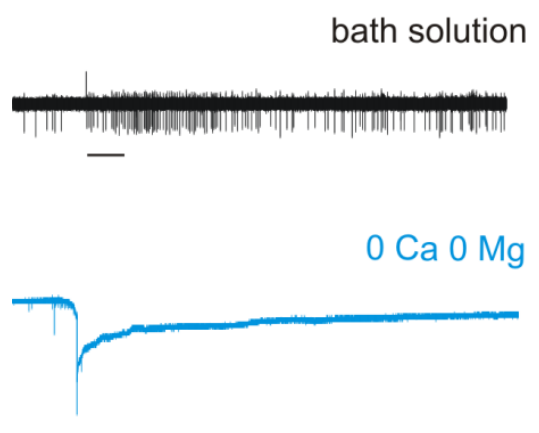

C

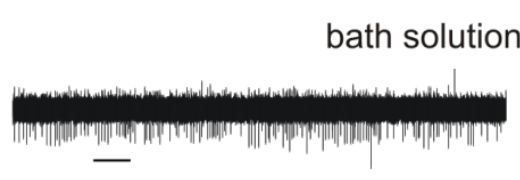

$0 \mathrm{Ca} 0 \mathrm{Mg}$
B

bath solution

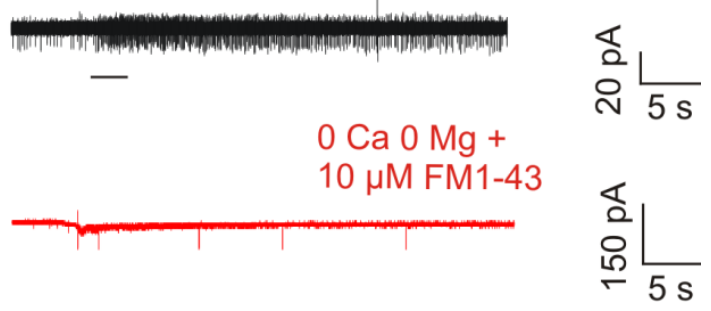

D

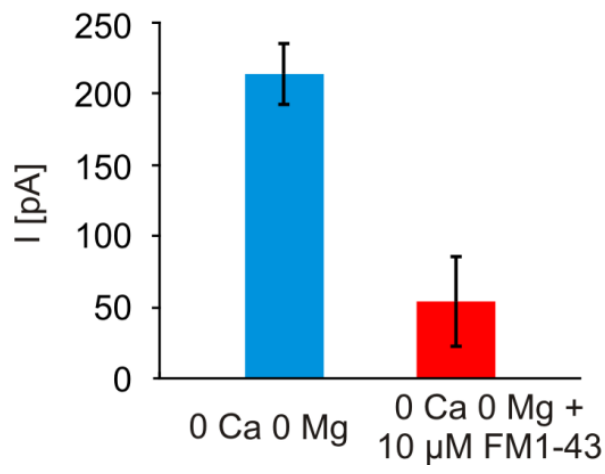

Figure 14: CNG currents are inhibited by FM1-43. (A, B, C) Cells were patch-clamped in the on-cell mode in bath solution. Forskolin induced an increased spike frequency in cAMP-dependent ( $A$ and $B$, black traces), but not in cAMP-independent ORNs ( $C$, black trace). Subsequently, the bath solution was substituted with $\mathrm{Ca}^{2+}$ - and $\mathrm{Mg}^{2+}$-free bath solution ( $0 \mathrm{Ca} 0 \mathrm{Mg}$ ) and the whole cell mode was established with CAMP and CGMP in the pipette solution. This induced an inward current in CAMP-dependent ORNs (A, blue trace), no current was detected in cAMP-independent neurons ( $C$, blue trace). ( $B$, red trace) When FM1-43 was present in the $\mathrm{Ca}^{2+}$ - and $\mathrm{Mg}^{2+}$-free bath solution, the amplitude of the inward current was reduced dramatically. (D) The current amplitudes of $(A ; n=5)$ and $(B ; n=6)$ are quantified in a bar graph. Scale bars: $(A-C) 5 \mathrm{~s}$ and $50 \mathrm{mV}$ or $50 \mathrm{pA}$. The black lines indicate the application of the forskolin.

out of the slice (grey trace; 11 glomeruli in 3 animals). Figure 15 B summarizes the obtained data. The mean amplitudes of the $\left[\mathrm{Ca}^{2+}\right]_{i}$ transients during FM1-43 wash-in and during wash-out are depicted normalized to those of the control experiment. The 
A

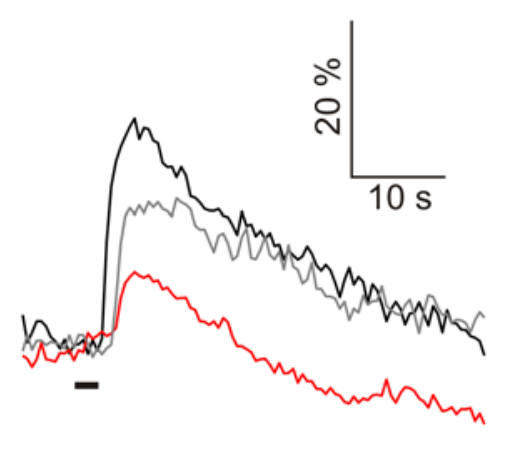

B

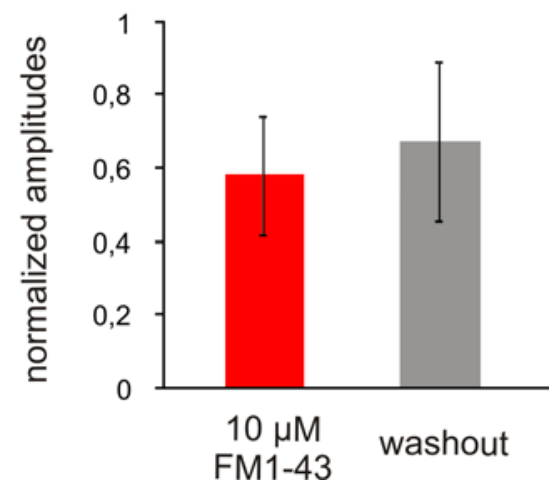

Figure 15: Extracellular FM1-43 inhibits glomerular responses. (A) Forskolin-evoked $\left[\mathrm{Ca}^{2+}\right]_{i}$ transients of glomeruli in the medial cluster of a typical olfactory bulb whole mount preparation (black trace) were reduced upon FM1-43 in the bath (10 $\mu \mathrm{M}$; red trace). Wash-out of the dye recovered the amplitude (grey trace; $n=11$ ). (B) The amplitudes are quantified in the bar graph. Scale bar: (A) $10 \mathrm{~s}$ and $\Delta \mathrm{F} / \mathrm{F}=20 \%$. The black line indicates the application of forskolin.

amplitude was reduced to $0.58 \pm 0.16$ upon $10 \mu \mathrm{M}$ FM1-43 in the bath compared to control conditions. Wash-out of the dye increased the amplitude to $0.67 \pm 0.22$ (Figure $15 \mathrm{~B}$ ). 


\subsection{Modulation of processing in olfactory receptor neurons by the endogenous cannabinoid system}

\subsubsection{Localization of the endocannabinoid system in OE}

Czesnik et al. (2007) proved that cannabinoids affect olfactory processing. This finding makes the presence of the endogenous cannabinoid system in the OE probable. In order to locate the endocannabinoid system in the OE, the mRNA content of the whole $\mathrm{OE}$ was analyzed for components of the endocannabinoid system with PCR. CDNA for the CB1 receptor, the 2-AG-catabolizing enzymes DAGL $\alpha$ and $\beta$ and MAGL, and the anandamide-catabolizing enzymes NAPE-PLD and FAAH were detected (Figure 16). Thus, 2-AG and anandamide can be produced and act in the OE.

\subsubsection{Suppression of 2-AG production reduces and delays odor-induced responses of ORNs}

Endocannabinoids play a physiological role in the OE. When the CB1 receptors of ORNs are blocked, responses to odorants are diminished and delayed (Czesnik et al., 2007). This effect could be explained by assuming a tonic synthesis and action of endocannabinoids in the OE. This assumption was checked by blocking 2-AG synthesis using the DAGL blockers RHC80267 or orlistat. The superfusion with these drugs had two effects. They prolonged the delay and reduced the amplitude of responses of individual ORNs to odorants. The black traces in Figure $17 \mathrm{~A}$ and $\mathrm{B}$ show typical $\left[\mathrm{Ca}^{2+}\right]_{\mathrm{i}}$ responses upon application of a mixture of amino acids $(100 \mu \mathrm{M})$ in two different ORNs taken from two different OE slice preparations. Superfusion of the slices with orlistat $(50 \mu \mathrm{M}$, for $10 \mathrm{~min})$ or RHC80267 $(50 \mu \mathrm{M}$, for $12 \mathrm{~min})$ diminished and delayed the $\left[\mathrm{Ca}^{2+}\right]_{i}$ responses (Figure $17 \mathrm{~A}, \mathrm{~B}$, respectively, red traces). This effect was highly reproducible (observed in 49 out of 49 cells, eight slices) with concentrations in the range of 25-50 $\mu \mathrm{M}$ (RHC80267) or $50 \mu \mathrm{M}$ (orlistat). 


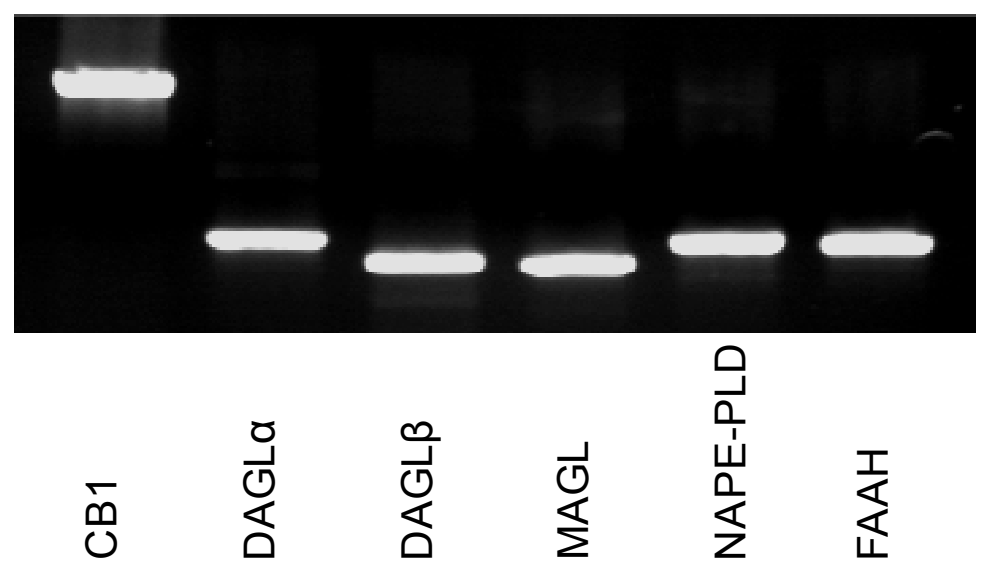

Figure 16: Endocannabinoid system in the OE of tadpoles. PCR products for mRNAs of the CB1 receptor (lane 1), the two DAGL isoforms $\alpha$ and $\beta$ (lane 2 and 3), MAGL (lane 4), NAPE-PLD (lane 5), and FAAH (lane 6) were electrophoretically separated in an ethidium bromide containing agarose gel and visualized with UV-light.

The recovery during drug wash-out was accelerated by the CB1 receptor agonist HU210. A wash-in of HU210 $(10 \mu \mathrm{M})$ for 2 min led to an almost complete recovery of the responses (Figure $17 \mathrm{~A}, \mathrm{~B}$, green traces). The described effects are very similar to those induced by blockage of CB1 receptors as published previously (Czesnik et al., 2007, Figure 17 C).

\subsubsection{Differential expression of the DAGL isoforms within the OE}

While the above data demonstrate that the suppression of odorant responses was brought about by the endocannabinoid 2-AG, produced by a DAGL, the production site of 2-AG, i.e. the site of DAGL activity remained unclear so far. Therefore the expression of the DAGL in the OE, specifically the expression of the $\alpha$ and $\beta$ isoforms was localized. Olfactory receptor neurons and sustentacular cells, which could easily be distinguished on the basis of their characteristic morphology, were first patch- 
A

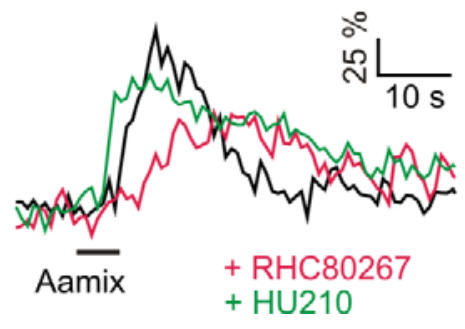

B

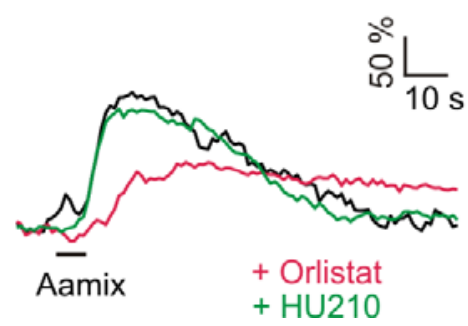

C

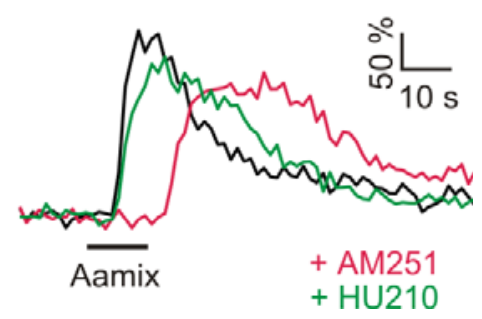

Figure 17: RHC80267 and orlistat suppress odor-evoked $\left[\mathrm{Ca}^{2+}\right]_{i}$ transients. $(\mathrm{A}, \mathrm{B})$ Aamix-evoked $\left[\mathrm{Ca}^{2+}\right]_{i}$ transients in somata of individual ORNs (black traces) were reduced and delayed after wash-in of the DAGL inhibitors orlistat $(50 \mu \mathrm{M})$ and RHC80267 $(50 \mu \mathrm{M})$ to the bath solution (red traces), respectively. 2 min after adding HU210 (10 $\mu \mathrm{M})$ to the bath, the $\left[\mathrm{Ca}^{2+}\right]_{\mathrm{i}}$ transients recovered almost completely (green traces). (C) Addition of the CB1 receptor antagonist AM281 $(5 \mu \mathrm{M})$ to the bath solution elicited almost identical effects as the DAGL blockage. Scale bars: $10 \mathrm{~s}$ and $\Delta F / F=25 \%(A)$ or $50 \%(B, C)$. The black lines indicate the application of the odorants.

clamped and physiologically identified. Then the cytoplasm of the patch-clamped cell was harvested into the patch pipette for further PCR analysis. The mRNA of olfactory marker protein 1 (OMP1) and of cytokeratin type II (CYTII) were used as markers to confirm the identity of ORNs and sustentacular cells, respectively (Rössler et al., 1998; Hassenklöver et al., 2008). Five out of ten ORNs (OMP1-positive) expressed $D A G L \beta$, and none of them expressed DAGL $\alpha$. On the other hand, five out of eight sustentacular cells (CYTII-positive) expressed DAGL $\alpha$, and none of them DAGL $\beta$. In summary, 2-AG is synthesized in both ORNs and sustentacular cells, though by two different isoforms of the DAGL (see examples in Figure 18). The $\beta$-isoform is active in ORNs and the $\alpha$-isoform in sustentacular cells. 


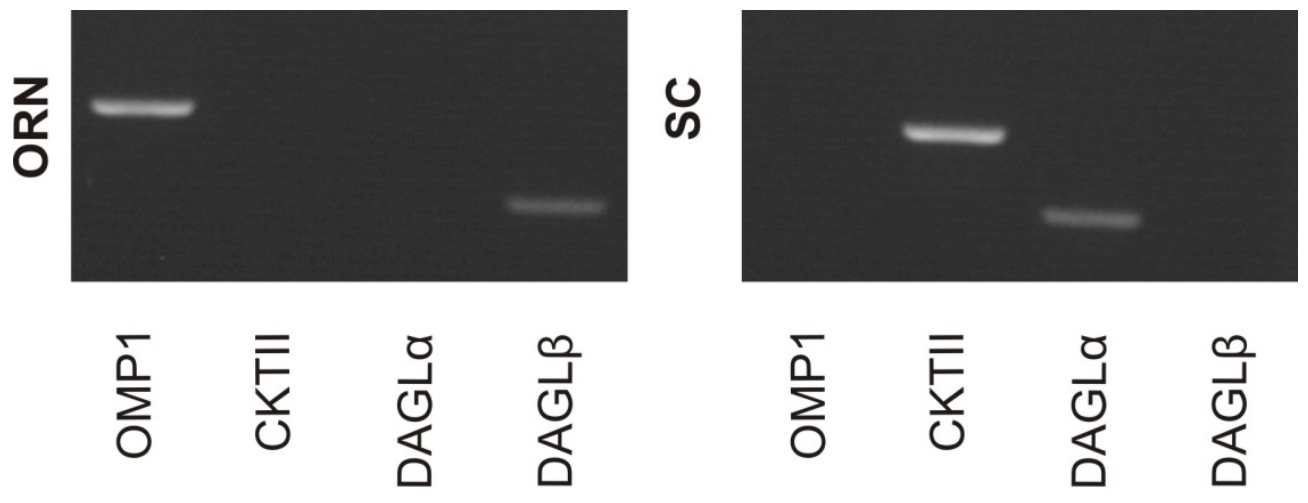

Figure 18: Differential DAGL $\beta$ and $\alpha$ expression in ORNs and sustentacular cells. Single-cell RT-PCR revealed mRNA of DAGL $\beta$ solely in ORNs (OMP1-positive cells) and mRNA of DAGLa in sustentacular cells (CYTII-positive cells).

\subsubsection{DAGLa expression is enhanced after food-deprivation}

In order to find a functional link between the nutritional or hunger state of an animal on the one hand and 2-AG synthesis on the other, it was investigated whether hunger affected the expression of DAGL. To this end mRNA of both DAGL isoforms were obtained and analyzed from five groups of animals using real-time PCR. The first and second group of animals were food-deprived either for $6 \mathrm{~h}$ (group $\mathrm{A}_{6 \mathrm{~h}}$ ) or for $12 \mathrm{~h}$ (group $\mathrm{A}_{12 \mathrm{~h}}$ ) before analyzing their mRNA levels. The third and forth group were fed to satiety for $2 \mathrm{~h}$ after having been food-deprived for $6 \mathrm{~h}$ (group $\mathrm{B}_{6 \mathrm{~h}}$ ) or $12 \mathrm{~h}$ (group $B_{12 h}$ ). A control group of animals (group $C$ ) was fed to satiety for $2 \mathrm{~h}$ before measurements. The mRNA expression levels for the A- and B-groups were normalized to those of the control group (Figure 19, grey line).

Comparing the expression levels of DAGLa (blue; sustentacular cells) and DAGL $\beta$ (red; ORNs), hunger clearly had no effect on 2-AG production in ORNs (Figure 19, red points), since the normalized changes of the DAGL $\beta$ (ORNs) by hunger (groups $A_{6 h}$ and $A_{12 h}$ ) or refeeding after hunger (groups $B_{6 h}$ and $B_{12 h}$ ) were 


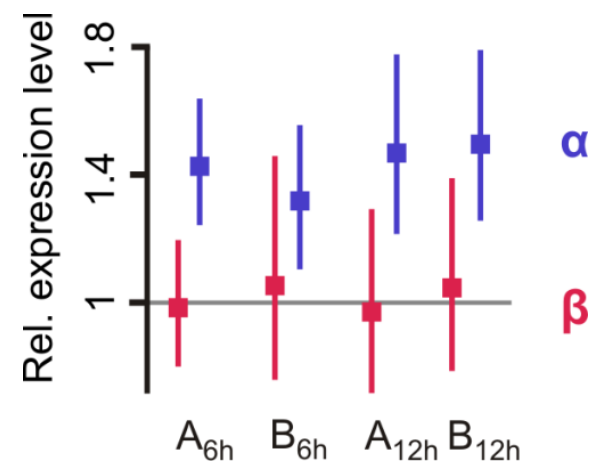

Figure 19: DAGL mRNA expression is regulated upon food-deprivation. Relative expression levels (i.e. normalized to the control group) of DAGL $\alpha$ in sustentacular cells (blue points) and $\beta$ in ORNs (red points) in the OE exposed to four nutritious states. DAGL $\alpha$ expression levels were affected by the various nutritious conditions (group $A_{6 h}$, food-deprived for $6 h, n=7,1.45$ fold; group $B_{6 h}$, food-deprived for $6 h$ and refed for $2 h$, $\mathrm{n}=7,1.32$ fold; group $A_{12 \mathrm{~h}}$, food-deprived for $12 \mathrm{~h}, \mathrm{n}=7,1.50$ fold; group $B_{12 \mathrm{~h}}$, fooddeprived for $12 \mathrm{~h}$ and refed for $2 \mathrm{~h}, \mathrm{n}=7,1.52$ fold). DAGL $\beta$ expression levels were not affected by the various nutritious conditions ( 0.99 fold, 1.07 fold, 0.97 fold, 1.05 fold $(n=7)$, respectively).

$0.99,1.07,0.97$, and 1.05 , respectively $(n=7)$. In contrast, in sustentacular cells, DAGL $\alpha$ expression was significantly enhanced after food deprivation for both $6 \mathrm{~h}$ (group $A_{6 h}$ ) and $12 \mathrm{~h}$ (group $A_{12 h}$ ). On average the mRNA expression levels were 1.45 times $\left(n=7 ; A_{6 h}\right)$ or 1.50 times $\left(n=7\right.$; group $\left.A_{12 h}\right)$ higher than in the control group. Refeeding for $2 \mathrm{~h}$ after $6 \mathrm{~h}$ food deprivation diminished the increase slightly (mean: 1.32 fold; $n=7$; group $B_{6 h}$ ), while the enhanced expression levels after $12 \mathrm{~h}$ food deprivation showed no recovery (mean: 1.52 fold; $n=7$, group $B_{12 h}$ ).

\subsubsection{The endocannabinoid level tunes odor thresholds of individual ORNs}

The above data suggested that 2-AG modulates the sensitivity of ORNs. As to possible sensitivity measures, the obvious candidates were the concentration at 
A

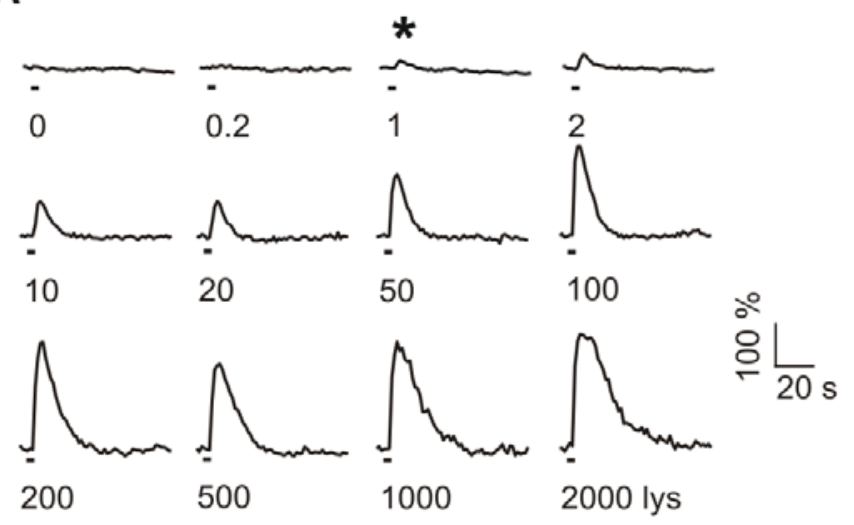

C

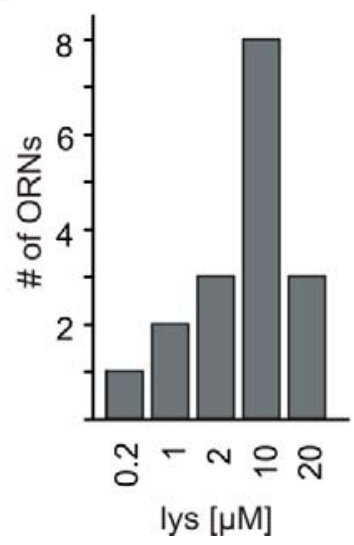

B
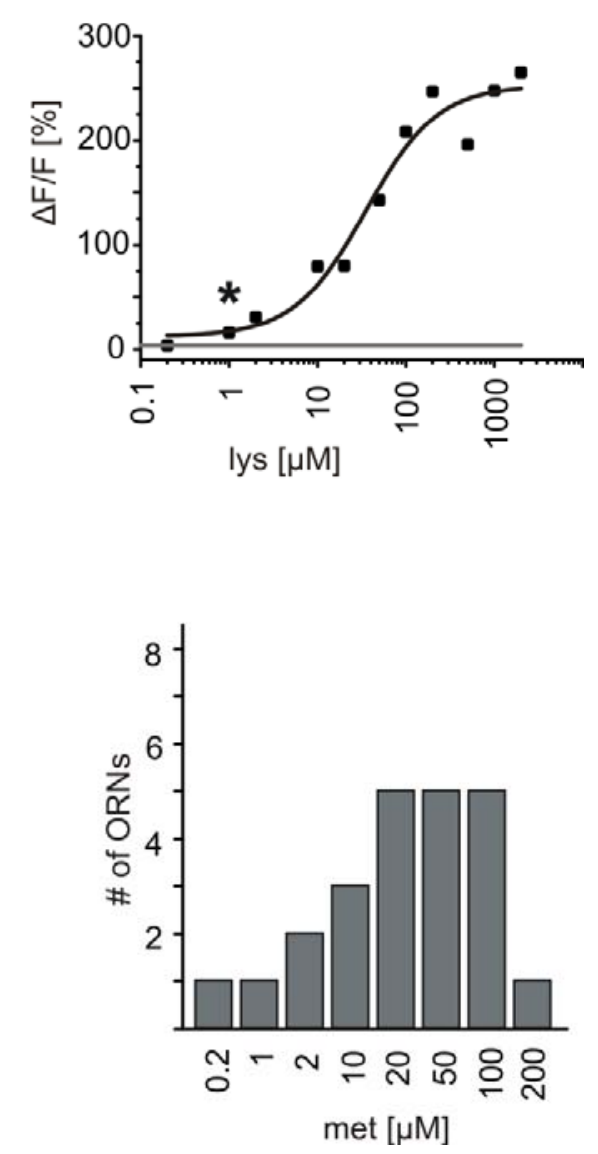

Figure 20: Dose-response relationships of $\left[\mathrm{Ca}^{2+}\right]_{\mathrm{i}}$ transients induced by single amino acids. (A) $\left[\mathrm{Ca}^{2+}\right]_{i}$ transients of a single ORNs elicited by increasing concentrations $(0,0.2,1,2,10,20,50,100,200,500,1000$ and 2000 , in $\mu M)$ of lysine (lys) are shown. The detection threshold concentration $\left(^{*}\right)$ in this example is $1 \mu \mathrm{M}$. (B) the amplitudes obtained by the demonstrated dose-response-measurements were fitted by a Boltzmann equation. (C) Histograms of all investigated ORNs were classified for the three amino acids lysine (lys), arginine (arg) and methionine (met) according to their individual detection thresholds. The black lines indicate the application of the odorants.

which the dose-response curve is half-maximum, $\mathrm{K}_{1 / 2}$, or the threshold concentration below which an ORN shows no response to the stimulus, $\mathrm{C}_{\text {th }}$. Dose-response curves of ORNs for a number of stimuli (arginine, methionine and lysine) were measured (done by B. Gutermann) and fitted to a Boltzmann function. Figure 20 A, B shows 
ORN responses to lysine together with the corresponding dose-response curve as an example. The midpoint slopes of the 65 dose-response curves measured varied considerably (by a factor $>10$ ) so that curves having the same $\mathrm{K}_{1 / 2}$ had quite different $\mathrm{C}_{\text {th }}$ values (not shown). Therefore the threshold concentration, $\mathrm{c}_{\mathrm{th}}$, was preferred as a convenient measure of sensitivity, whereby $\mathrm{C}_{\mathrm{th}}$ is defined as the concentration below which, under control conditions, no responses could be measured. Specifically, the first data point of the monotonic increase of the dose-response-curve was taken as the detection threshold $\mathrm{c}_{\text {th }}$. Note that this definition refers to control conditions (i.e., no food shortage and no drugs applied).

The detection thresholds varied from ORN to ORN over a wide range. Figure $20 \mathrm{C}$ gives the threshold distributions for the three odorants used.

To investigate the effect of 2-AG on the odorant detection threshold of a specific ORN, a control experiment as shown in Figure $21 \mathrm{~A}$ was carried out first. The orange trace gives an arginine-induced $\left[\mathrm{Ca}^{2+}\right]_{i}$ transient at the detection threshold $\mathrm{c}_{\text {th }}$ (in this case, $20 \mu \mathrm{M}$ ). Expectedly, a higher odorant concentration induced a larger response amplitude and a shorter response latency (black trace, $50 \mu \mathrm{M}$ ), while concentrations below $\mathrm{C}_{\text {th }}$ failed to elicit a response in this ORN (blue trace, $10 \mu \mathrm{M}$ ). Importantly, this response behavior was well reproducible (Figure $21 \mathrm{~B}$, orange and brown traces, blue and light blue traces). Now the slice was superfused with the DAGL blocker RHC80267, which consistently led to response failures at $\mathrm{C}_{\text {th }}$ (Figure $21 \mathrm{C}$, red trace, $\mathrm{RHC} 80267,50 \mu \mathrm{M}$ ), meaning that the threshold $\hat{c}_{\mathrm{th}}$, under the experimental condition of less 2-AG being produced was shifted to a higher value, i.e., $\hat{C}_{\text {th }}>C_{t h}$. Mimicking the presence of 2-AG by wash-in of the CB1 receptor agonist $\mathrm{HU} 210\left(10 \mu \mathrm{M}\right.$ ) was able to rescue the odorant responses at $\mathrm{C}_{\text {th }}$ (Figure $21 \mathrm{C}$, green trace). Moreover, HU210 was not only able to rescue the response; frequently it also lowered the threshold so that responses could be recorded at subthreshold odorant concentrations $\left(c<c_{t h}\right)$. This is shown in Figure $21 \mathrm{D}$, where an odor response failure at $10 \mu \mathrm{M}\left(\mathrm{c}<\mathrm{c}_{\mathrm{th}}\right.$, blue trace) is transformed into a clear response at the same concentration after HU210 was added to the bath (Figure $21 \mathrm{D}$, green trace). There is thus no doubt that the sensitivities of ORNs are modulated by endocannabinoids.

While Figure $21 \mathrm{C}$ gave a typical example, Figure $22 \mathrm{~A}$ summarizes the data for all ORNs recorded under this condition. The cells are grouped with respect to their threshold concentration $c_{\text {th }}$ (abscissa). The left (orange) column of each column 
A

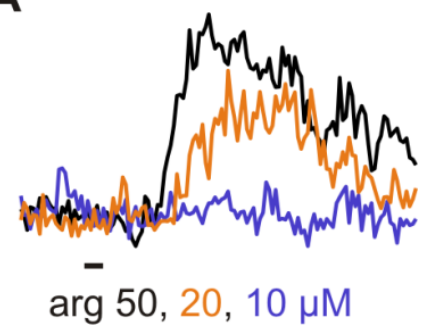

C

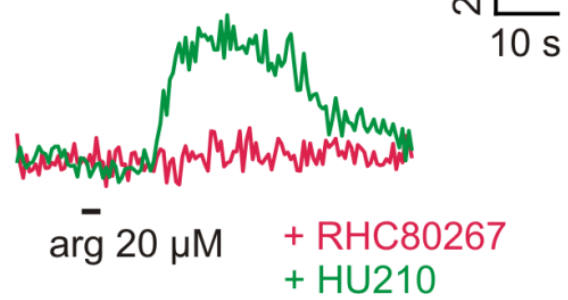

B

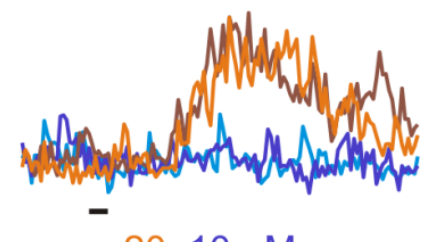

$\arg 20,10 \mu \mathrm{M}$

D

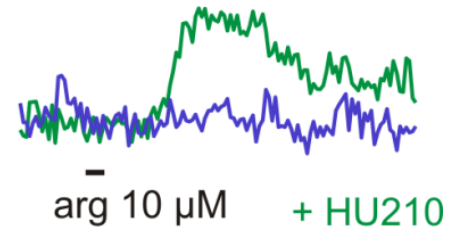

Figure 21: ORNs have individual and tunable odorant detection thresholds according to the 2-AG level in the OE. (A) ORN $\left[\mathrm{Ca}^{2+}\right]_{i}$ responses to various concentrations of $\arg (10,20,50 \mu \mathrm{M})$. (B) The responses to the detection threshold $\mathrm{c}_{\text {th }}(20$ $\mu \mathrm{M}$, orange and brown traces) and concentrations below $\mathrm{c}_{\text {th }}(10 \mu \mathrm{M}$, blue and light blue traces) were highly reproducible. (C) After addition of RHC80267 $(50 \mu \mathrm{M})$ to the bath solution the $\left[\mathrm{Ca}^{2+}\right]_{i}$ transients induced at $\mathrm{c}_{\text {th }}$ were abolished (red trace). Wash-out of RHC80267 with HU210 in the bath solution ( $2 \mathrm{~min}, 10 \mu \mathrm{M}$, green trace) accelerated recovery. (D) Lacking odorant response under control conditions (arg, blue trace) and reappearing of odorant response after addition of HU210 (2 min, green trace) to the bath. The black lines indicate the application of the odorants.

triplet of the histogram gives the number of ORNs found to have the threshold concentration indicated on the abscissa. The middle column (red) gives the number of ORNs that show a response suppression (threshold increase) upon DAGL blockage, and the right column of each column triplet (green) shows how many ORNs regained an odor response after adding HU210 to the bath. An increase of threshold concentration upon application of RHC80267 or orlistat was observed in 54 out of 54 ORNs (52 slices; 18 cells for arginine, 21 cells for lysine and 15 cells for 
A

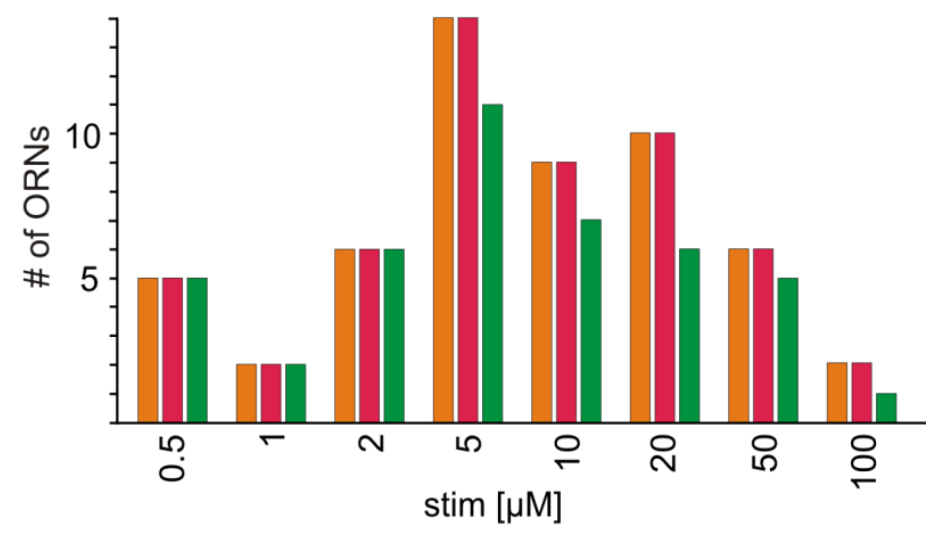

B

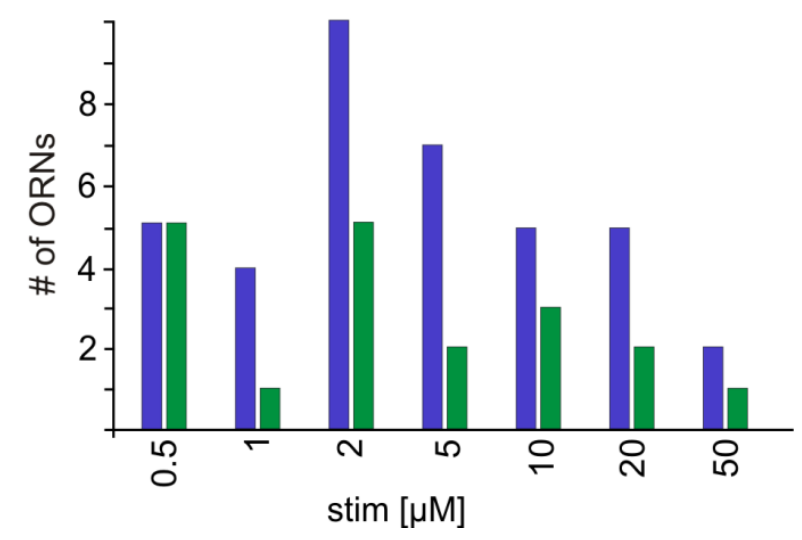

Figure 22: Summary of detection threshold modulation. (A) Histogram of a group of ORNs responsive to arginine, lysine or methionine classified according to their individual detection thresholds $c_{\text {th }}$ under control conditions (orange bars). In all of these ORNs $\mathrm{RHC} 80267$ or orlistat led to a reduction of the response (red bars) whereby a recovery (drug wash-in of HU210 $10 \mu \mathrm{M}$, green bars) could be observed in 42 out of 53 ORNs. (B) Histogram of groups of arginine-, lysine- or methionine-responsive ORNs (blue bars) plotted over the highest concentration where no response could be recorded. In 19 out of 38 ORNs HU210 $(10 \mu \mathrm{M})$ permitted responses at the respective concentrations (green bars).

methionine; red bars), and the agonist HU210 led to a recovery in 42 out of these 54 ORNs (green bars). 
A

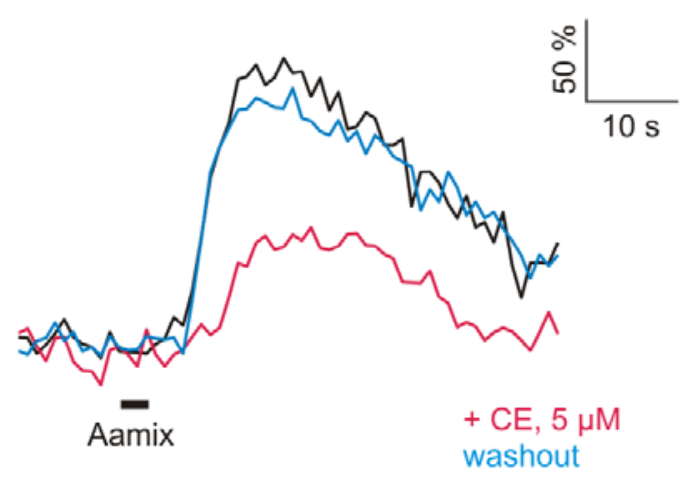

C

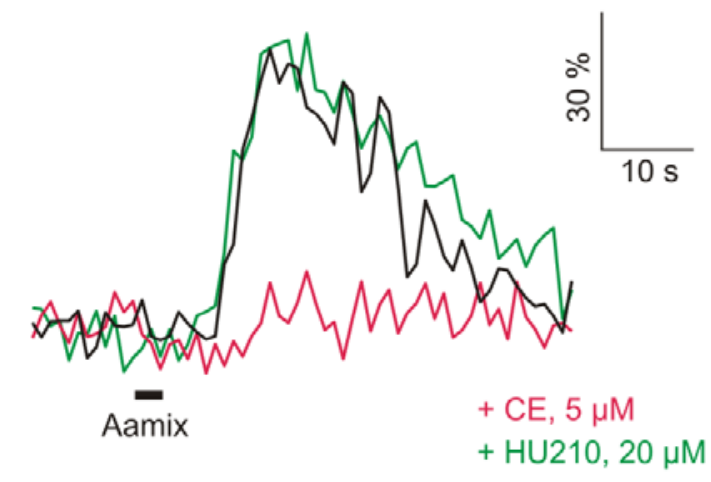

B

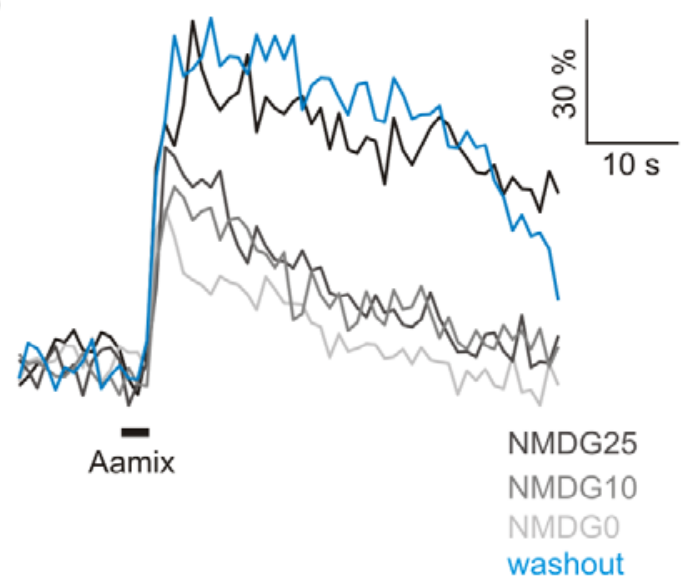

D

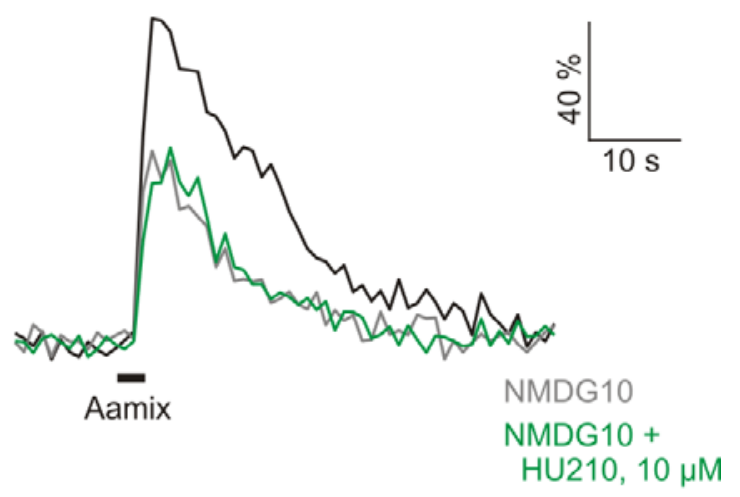

E

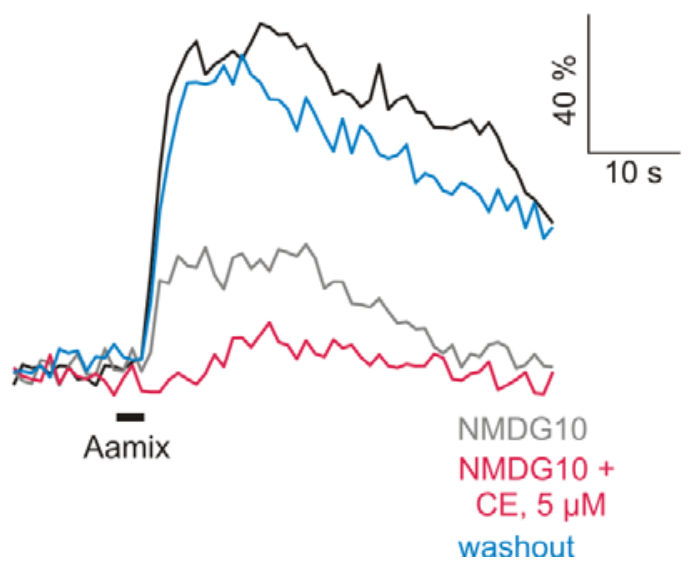

Figure 23: PMCA but not NCX mediates CB1 receptor-induced effects. (A) AamiXevoked $\left[\mathrm{Ca}^{2+}\right]_{i}$ transients of individual ORNs (black traces) were reduced and delayed after wash-in of the PMCA inhibitor CE ( $5 \mu \mathrm{M}$; red trace). After drug wash-out with bath solution, the $\left[\mathrm{Ca}^{2+}\right]_{i}$ transients recovered (blue traces). (B) Aamix-evoked $\left[\mathrm{Ca}^{2+}\right]_{i}$ transients of individual ORNs (black traces) were only reduced after substation of $\mathrm{Na}^{+}$with NMDG (NMDG25: dark grey; NMDG10: middle grey; NMDG0: light grey). After drug wash-out with bath solution, the $\left[\mathrm{Ca}^{2+}\right]_{i}$ transients recovered (blue traces). (C) CE-modulated $\left[\mathrm{Ca}^{2+}\right]_{\mathrm{i}}$ 
Figure 22 B summarizes the experiments where stimulation was at subthreshold concentrations, i.e., at $\mathrm{c}<\mathrm{c}_{\mathrm{th}}$, where no responses could be elicited, and repeated the stimulation with the CB1 agonist HU210 added to the bath. With HU210 in the bath, responses were observed in 19 (green) out of 38 (blue) cells (38 slices). There was no correlation between the occurrence of this effect and the corresponding threshold concentration.

\subsubsection{Preliminary: PMCA is effector molecule of the CB1 receptor in ORNs}

Although the cellular effect of CB1 receptor blockage and activation was demonstrated, the underlying signaling systems are unknown so far. CB1 receptor signaling mostly modulates intracellular $\mathrm{Ca}^{2+}$ levels. $\mathrm{Ca}^{2+}$ is extruded from ORNs by the plasma membrane $\mathrm{Ca}^{2+}$ ATPase (PMCA; Lischka and Schild, 1993; Castillo et al., 2007) and the $\mathrm{Na}^{+}-\mathrm{Ca}^{2+}$-exchanger (NCX; Reisert and Matthews, 1998; Lucero et al., 2000).

transients (red trace; control: black trace) was rescued after drug wash-in of HU210 (20 $\mu \mathrm{M}$ ) in the bath solution (green traces). (D) NMDG10-modulated $\left[\mathrm{Ca}^{2+}\right]_{i}$ transients (grey trace; control: black trace) did not change upon HU210 (10 $\mu \mathrm{M})$ in the bath solution (green traces). (E) The control response to Aamix application (black trace) was reduced in amplitude upon NMDG10 (grey trace) and further reduced and delayed by wash-in of CE ( $5 \mu \mathrm{M}$; red trace). Wash-out with bath solution recovered the transient (blue trace). Scale bars: $10 \mathrm{~s}$ and $\Delta \mathrm{F} / \mathrm{F}=50 \%(\mathrm{~A}), 30 \%(\mathrm{~B}, \mathrm{C})$ or $40 \%(\mathrm{D}, \mathrm{E})$. The black lines indicate the application of the odorants. 
First, a possible involvement of PMCA in CB1 signaling was investigated. The PMCA blocker carboxyeosin (CE) was used during odorant stimulation of ORNs with amino acids. The black trace in Figure $23 \mathrm{~A}$ shows a $\left[\mathrm{Ca}^{2+}\right]_{i}$ transient upon stimulation with amino acids under control conditions. Wash-in of CE $(5 \mu \mathrm{M} ; 10 \mathrm{~min}$; Figure $23 \mathrm{~A}$, red trace) delayed the response and reduced its amplitude. This effect is similar to that observed for blockage of 2-AG synthesis (Figure 17). A subsequent wash-out of the drug recovered the response (Figure $23 \mathrm{~A}$, blue trace; observed in 28 out of 28 cells in three slices).

In the next step, the involvement of NCX in CB1 signaling was examined. To achieve a stop or even a reverse mode of the NCX and thus, retain $\mathrm{Ca}^{2+}$ ions in the cell, extracellular $\mathrm{Na}^{+}$was substituted for NMDG (NMDG25: $25 \mathrm{mM} \mathrm{NaCl}$, NMDG10: $10 \mathrm{mM} \mathrm{NaCl}, \mathrm{NMDG0}$ : $0 \mathrm{mM} \mathrm{NaCl}$; Schild et al., 1994). These conditions reduced the amplitude of $\left[\mathrm{Ca}^{2+}\right]_{\mathrm{i}}$ responses (Figure $23 \mathrm{~B}$, grey traces) compared to the control (Figure $23 \mathrm{~B}$, black trace). Restorage of extracellular $\mathrm{Na}^{+}$to $98 \mathrm{mM}$ recovered the response (Figure $23 \mathrm{~B}$, blue trace). A delay of the response could not be observed by NCX interference (observed in 28 out of 28 cells in four slices).

In the following experiments it was investigated whether these described effects occur downstream of the CB1 receptor or whether they are mediated CB1 receptor-independent. Thus, the experiment was slightly modified and the altered $\left[\mathrm{Ca}^{2+}\right]_{\mathrm{i}}$ responses upon PMCA or NCX blockage were tried to be rescued by wash-in of the CB1 receptor agonist HU210. The black traces in Figure $23 \mathrm{C}$ and D are $\left[\mathrm{Ca}^{2+}\right]_{i}$ responses to amino acids under control conditions. Wash-in of CE $(5 \mu \mathrm{M}$; Figure $23 \mathrm{C}$, red trace) reduced and delayed the response and substitution of extracellular $\mathrm{Na}^{+}$by NMGD (in this case NMDG 10; Figure $23 \mathrm{D}$, grey trace) only reduced the response. Subsequent wash-in of HU210 $(20 \mu \mathrm{M})$ rescued the response upon CE (Figure $23 \mathrm{C}$, green trace; observed in 21 out of 26 cells in four slices), but had no effect on the responses altered by NMDG10 (HU210, $10 \mu \mathrm{M}$; Figure $23 \mathrm{D}$, green trace; observed in 52 out of 52 cells in four slices). This suggests that PMCA is located downstream in the CB1 receptor signaling cascade in ORNs, but not NCX.

To further verify this finding, it was tested, whether CE still triggers the described effect when the NCX is out of action. The control response to amino acid application in Figure $23 \mathrm{E}$ (Figure $23 \mathrm{E}$, black trace) was reduced in amplitude upon NMDG10 (Figure $23 \mathrm{E}$, grey trace). Wash-in of CE (5 $\mu \mathrm{M}$; Figure $23 \mathrm{E}$, green trace) 


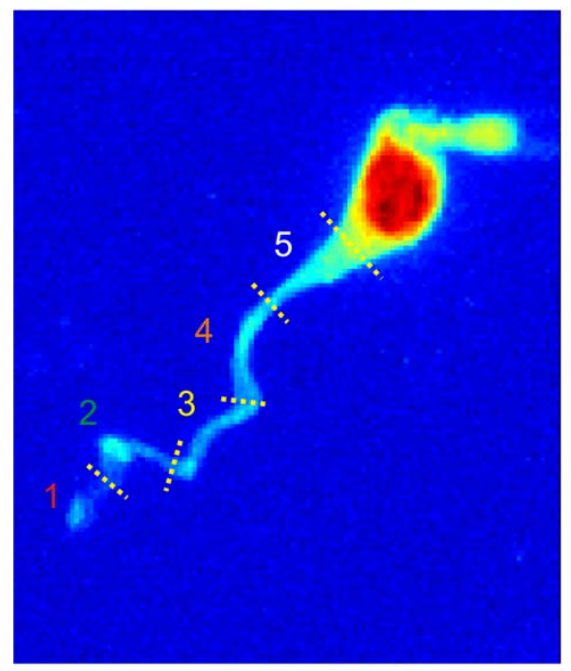

5

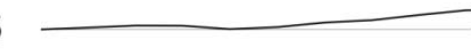

4

3

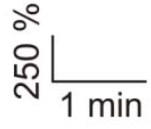

2

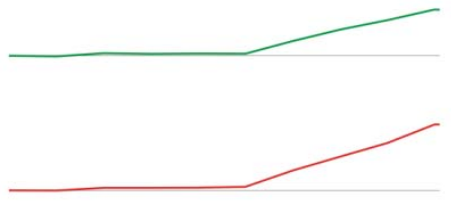

Figure 24: $\left[\mathrm{Ca}^{+2}\right]_{i}$ increases in the distal dendrite upon CE. Left side: fluo-4-loaded ORN with indicated regions of interest. Right: The $\left[\mathrm{Ca}^{2+}\right]_{\mathrm{i}}$ level upon $\mathrm{CE}$ was normalized to these of control conditions (grey line). $\left[\mathrm{Ca}^{2+}\right]_{\mathrm{i}}$ increased in all regions $2.5 \mathrm{~min}$ after CE wash-in. The increase was highest at the knob region (red trace) and smallest close to the soma (black region). Scale bars: $1 \mathrm{~min}$ and $\Delta \mathrm{F} / \mathrm{F}=250 \%$.

further reduced and additionally delayed the $\left[\mathrm{Ca}^{2+}\right]_{i}$ response. Wash-out with bath solution recovered the transient (Figure $23 \mathrm{E}$, blue trace; observed in 45 of 45 cells in three slices).

To localize the CB1/PMCA-mediated $\left[\mathrm{Ca}^{2+}\right]_{i}$ change in ORNs, single dendrites were imaged during $C E$ incubation of tissue slices. Exemplarily, a fluo-4-loaded cell is shown in Figure 24 (left side) as a z-projection. Regions of interest were arranged as indicated by the numbers. The $\left[\mathrm{Ca}^{2+}\right]_{\mathrm{i}}$ levels in these regions upon $\mathrm{CE}$ in the bath solution was normalized to those obtained during control conditions (five images accessed prior to the experiment, grey line). $\left[\mathrm{Ca}^{2+}\right]_{i}$ increased in all regions $2.5 \mathrm{~min}$ after CE wash-in, the increase was highest at the knob region (red trace) and smallest close to the soma (black region). Similar results were obtained for three cells. First experiments with the CB1 antagonist AM281 revealed similar results (data 

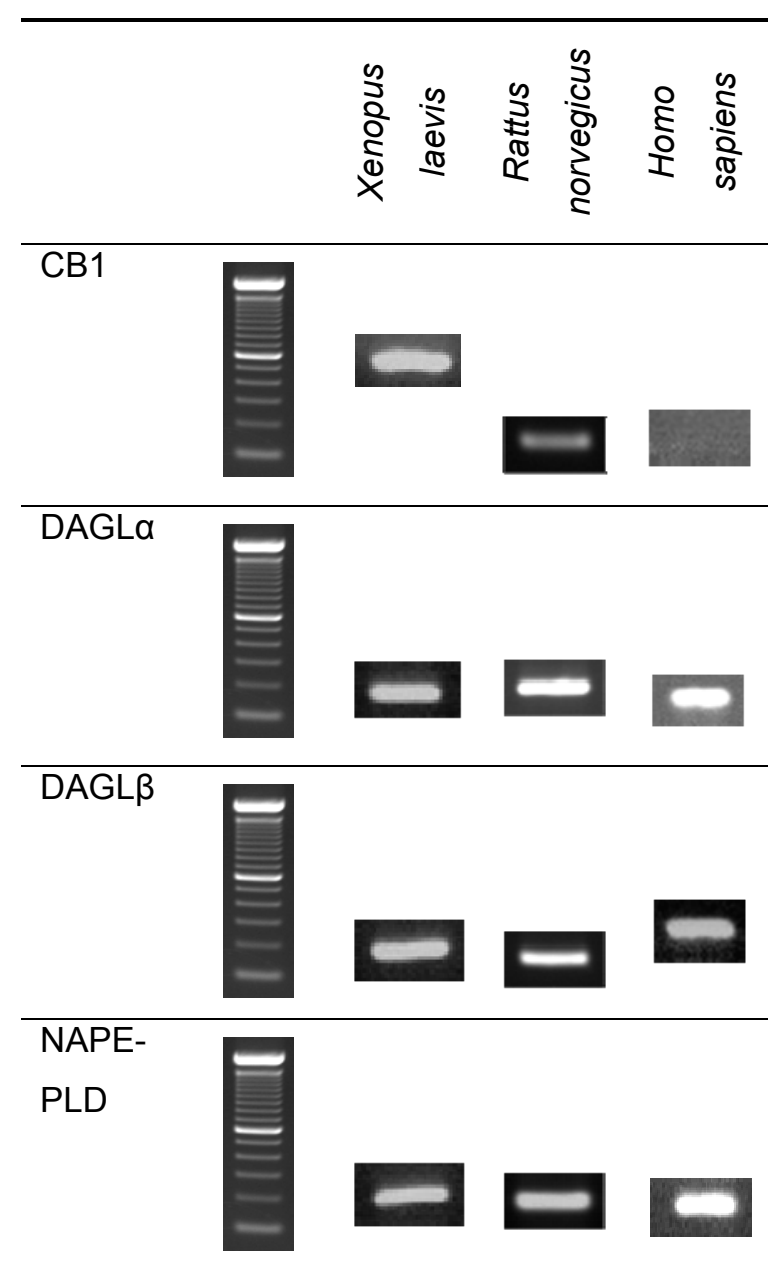

FAAH
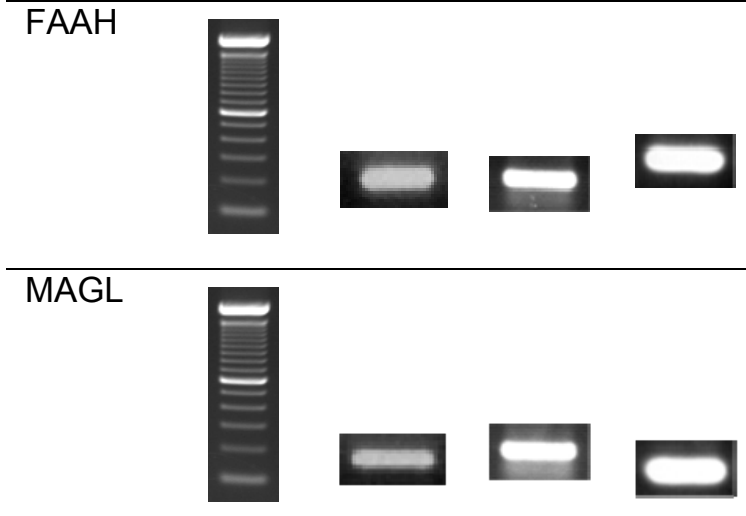

CB2
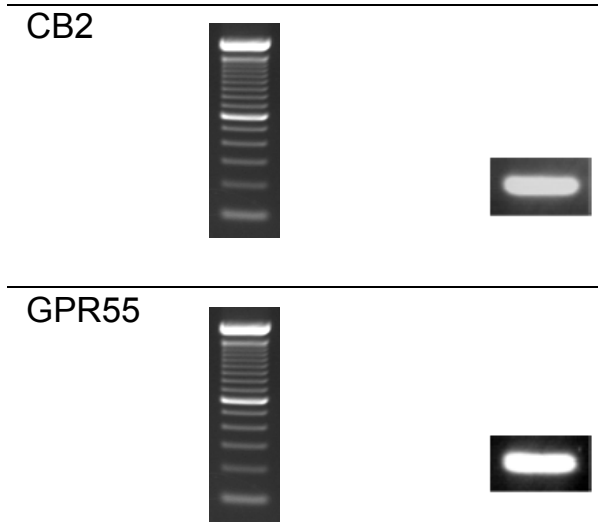
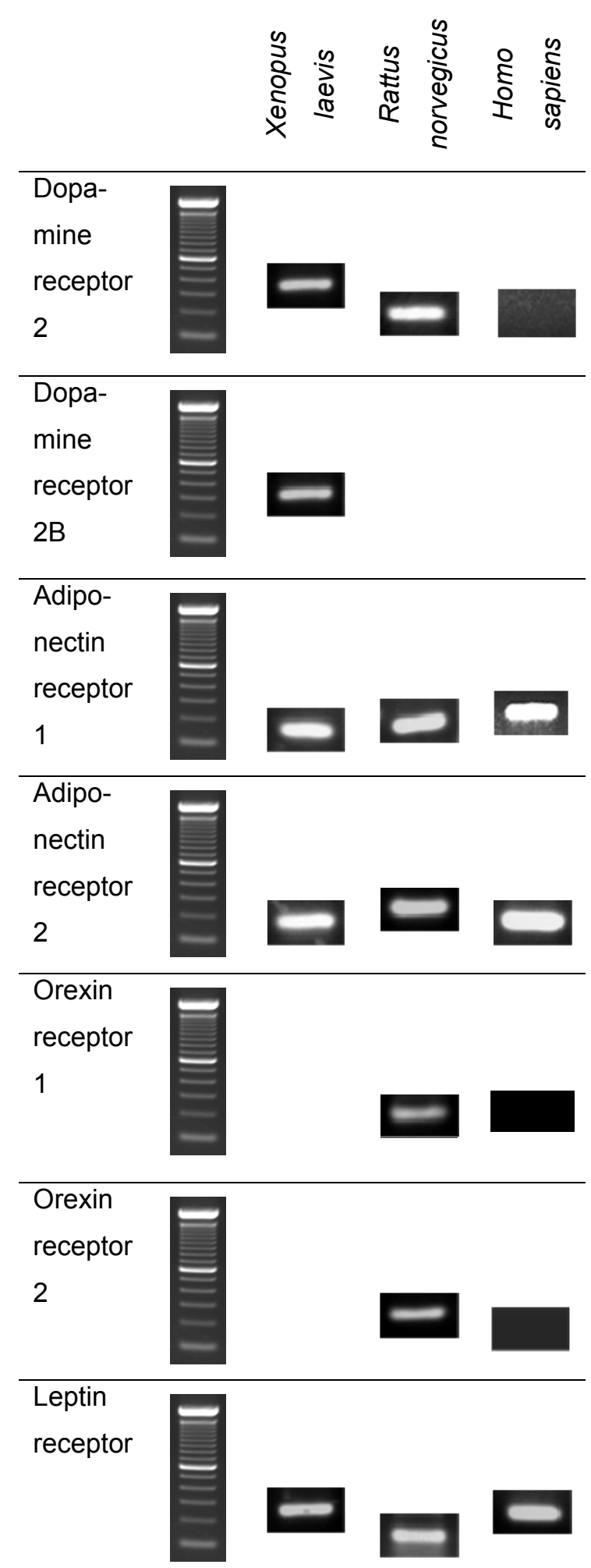
not shown; $n=3$ ). However, more experiments have to be carried out to draw a final conclusion.

\subsubsection{Endocannabinoid system and receptors for other modulators in the $\mathrm{OE}$ of various species}

Xenopus laevis tadpoles served as an animal model in all experiments so far. Of course, it is interesting to find out, if the endocannabinoid system is located also in mammals, especially in humans. Therefore, the mRNA in OEs of rats and a human was analyzed in addition to mRNA of tadpoles.

First, it was examined, whether mRNA for the synthesis and degradation enzymes for 2-AG (DAGLa, DAGL $\beta, F A A H$ ) and anandamide (NAPE-PLD, MAGL) are present in the OE (Table 6). In fact, PCR products for the corresponding mRNAs were detected in all samples investigated. CB1 receptor mRNA was detected in the $\mathrm{OE}$ of tadpoles and rats, but not in the human sample. In rats, CB2 receptor and GPR55 mRNA was additionally found. In humans, only GPR55 mRNA was detected as a receptor for endocannabinoids.

Since a link of the nutritious status to the endocannabinoid system in the $\mathrm{OE}$ was shown in this thesis (Figure 19), the presence of several receptors, among them receptors for orexigenic substances was investigated on the transcriptional level in OEs (Table 6). In tadpoles, the mRNA for dopamine, adiponectin, and leptin receptors were localized to the OE. Rats exhibited mRNA for dopamine, adiponectin, orexin, and leptin receptors in the $\mathrm{OE}$ and the human sample showed adiponectin and leptin receptor mRNA, but not dopamine and orexin receptor mRNA.

\footnotetext{
Table 6: mRNA of the components of the endocannabinoid system and receptors for other modulatory substances. In this table all investigated mRNAs of OEs of tadpoles $(n=$ $3)$, rats $(n=3)$, and a human $(n=1)$ are shown. Components of the endocannabinoid system (CB1, DAGLa, DAGL $\beta$, NAPE-PLD, FAAH, MAGL, CB2, GPR55) and receptors for orexigenic substances (dopamine receptors $A$ and $B$, adiponectin receptors 1 and 2, orexin receptors 1 and 2, leptin receptor) are listed. Empty table elements mirror mRNA, for which the gene sequence is not known or was not analyzed.
} 


\section{Discussion}

\subsection{The styryl dye FM1-43 permeates and blocks CNG channels in olfactory neurons of larval Xenopus laevis}

The first question I raised in the introduction was by which mechanisms odors are encoded by the activity of ORN subsets. An essential step toward solving this issue is to establish a tool in order to differentiate ORN subsets and to specifically interfere with one ORN subset pharmacologically. Here, the action of FM1-43 in the OE was investigated and the mechanism by which it acts was characterized.

\subsubsection{FM1-43 stains ORNs}

FM1-43, among other styryl dyes, is mainly used in the neurosciences to monitor membrane trafficking. Since this substance reversibly stains membranes but does not pass them, and because it changes its fluorescent properties according to the hydrophobicity of its environment, FM1-43 became a powerful tool to investigate synaptic vesicle recycling and synaptic transmission (Cochilla et al., 1999; Kidokoro et al., 2004; Kay et al., 1999). However, there are some studies, which describe the staining of neuronal cells by styryl dyes. FM1-43 labels several sensory and neuronal cells, e.g., sensory hair cells in the lateral line organ, the cochlea of various vertebrate species (Nishikawa and Sasaki, 1996; Seiler and Nicolson, 1999; Gale et al., 2001; Meyers et al., 2003), Merkel cells, taste buds, nociceptive fibers as well as primary sensory neurons in the trigeminal (V), geniculate (VII), petrosal (IX), nodose (X), and dorsal root ganglia (Meyers et al., 2003; Drew and Wood, 2007; Drew et al., 2007).

Nishikawa and Sasaki (1996) reported that FM1-43 labeled epidermal cells at nasal pits. The labeled cells were not further identified. Three years later, FM1-43 was shown to label dissociated ORNs (Rankin et al., 1999). In these experiments FM1-43 was internalized and appeared in the cell body, dendrite, and knob after 
stimulation with L-glutamate, but the dye could not be located to the cytosol or the plasma membrane due to technical reasons. Rankin et al. (1999) postulated a novel endocytosis-like mechanism for the dye uptake. In the present work, I found no evidence for this hypothesis. FM1-43 was shown herein to stain ORNs in the OE of Xenopus laevis tadpoles when living animals were incubated in a solution of distilled water and the dye (Figure 9). Fluorescence was observed in the cytosol and was absent only in the nucleus. The same cytosolic staining pattern as in this thesis was also observed for hair cells by Gale et al. (2001) and Meyers et al. (2003).

\subsubsection{FM1-43 uptake in ORNs through CNG channels}

Uptake of dyes through plasma membrane channels seems to be a more general process than previously assumed. For example, YO-PRO permeates purinergic receptors (Khakh et al., 1999) and TAE permeates the mechanoelectric transduction channel. Besides hair cell mechanotransducer channels, other sensory channels like the vanilloid receptor TRPV1, the purinergic receptor $\mathrm{P} 2 \mathrm{X}_{2}$ and mechanoelectric transduction channel of dorsal root ganglion cells (Meyers et al., 2003; Drew and Wood, 2007) were shown to be permeable for FM1-43.

Meyers and coworkers (2003) compared FM1-43 staining of hair cells with that of FM3-25, a structurally related styryl dye with similar properties. FM3-25 only labeled the plasma membrane of hair cells whereas FM1-43 caused a cytosolic staining. This comparison shows that FM1-43 stains certain cells by a different mechanism than membrane insertion, namely channel permeation.

For FM1-43 staining of ORNs, living tadpoles were incubated in a solution of the dye and distilled water. The cells at the apical side of the OE are connected by tight junctions that prevent the diffusion or the transport of molecules from the principal cavity into the tissue (Miragall et al., 1994; Steinke et al., 2008). Therefore, dye uptake certainly occurred through the plasma membrane exposed to the principal cavity: cilia, microvilli, and/or dendritic knobs come into consideration. Indeed, FM1-43 uptake in hair cells also occurred at the stereocilia (Gale et al., 2001; Meyers et al., 2003), where removal of the cilia prevented dye uptake. 
Since FM1-43 fluorescence was cytosolic, since it built up rapidly, and since CNG channels are located on cilia, it was checked whether CNG channels are permeable for FM1-43. The well-known permeability of divalent ions through CNG channels as well as the effect of two non-specific blockers of CNG channels were used here. FM1-43-staining of ORNs was blocked when divalent ions were present during dye internalization (Figure 11). Similarly, FM1-43 competes with other cations for uptake through the mechanoelectric transducer channel in hair cells (Nishikawa and Sasaki, 1996; Seiler and Nicolson, 1999; Gale et al., 2001).

Furthermore, the unspecific CNG channel blockers LY-83,583 and amiloride prevented dye uptake in ORNs as presented in this thesis (Figure 12). Endocytosisindependent FM1-43 uptake was also investigated by Meyers et al. (2003) in bullfrog and mice hair cells. In that study cells rapidly filled by diffusion of FM1-43 from the apical to the basal pole. Mechanical closure of the mechanotransducer channel was sufficient to block dye uptake. Gale and coworkers obtained similar results in 2001. Additionally, they demonstrated that hair cells of Myo 7a mutants cannot be labeled with FM1-43. In these mutants, the mechanoelectric transduction channels, and thus the gates for FM1-43 internalization, are closed at rest. In addition, treatment of hair cells with the $\mathrm{Ca}^{2+}$ chelator EGTA, a condition which breaks tip links and thus closes the mechanoelectric transduction channel, abolished subsequent dye loading.

In this study, FM1-43 entered ORNs in the absence of an externally applied stimulus. Generally, the exclusion of any kind of stimulation can hardly ever be met in olfactometry. Apart from this caveat, CNG channels in ORNs are reported to gate spontaneously and ligand-independent, thereby producing a detectable macroscopic conductance (Kaupp and Seifert, 2002). Kleene (2000) estimated the open probability of CNG channels due to spontaneous gating in dissociated grass frog ORNs to be approximately 0.03. Tibbs and coworkers (1997) calculated an open probability of 0.002 . Their model was an exogenous expression system with the $\alpha$ subunit of the catfish olfactory CNG channel. Combined with the incubation time of several minutes, this would allow spontaneous dye uptake in ORNs. This concept also holds true for hair cells: these can also be loaded with FM1-43 in the absence of a stimulus. The open probability of the mechanoelectric transduction channel at rest is 0.1 to 0.2 . A stimulus essentially increases the channel open probability and the current across the membrane (Grant and Fuchs, 2007). 


\subsubsection{Only ORNs endowed with the CAMP transduction machinery internalize FM1-43}

FM1-43 always stained a subset of ORNs in the OE. The identity of this subset was characterized herein by three experiments: First, FM1-43 staining of the ORN subset was blocked when divalent ions were present during dye internalization (Figure 11). Second, unspecific CNG channel blockers inhibited dye internalization (Figure 12). Third, FM1-43-stained ORNs exhibited the cAMP-dependent transduction cascade because they could be stimulated with forskolin and uncaging of cAMP (Figure 13).

These findings indicate that FM1-43 permeates CNG channels and stains ORNs with the cAMP-dependent transduction cascade. In a number of publications it has been reported that only a fraction of Xenopus laevis ORNs possess the canonical, cAMP-dependent olfactory transduction cascade (Manzini et al., 2002; Manzini et al., 2003b; Czesnik et al., 2006). Other ORNs in the OE detect odorants, e.g. amino acids, via a cAMP-independent transduction mechanism. FM1-43 must thus be supposed to stain cAMP-dependent ORNs when permeating CNG channels. Olfactory receptor neurons that could not be stained with FM1-43 are therefore believed to express a different kind of generator channel. If FM1-43 permeated those channels too, the vast majority of ORNs in the OE would be stained. As this was not the case, it can be concluded that the ORN generator channels involved in the detection of amino acids are not permeable for FM1-43.

In studies, in which hair cells were labeled with FM1-43, the staining was observed in all cells exposed to the dye (e.g. Seiler and Nicolson, 1999; Meyers et al., 2003). This may be due to the fact that the transduction mechanism in hair cells seems to be identical throughout the hair cell population in the cochlea. The identity of the mechanoelectric transduction channel is still unknown. However, it is a nonselective cation pore, permeable for $\mathrm{K}^{+}$and $\mathrm{Ca}^{2+}$ (Grant and Fuchs, 2007; Phillips et al., 2008). FM1-43 is thus used as a marker for mature hair cells (Doyle et al., 2007). 


\subsubsection{Extracellular FM1-43 inhibits cation currents through CNG channels}

To date, little systematic effort was made to develop potent and specific pharmacological agents that inhibit CNG channels. CNG channel blockers known so far are unspecific and have to be used in high concentrations causing many side effects. Others block channels only at positive membrane potentials. FM1-43 inhibits CNG channels at the resting membrane potential at low concentration (Figure 14). In the following, I will provide a short overview of CNG channel blockers with their properties concerning potency and specificity. Then, I will discuss FM1-43 as a CNG channel blocker:

L-cis-diltiazem is probably the CNG channel blocker, which has been studied most extensively (Koch and Kaupp, 1885; Haynes, 1992; Brown et al., 2006). It inhibits the rod photoreceptor CNG channels noncompetitively and in a voltagedependent manner. The $\mathrm{K}_{1 / 2}$ of L-cis-diltiazem is in the low micromolar range at $+30 \mathrm{mV}$ and increases with negative voltages. This blocker affects CNG channels from the cytoplasmatic side, and it is non-specific. Amiloride is often used as an epithelial $\mathrm{Na}^{+}$channel blocker at low micromolar concentrations, and it also blocks rod and olfactory CNG channels (used in Figure 12; Frings et al., 1992; Brown et al., 2006). The inhibition is strongly voltage-dependent and least effective at the resting membrane potential. D-600 and verapamil, two amiloride derivates, have similar properties (Frings et al., 1992). Dichlorobenzamil, another derivate of amiloride has more promising characteristics (Nicol et al., 1987). It blocks CNG channels at low micromolar concentrations, and it is relatively voltage-independent. Nevertheless, amiloride derivates cannot be considered as selective antagonists since they inhibit also the $\mathrm{Na}^{+}-\mathrm{Ca}^{2+}$ exchanger and voltage-gated $\mathrm{Na}^{+}, \mathrm{Ca}^{2+}$ and $\mathrm{K}^{+}$channels in the similar concentration range. LY-83,583 is another unspecific CNG channel blocker. It was used in this thesis at a high concentration (Figure 12). Besides this function, it blocks cGMP production, inhibits intracellular $\mathrm{Ca}^{2+}$ release, and blocks the effects of nitric oxide (Leinders-Zufall and Zufall, 1995). Tetracaine, a local anesthetic, blocks $\mathrm{Na}^{+}, \mathrm{Ca}^{2+}$ and $\mathrm{CNG}$ channels at micromolar concentrations. The block of CNG channels by tetracaine is voltage- and state-dependent. Two studies of Karpen's lab (Ghatpande et al., 2003; Strassmaier et al., 2005) reported on tetracaine analogues with less side effects. The most potent inhibitor for monomeric CNG channels is 
pseudechtoxin (Brown et al., 1999; Kaupp and Seifert, 2002). The $\mathrm{K}_{1 / 2}$ is 5 to $100 \mathrm{nM}$. Concerning heteromeric channels, the pseudechtoxin blocks CNG channels several odors of magnitudes less effectively.

Because of these unfavorable properties of the blockers, the concentrations of LY-83,583 and amiloride were very high (200 $\mu \mathrm{M}$ and $1 \mathrm{mM}$, respectively) in the presented experiment in Figure 12. Nevertheless, staining of ORNs with FM1-43 was abolished when these blockers were present.

In contrast to many CNG channel blockers mentioned above, FM1-43 blocks at resting membrane potentials. Cells can be stained in vivo without stimulation. Furthermore, $10 \mu \mathrm{M}$ FM1-43 reduced the CNG current to $\sim 25 \%$. This was measured in the absence of $\mathrm{Ca}^{2+}$ and $\mathrm{Mg}^{2+}$ at the resting membrane potential. The blockage occurred from the extracellular site as proven in Figure 15.

FM1-43 was also described as a blocker of cation currents in two other studies: Gale et al. (2001) observed that extracellular FM1-43 reversibly blocks mechanotransduction in cochlear hair cells in culture. FM1-43 reduces the currents in a voltage-dependent way. The block is most effective at $-4 \mathrm{mV}\left(\mathrm{K}_{\mathrm{d}}=1.2 \mu \mathrm{M}\right)$ and less effective at large positive and negative potentials. Furthermore, the block is strongly dependent on extracellular $\mathrm{Ca}^{2+}$ and most effective at low $\mathrm{Ca}^{2+}$ concentrations. In a study by Drew and Wood (2007) extracellular FM1-43 blocked rapidly- and slowlyadapting mechanically activated cation currents in cultured dorsal root ganglion neurons. The $\mathrm{K}_{d}$ is $5 \mu \mathrm{M}$ and $3 \mu \mathrm{M}$, respectively. The block was equally efficient at voltages of -70 and $-35 \mathrm{mV}$, but it was significantly reduced at positive holding potentials. At low extracellular $\mathrm{Ca}^{2+}$ concentrations the FM1-43 block of the currents was more effective.

With this knowledge, one of the first experiments I presented, i.e. the determination of odor sensitivity of FM1-43-loaded ORNs (Figure 10), becomes more comprehensible. Only few FM1-43-stained ORNs could be stimulated with an odormixture. The stimuli for these cells included amines and alcohols and elicited only very small $\left[\mathrm{Ca}^{2+}\right]_{i}$ transients. A second stimulation with the odors led to a reduced response. Considering these aspects, one can conclude that while permeating CNG channels FM1-43 blocks the ionic current through these channels. In this way odorant responses are prohibited. This is very useful as there are virtually no other potent and specific blockers for CNG channels known. 


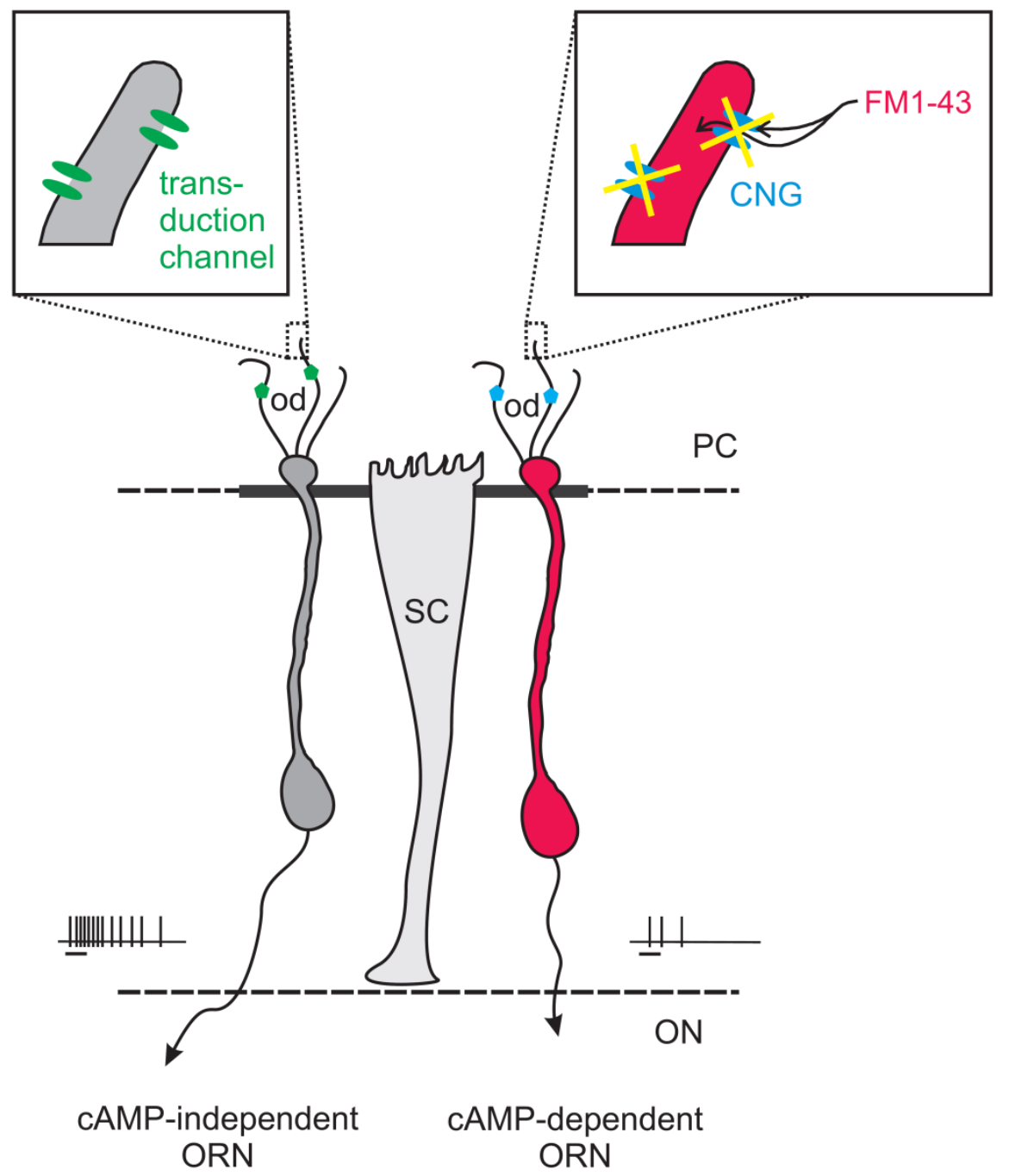

Figure 25: Action of FM1-43 in the OE. FM1-43 labels the ORN subset endowed with the cAMP-dependent transduction cascade (right side, ORN highlighted in red). Extracellular FM1-43 inhibits CNG channels. ORNs that use a different transduction mechanism and have a different generator channel are not stained with FM1-43 (left side, ORN in grey). PC, principal cavity; ON, olfactory nerve; od, odorant, SC, sustentacular cell. 


\subsubsection{Conclusion}

Taken together, FM1-43 appears to exert a permeation block of CNG channels (Figure 25). It is a novel mechanism to label a distinct subset of ORNs, and conversely, to identify non-labeled cells such as sustentacular cells or ORNs that don't use cAMP in their transduction cascade. Further it allows staining and blocking in vivo and under physiological conditions. It seems therefore particularly useful for studies of olfactory transduction cascades. Finally the fluorescence of FM1-43 may turn out to be well-suited for studying ciliary processes and channel densities. 


\subsection{Modulation of processing in olfactory receptor neurons by the endogenous cannabinoid system}

In the introduction, I pointed out that ORNs cannot be considered as static units. The physiological state of the organism may influence the fine-tuning of odor detection. Since many modulatory systems in the OE seem to work in parallel, one has to analyze all of these systems separately, and then investigate their interplay. Here I examined the effect of the endocannabinoid 2-AG on olfactory processing. In the following sections, I present the functional meaning of endocannabinoid modulation in the $\mathrm{OE}$, its action, and its mechanism of action.

\subsubsection{The endocannabinoid 2-AG acts in the OE}

Several studies showed that CB1 receptors or the related mRNA can be found at different stages of the central olfactory system (Cesa et al., 2001; Egertová and Elphick, 2000). A study of Migliarini et al. (2006) demonstrated the presence of CB1 receptor mRNA in the OE of Xenopus laevis tadpoles at stage 46. Recently, Czesnik and coworkers (2007) revealed that ORNs are modulated by cannabinoids. CB1 receptor antagonists reduced and delayed odor-induced responses of ORNs, and the CB1 receptor agonist HU210 accelerated the recovery of these responses. Additionally, they localized CB1 receptors on ORN dendrites in the OE. These results indicate the presence of the endogenous cannabinoid system in the OE. However, the type of endocannabinoid acting in the OE was not described. Therefore, an mRNA analysis of the components of the endocannabinoid system in the OE of tadpoles was performed. Indeed, mRNA of the CB1 receptor as well as the synthesis and degradation enzymes for 2-AG (DAGLa, DAGL $\beta, M A G L)$ and anandamide (NAPE-PLD, FAAH) were detected (Figure 16). This implies that both 2-AG and anandamide are synthesized in the OE.

2-AG is more abundant in the brain than anandamide (Sugiura et al., 2006). For this reason, its action was investigated by blockage of 2-AG synthesis with the DAGL inhibitors RHC80267 or orlistat (Hashimotodani et al., 2008) in the present 
work. This decreased and delayed the odor-induced $\left[\mathrm{Ca}^{2+}\right]_{i}$ transients. Wash-in of the CB1 receptor agonist HU210 rescued the responses (Figure 17). The same effects were obtained with the CB1 receptor antagonists AM281, AM251, and LY320135 by Czesnik and coworkers (2007).

Besides the olfactory system, other sensory systems are also known to be modulated by the endocannabinoid system. For example, CB1 receptors are located on photoreceptors and bipolar cells in the visual system. There, cannabinoids speed up the dynamics of the phototransduction deactivation cascade in cones (Straiker et al., 1999; Struik et al., 2006). In addition, CB1 receptors are expressed on dorsal root ganglion cells, and may play a role in the spinal nociceptive system (Morisset et al., 2001). The endocannabinoid modulation of sensory output at the most peripheral stage may thus be a common feature of these sensory systems.

\subsubsection{Cellular localization of 2-AG synthesis and its functional meaning}

2-AG acts in the OE, and it is synthesized by DAGL $\alpha$ and $\beta$. However, the cellular localization of 2-AG synthesis was not known so far. In this thesis, mRNA of both the DAGL $\alpha$ and $\beta$ isoforms were detected by single-cell PCR in sustentacular cells and ORNs, respectively (Figure 18). In ORNs appears to exist an autocrine pathway since 2-AG is produced by DAGL $\beta$ in ORNs, and since it acts on CB1 receptors on ORNs (Czesnik et al., 2007). In contrast, DAGLa mRNA is solely expressed in sustentacular cells, indicating an additional paracrine route of 2-AG action in the OE.

2-AG production by DAGLa in sustentacular cells is enhanced upon food-deprivation 2-AG is produced by DAGLa in sustentacular cells and acts paracrine on ORN dendrites. Sustentacular cells insulate ORNs (Breipohl et al., 1974; Getchell and Getchell, 1992; Farbman, 1992; Morrison and Moran, 1995) and regulate mucus secretion and ion homeostasis of the extracellular compartment (Getchell and Getchell, 1992; Hansen et al., 1998). In this thesis, a novel role of sustentacular cells is indicated. 2-AG is secreted by sustentacular cells and modulates the activity of ORNs. Additionally, DAGLa mRNA expression in the OE was found to be enhanced after food deprivation, whereas DAGL $\beta$ expression was not affected by the various 
nutritious conditions (Figure 19). This allows to conclude that 2-AG production in sustentacular cells by DAGLa is enhanced by hunger and acts via a paracrine route upon CB1 receptors on ORN dendrites.

The endocannabinoid system is known to play a crucial role in food intake and energy homeostasis (Aimé et al., 2007). For instance, in the teleost fish Carassius auratus (Soderstrom et al., 2004), in the zebra finch (Kirkham et al., 2002), and in rodents (Di Marzo et al., 2001; McLaughlin et al., 2003), brain endocannabinoids seem to act as orexigenic mediators. In addition, AM251 induces suppression of rat food intake and food-reinforced behavior in rats (Mousley et al., 2006). The link between exocannabinoids and increased food intake is well-known (Hart et al., 2002; Verty et al., 2005). A previous study has shown that CB1 receptor antagonists diminish and delay odor responses (Czesnik et al., 2007). In this thesis, a functional link between 2-AG as a modulator in the OE and the nutritious state of an animal is shown. It was demonstrated that there is an endocannabinoid-system-mediated crosstalk between the neuronal control of feeding, e.g. olfaction, and the nutritional state.

A similar concept was suggested for orexin and leptin, which are hormones involved in energy metabolism. Orexins are synthesized within the OE. Orexin receptors were localized among others on the apical part and microvilli of sustentacular cells and knobs and cilia of ORNs in the OE. Thus, a possible modulation of olfactory perception by these neuropeptides is probable (Caillol et al., 2003). Intranasally applied orexin A restores olfactory function in narcolepsy (Baier et al., 2008), and more importantly, cerebroventricular injection of orexin results in an increased olfactory sensitivity (Julliard et al., 2007). Leptin and its receptors were also found on sustentacular cells and ORNs (Baly et al., 2007). Fasting caused a significantly enhanced transcription of both leptin and leptin receptors. Furthermore, leptin decreases odor-induced receptor potentials (Savigner et al., 2009) and sensitivity in a behavioral experiment (Julliard et al., 2007). 
2-AG produced by DAGL $\beta$ in ORNs may play a role in ORN protection or differentiation

2-AG is also produced by DAGL $\beta$ in ORNs and acts autocrine on CB1 receptors on ORN dendrites. As to the autocrine pathway, no particular modulation was found. However, the following two functional meanings could be plausible:

First, odor-induced increase of $\left[\mathrm{Ca}^{2+}\right]_{i}$ can be supposed to mediate 2-AG release (as reported in other systems, Szabo et al., 2006; Hashimotodani et al., 2007) and a subsequent increase of sensitivity and signal-to-noise ratio of responses to odors.

Second, autocrine endocannabinoid signaling appears to be a key regulatory signaling network for the wiring of the brain during development (Harkany et al., 2008), and may play a role in the constantly regenerating ORNs (Schwob, 2002) in the OE. Interference with the endocannabinoid system using pharmacological inhibitors disturbs axon pathfinding and fasciculation (Watson et al., 2008). Williams and coworkers showed that DAGL-dependent activation of neuronal CB1 receptors and $\mathrm{CB} 1$ agonists stimulate the growth of axons while CB1 antagonists inhibit this process (Williams et al., 2003). For instance, developing pyramidal cells rely on endocannabinoid signaling to initiate the elongation and fasciculation of their longdistance axons (Mulder et al., 2008).

In the future, selective blockers will allow to study the effect of autocrine acting 2-AG, which is produced by DAGL $\beta$.

\subsubsection{2-AG level modulates odor detection thresholds}

Recently, several studies dealing with the influence of the nutritious state on the neurophysiology of olfactory information processing have been published. In these studies an altered sensitivity of ORNs could indirectly be attributed to the effects of modulators like neuropeptide $\mathrm{Y}$, leptin or orexin (Mousley et al., 2006; Caillol et al. 2003; Getchell et al., 2006). Here, detection thresholds of arginine, lysine, and methionine were investigated. Their dose-response relationships and detection thresholds at cellular resolution were described using confocal fluo- $4 \mathrm{Ca}^{2+}$-imaging (Figure 20). The findings show that response thresholds are distributed over a 
distinct concentration range between 0.2 and $200 \mu \mathrm{M}$, which has also been described by Duchamp-Viret and coworkers for ORNs in rat and adult frog (Duchamp-Viret et al., 2000). The classical view is that odorant detection thresholds are determined by the affinity and expression level of olfactory receptors (Kajiya et al., 2001; Malnic et al., 1999; Saito et al., 2009), olfactory receptor dimerization (Neuhaus et al., 2004) as well as amplification and adaptation in the transduction cascade (Takeuchi and Kurahashi, 2008). Herein, the significant contribution of endocannabinoids to the control of odorant thresholds is shown (Figure 21, Figure 22). These findings support the view that 2-AG acts as an orexigenic modulator in the OE by increasing and decreasing the sensitivity of ORNs to odorants during phases of hunger or satiety. As a consequence, the concept of a "threshold as a well defined and constant concentration below which an ORN does not respond to a specific odorant" is no longer applicable. The threshold under control conditions, $\mathrm{c}_{\mathrm{th}}$, as it has been used herein, may serve as a simple and convenient definition, but it should only be used if the conditions are sufficiently well-defined.

\subsubsection{Novel CB1 transduction cascade in ORNs: PMCA as effector molecule}

The preliminary results concerning the transduction mechanism of $\mathrm{CB} 1$ receptors suggest (Figure 23, Figure 24) that the PMCA is involved in $C B 1$ signaling. CB1 receptor activation would enhance PMCA activity and thus decrease $\left[\mathrm{Ca}^{2+}\right]_{\mathrm{i}}$ whereas CB1 blockage would reduce PMCA activity and thus increase $\left[\mathrm{Ca}^{2+}\right]$. The changes in $\left[\mathrm{Ca}^{2+}\right]_{\mathrm{i}}$ levels could be localized to the apical dendrite and knob in the experiments performed and will be verified in future experiments. It is known, that CB1 receptor activation modulates $\left[\mathrm{Ca}^{2+}\right]_{i}$ (e.g. Straiker et al.,1999; Huang et al., 2001; Mackie et al., 1995). However, the PMCA as an effector molecule of the CB1 receptor in ORNs would propose a novel mechanism of $\mathrm{CB} 1$ receptor signaling. Certainly, the messengers in between the CB1 receptor and the PMCA still have to be identified.

Another question, which has to be solved in a future study is, how altered $\left[\mathrm{Ca}^{2+}\right]_{i}$ levels in ORNs mediate the reduction and the delay of odorant-evoked $\left[\mathrm{Ca}^{2+}\right]_{i}$ transients. One hypothesis is that changes in $\left[\mathrm{Ca}^{2+}\right]_{i}$ induced by PMCA may affect 
olfactory transduction by mimicking an adaptative state of the respective ORN to odorants and thus modulate ORN sensitivity. Three different types of adaptation for which elevated $\left[\mathrm{Ca}^{2+}\right]_{\mathrm{i}}$ is crucial, were described for ORNs. First, $\mathrm{Ca}^{2+}$-calmodulin binding to the CNG channel decreases its affinity for CAMP. For this reason an equal stimulus results in smaller responses (Chen and Yau, 1994; Liu et al., 1994). Second, $\mathrm{Ca}^{2+}$-activated calmodulin-dependent protein kinase II inhibits the adenylate cyclase III by phosphorylation and attenuates odorant responses (Wei et al., 1998; Leinders-Zufall et al., 1999). Third, $\mathrm{Ca}^{2+}$-activated calmodulin-dependent protein kinase II targets the phosphodiesterase $1 \mathrm{C}$, which then probably enhances cAMP destruction (Yan et al., 1995; Borisy et al., 1992).

Further experiments will elucidate the CB1 transduction cascade in ORNs and the effect of CB1-receptor induced $\left[\mathrm{Ca}^{2+}\right]_{i}$ changes by PMCA in ORNs.

\subsubsection{Endocannabinoid and other modulatory systems exist in the OE of Xenopus laevis tadpoles and mammals}

In this thesis, it was demonstrated that the action of 2-AG controls detection thresholds of odorants in larval Xenopus laevis. Subsequently, it was investigated, whether the $\mathrm{OE}$ of higher vertebrates also exhibit the equipment of the endocannabinoid system. For this experiment, samples of rats and a human were used.

The mRNA for the enzymes for production and degradation of 2-AG as well as anandamide were detected in rat and human. The CB1 and CB2 receptor were only found in rats, but GPR55 was detected in both species (Table 6). GPR55 is an orphan G protein-coupled receptor and was recently proposed as a novel cannabinoid receptor with different pharmacological properties than CB1 and CB2 receptors (Barnett-Norris et al., 2005; Brown, 2007; Pertwee, 2007). Hence, the components or similar components of the endocannabinoid system found in larval Xenopus laevis also exist in the OE of rat and human. In order to speculate about similarities between the physiological meaning of endocannabinoids in the OE of larval Xenopus laevis and mammals, further experiments have to be done. 
Recently, several studies revealed other neuromodulatory substances like orexin, leptin, adiponectin, and dopamine. Orexin, leptin, and adiponectin are hormones involved in food intake and energy metabolism, and act orexigenic or anorexigenic. Orexin and leptin are synthesized in the OE (Caillol et al., 2003; Baly et al., 2007) whereas adiponectin reaches the OE with the blood serum (Hass et al., 2008). Dopamine acts neuroprotectively in the OE, probably by binding to D2 receptors (Hegg and Lucero, 2004). The source of dopamine is not identified yet. However, all described substances have their corresponding receptors on ORNs and probably influence olfactory transduction. Odorant transduction and coding seems to be a complex, highly dynamic process. Olfactory receptor neurons are thus not only tuned by 2-AG, as demonstrated in detail in this thesis, but also by many other substances. To gain first hints if these systems indeed exist in parallel within the $\mathrm{OE}$ of one animal, mRNA of OEs of larval Xenopus laevis, rats, and the human were screened for receptors of orexin, leptin, adiponectin, and dopamine.

In tadpoles, mRNA for dopamine, adiponectin, and leptin receptors were found (the genetic identity for the orexin receptor is not known so far). Rats exhibit mRNA for dopamine, adiponectin, orexin, and leptin receptors. The human sample showed adiponectin as well as leptin receptor mRNA, but neither dopamine nor orexin receptor mRNA (Table 6). These data demonstrate that the morphological basis for a complex modulatory signaling system is present in all three species. To date it is not known how these systems act, and whether they interact with the endocannabinoid system. However, in the literature there are some hints for possible interplays of these systems:

Peptides such as leptin, adiponectin, and orexin modulate food intake, and act on the endocannabinoid system. Consistently, it was shown that leptin treatment of mice affects 2-AG signaling in the thalamus (Di Marzo et al., 2001; Jo et al., 2005). A functional link between adiponectin and endocannabinoids was observed by Zyromski et al. (2009). In that study, CB1 receptor blockade increased circulating adiponectin concentration. Crespo and coworkers (2008) demonstrated that the CB1 receptor antagonist rimonabant blocks the orexigenic effect of orexin. The receptor for orexin belongs to the family of $\mathrm{G}_{\mathrm{q} / 11}$ protein-coupled receptors (Sakurai et al., 1998). These receptors have the potential to stimulate endocannabinoid production through receptor-driven endocannabinoid release or $\mathrm{Ca}^{2+}$-assisted 
receptor-driven endocannabinoid release (Hashimotodani et al., 2007; Kano et al., 2009). Thus, orexin may be a trigger for endocannabinoid release in the OE.

Another type of interaction between dopamine and orexin on the one hand and endocannabinoids on the other is receptor heterodimerization of the respective receptor with the CB1 receptor (Mackie, 2005). CB1 receptors and D2 receptors can form dimers with antagonistic interactions (Marcellino et al., 2008). Furthermore, CB1 and orexin receptors can dimerize (Hilairet et al., 2003; Ellis et al., 2006).

Many modulatory systems exist in the OE. Their roles and their possible interfaces have to be investigated by physiological experiments in future studies. The presence of various modulatory systems in the OE and the few studies indicating first functional links open the novel field of peripheral modulation of olfactory input.

\subsubsection{Conclusions}

To summarize, the findings support the view that paracrine 2-AG acts as an orexigenic modulator in the OE by increasing and decreasing the sensitivity of ORNs to odorants during phases of hunger or satiety (Figure 26). As a consequence, the concept of a "threshold as a well defined and constant concentration below which an ORN does not respond to a specific odorant" has lost its meaning. PMCA probably acts as the effector molecule of the CB1 receptor and alters the intracellular $\mathrm{Ca}^{2+}$ concentration according to the 2-AG level in the OE. This would be a novel signaling mechanism of the CB1 receptor and a future study will reveal the cascade in detail. Besides endocannabinoids, also other modulatory substances may act in the OE. 


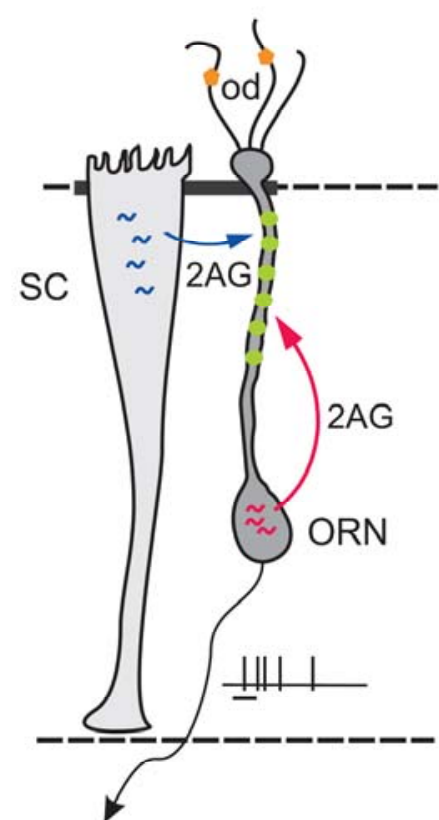

control

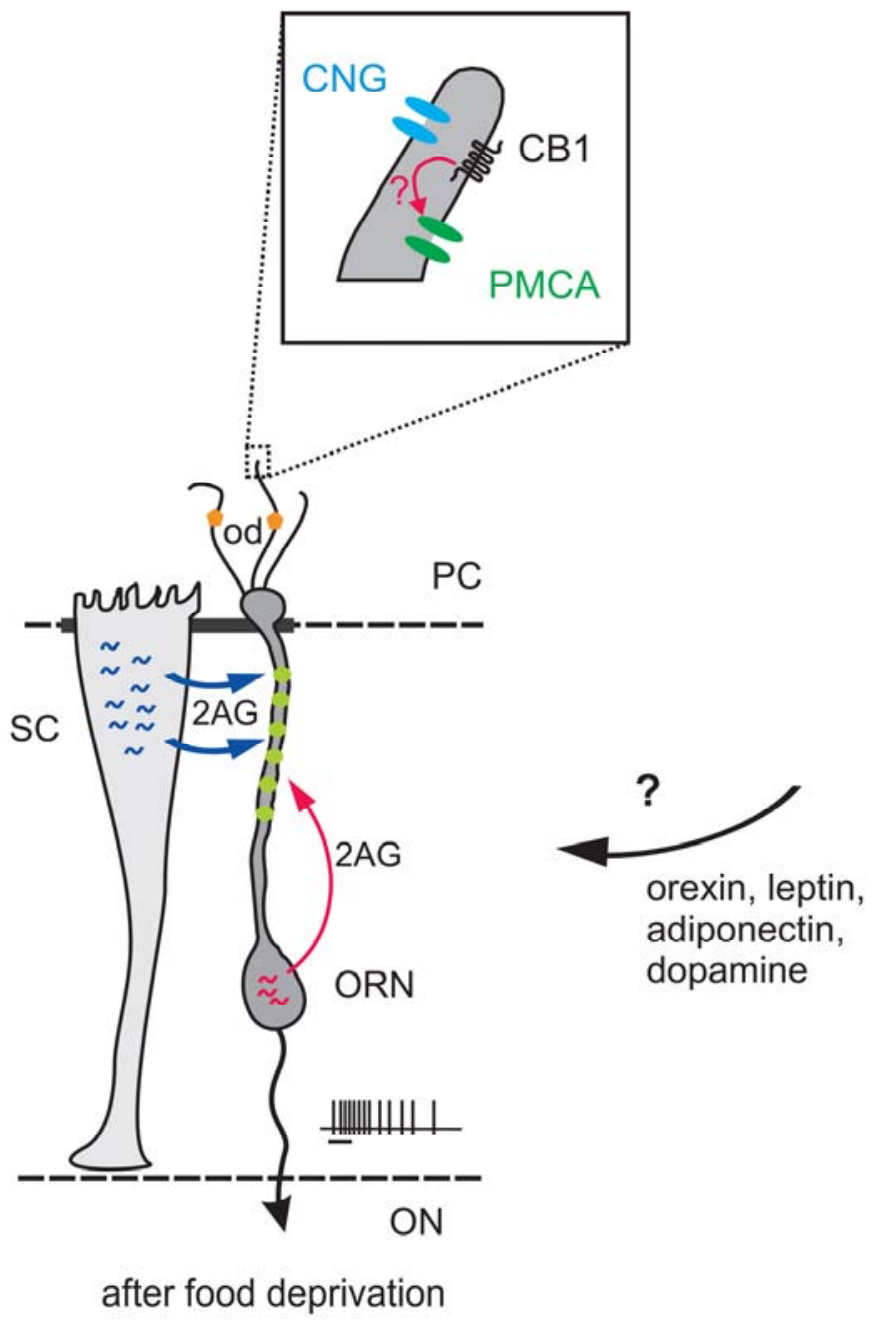

Figure 26: Scheme of endocannabinoid action in the OE. Under control conditions a tonic level of 2-AG is synthesized. DAGLa mRNA synthesis in sustentacular cells ( , blue) is enhanced upon food-deprivation and leads to an enhanced level of 2-AG binding to CB1 receptors (green circles) on ORN dendrites (blue arrows). This state renders ORNs more sensitive and increases action potential frequency. DAGL $\beta$ mRNA expression in ORNs $(\sim$, red) is not affected upon food-deprivation. 2-AG synthesized in ORNs feeds back on ORNs (red arrow). The CB1 receptor probably alters PMCA activity. Also other substances like orexin, leptin, adiponectin, and dopamine may modulate ORN activity. PC, principal cavity; ON, olfactory nerve; od, odorant; SC, sustentacular cell. 


\section{Summary}

The sense of smell is critical for finding food and mediating emotional and social responses. A dysfunction of this sense is often associated with diseases. In the last two decades much progress has been made in this research field and insights in how the sensation of smell is perceived has been gained. This thesis covers two topics of basic research in olfaction and is accordingly subdivided:

1. Various olfactory receptor neuron subsets exist in the olfactory epithelium. One classification of these subsets can be made according to the transduction mechanism of odorants. The olfactory receptor neurons belonging to one subset transduce odorants into depolarizations using the cAMP-dependent transduction mechanism. To date, it is not possible to stain this subset or to interfere with their generator channels with potent and specific blockers. In this thesis, the styryl dye FM1-43 was identified as a marker for olfactory receptor neurons endowed with cAMP-dependent transduction machinery. The dye is internalized in neurons by uptake through cyclic nucleotide-gated channels, the generator channel of the CAMP-dependent olfactory receptor neurons. This was proven by interference of FM1-43 uptake with divalent ions and unspecific cyclic nucleotide-gated channel blockers used in high concentrations and further confirmed by evoking responses to cAMP and forskolin in FM1-43-stained cells. Characteristic for FM1-43-stained olfactory receptor neurons is that these cells did not respond to odors or rapidly lost their responsiveness. This suggested that FM1-43 severely interfered with the transduction machinery of stained olfactory receptor neurons. Indeed, $10 \mu \mathrm{M}$ FM1-43 blocked currents through native cyclic nucleotide-gated channels to approximately $25 \%$ and acts from the extracellular side. This tool thus allows optical differentiation and pharmacological interference with olfactory receptor neurons endowed with cAMP-dependent transduction at the level of the signal transduction. 
2. The sense of smell is an important input for the search for food and food intake, but the underlying mechanisms for this functional interaction are poorly understood. One key factor for energy homeostasis and nutrition at central stages is the endocannabinoid system. Therefore, it was hypothesized, that the endocannabinoid system may link food intake with olfaction. Recently, cannabinoids were shown to act in the olfactory epithelium. Pharmacological interference at the according cannabinoid receptor modulates odor-evoked responses. In this thesis, it is shown that the endocannabinoid 2-AG is synthesized in the olfactory epithelium and acts on olfactory receptor neurons. Blocking 2-AG synthesis decreased and delayed odorant-induced responses. Analyzing single cells revealed, that there are two sources of 2-AG in the olfactory epithelium: the first are olfactory receptor neurons, where production of 2-AG depends on diacylglycerol lipase $\beta$, and the other are sustentacular cells, where production depends on diacylglycerol lipase $\alpha$. Diacylglycerol lipase a mediated 2-AG-synthesis in sustentacular cells is influenced by the hunger state of the animal. The essential 2-AG effect in olfactory receptor neurons is the control of odorant detection thresholds. An enhanced 2-AG level decreases the detection threshold of an individual olfactory receptor neuron whereas a lowered 2-AG level increases the detection threshold. Thus, hunger renders olfactory receptor neurons more sensitive and endocannabinoid modulation in the nose may therefore substantially influence food seeking behavior. The intracellular effector mediating cannabinoid receptor actions probably is the plasma membrane calcium ATPase. This signaling cascade was not described as yet. However, future experiments have to be performed to identify the complete transduction cascade. Besides the endocannabinoid system, receptors for several other modulatory substances, i.e. orexin, leptin, adiponectin, and dopamine, were found in the olfactory epithelium. This indicates that already at the most peripheral stage of the olfactory system, the sensation of odors is modulated by many substances. 


\section{References}

Adams IB and Martin BR (1996) Cannabis: pharmacology and toxicology in animals and humans. Addiction 91:1585-1614.

Aimé $\mathrm{P}$, Duchamp-Viret $\mathrm{P}$, Chaput MA, Savigner A, Mahfouz $M$ and Julliard AK (2007) Fasting increases and satiation decreases olfactory detection for a neutral odor in rats. Behav Brain Res 179:258-264.

Altner H, Sass H and Altner I (1977) Relationship between structure and function of antennal chemo-, hygro-, and thermoreceptive sensilla in Periplaneta americana. Cell Tissue Res 176:389-405.

Atanasova B, Graux J, El Hage W, Hommet C, Camus V and Belzung C (2008) Olfaction: a potential cognitive marker of psychiatric disorders. Neurosci Biobehav Rev 32:1315-1325.

Avila VL and Frye PG (1978) Feeding behavior of the African Clawed frog (Xenopus laevis Daudin): effect of prey type. J Herpetol 12:391-396.

Baier PC, Weinhold SL, Huth V, Gottwald B, Ferstl R and Hinze-Selch D (2008) Olfactory dysfunction in patients with narcolepsy with cataplexy is restored by intranasal Orexin A (Hypocretin-1). Brain 131:2734-2741.

Baly C, Aioun J, Badonnel K, Lacroix MC, Durieux D, Schlegel C, Salesse R and Caillol M (2007) Leptin and its receptors are present in the rat olfactory mucosa and modulated by the nutritional status. Brain Res 1129:130-141.

Barnett-Norris J, Lynch D and Reggio PH (2005) Lipids, lipid rafts and caveolae: their importance for GPCR signaling and their centrality to the endocannabinoid system. Life Sci 77:1625-1639.

Basavarajappa BS (2007) Critical enzymes involved in endocannabinoid metabolism. Protein Pept Lett 14:237-246.

Benos DJ (1982) Amiloride: a molecular probe of sodium transport in tissues and cells. Am J Physiol 242:C131-145. 
Borisy FF, Ronnett GV, Cunningham AM, Juilfs D, Beavo J and Snyder SH (1992) Calcium/calmodulin-activated phosphodiesterase expressed in olfactory receptor neurons. J Neurosci 12:915-923.

Bouaboula M, Poinot-Chazel C, Bourrié B, Canat X, Calandra B, Rinaldi-Carmona M, Le Fur $G$ and Casellas P (1995) Activation of mitogen-activated protein kinases by stimulation of the central cannabinoid receptor CB1. Biochem J 312:637-641.

Bouvet JF, Delaleu JC and Holley A (1988) The activity of olfactory receptor cells is affected by acetylcholine and substance P. Neurosci Res 5:214-223.

Breer H and Shepherd GM (1993) Implications of the NO/cGMP system for olfaction. Trends Neurosci 16:5-9.

Breipohl W, Laugwitz HJ and Bornfeld N (1974) Topological relations between the dendrites of olfactory sensory cells and sustentacular cells in different vertebrates. An ultrastructural study. J Anat 117:89-94.

Broillet MC and Firestein S (1996) Gaseous second messengers in vertebrate olfaction. J Neurobiol 30:49-57.

Brown AJ (2007) Novel cannabinoid receptors. Br J Pharmacol 152:567-575.

Brown RL, Haley TL, West KA and Crabb JW (1999) Pseudechetoxin: a peptide blocker of cyclic nucleotide-gated ion channels. Proc Natl Acad Sci U S A 96:754759.

Brown RL, Strassmaier T, Brady JD and Karpen JW (2006) The pharmacology of cyclic nucleotide-gated channels: emerging from the darkness. Curr Pharm Des 12:3597-3613.

Bruch RC (1996) Phosphoinositide second messengers in olfaction. Comp Biochem Physiol B Biochem Mol Biol 113:451-459.

Buck $L$ and Axel R (1991) A novel multigene family may encode odorant receptors: a molecular basis for odor recognition. Cell 65:175-187.

Byrd CA and Burd GD (1991) Development of the olfactory bulb in the clawed frog, Xenopus laevis: amorphological and quantitative analysis. J Comp Neurol 314:7990. 
Caillol M, Aïoun J, Baly C, Persuy MA and Salesse R (2003) Localization of orexins and their receptors in the rat olfactory system: possible modulation of olfactory perception by a neuropeptide synthetized centrally or locally. Brain Res 960:48-61.

Caprio J and Byrd RP Jr (1984) Electrophysiological evidence for acidic, basic, and neutral amino acid olfactory receptor sites in the catfish. J Gen Physiol 84:403422.

Carr WES and Derby CD (1986) Chemically stimulated feeding behavior in marine animals. Importance of chemical mixtures and involvement of mixture interactions. J Chem Ecol 12:989-1011.

Carr WES, Trapido-Rosenthal HG and Gleeson RA (1990) The role of degradative enzymes in chemosensory processes. Chem Senses 15:181-190.

Castillo K, Delgado R and Bacigalupo J (2007) Plasma membrane $\mathrm{Ca}^{2+}$-ATPase in the cilia of olfactory receptor neurons: possible role in $\mathrm{Ca}^{2+}$ clearance. Eur $\mathrm{J}$ Neurosci 26:2524-2531.

Cesa R, Mackie K, Beltramo M and Franzoni MF (2001) Cannabinoid receptor CB1like and glutamic acid decarboxylase-like immunoreactivities in the brain of Xenopus laevis. Cell Tissue Res 306:391-398.

Chen TY and Yau KW (1994) Direct modulation by $\mathrm{Ca}^{2+}$-calmodulin of cyclic nucleotide-activated channel of rat olfactory receptor neurons. Nature 368:545548.

Childers SR and Deadwyler SA (1996) Role of cyclic AMP in the actions of cannabinoid receptors. Biochem Pharmacol 52:819-827.

Cochilla AJ, Angleson JK and Betz WJ (1999) Monitoring secretory membrane with FM1-43 fluorescence. Annu Rev Neurosci 22:1-10.

Crespo I, Gomez de Heras R, Rodriguez de Fonseca F and Navarro M (2008) Pretreatment with subeffective doses of Rimonabant attenuates orexigenic actions of orexin A-hypocretin 1. Neuropharmacology 54:219-225.

Czesnik D, Kuduz J, Schild D and Manzini I (2006) ATP activates both receptor and sustentacular supporting cells in the olfactory epithelium of Xenopus laevis tadpoles. Eur J Neurosci 23:119-128. 
Czesnik D, Schild D, Kuduz J and Manzini I (2007) Cannabinoid action in the olfactory epithelium. Proc Natl Acad Sci U S A 104:2967-2972.

Demuth DG and Mollemann A (2006) Cannabinoid signaling. Life Sci 78:549-563.

Devane WA, Hanus L, Breuer A, Pertwee RG, Stevenson LA, Griffin G, Gibson D, Mandelbaum A, Etinger A and Mechoulam R (1992) Isolation and structure of a brain constituent that binds to the cannabinoid receptor. Science 258:1946-1949.

Dhallan RS, Yau KW, Schrader KA and Reed RR (1990) Primary structure and functional expression of a cyclic nucleotide-activated channel from olfactory neurons. Nature 347:184-187.

Di Marzo V, Bifulco M and De Petrocellis L (2004) The endocannabinoid system and its therapeutic exploitation. Nat Rev Drug Discov 3:771-784.

Di Marzo V, Goparaju SK, Wang L, Liu J, Batkai S, Jarai Z, Fezza F, Miura GI, Palmiter RD, Sugiura T and Kunos G (2001) Leptin-regulated endocannabinoids are involved in maintaining food intake. Nature 410:822-825.

Doty RL (2008) The olfactory vector hypothesis of neurodegenerative disease: is it viable? Ann Neurol 63:7-15.

Doty RL (2009) The olfactory system and its disorders. Semin Neurol 29:74-81.

Doyle KL, Kazda A, Hort Y, McKay SM and Oleskevich S (2007) Differentiation of adult mouse olfactory precursor cells into hair cells in vitro. Stem Cells 25:621627.

Drew LJ, Rugiero F, Cesare P, Gale JE, Abrahamsen B, Bowden S, Heinzmann S, Robinson M, Brust A, Colless B, Lewis RJ and Wood JN (2007) High-threshold mechanosensitive ion channels blocked by a novel conopeptide mediate pressureevoked pain. PLOS ONE 2:e515.

Drew LJ and Wood JN (2007) FM1-43 is a permeant blocker of mechanosensitive ion channels in sensory neurons and inhibits behavioural responses to mechanical stimuli. Mol Pain 3:1.

Duchamp-Viret P, Duchamp A and Chaput MA (2000) Peripheral odor coding in the rat and frog: quality and intensity specification. $J$ Neurosci 20:2383-2390. 
Egertová M and Elphick MR (2000) Localisation of cannabinoid receptors in the rat brain using antibodies to the intracellular C-terminal tail of CB. J Comp Neurol 422:159-171.

Eisthen HL, Delay RJ, Wirsig-Wiechmann CR and Dionne VE (2000) Neuromodulatory effects of gonadotropin releasing hormone on olfactory receptor neurons. J Neurosci 20:3947-3955.

Elinson RP (2001) Xenopus as an experimental organism. Encyclopedia of Life Sciences, John Wiley and Sons, Ltd.

Ellis J, Pediani JD, Canals M, Milasta S and Milligan G (2006) Orexin-1 receptorcannabinoid CB1 receptor heterodimerization results in both ligand-dependent and -independent coordinated alterations of receptor localization and function. $J$ Biol Chem 281:38812-38824.

Elphick MR and Egertová M (2001) The neurobiology and evolution of cannabinoid signalling. Philos Trans R Soc Lond B Biol Sci 356:381-408.

Engeli $S$ (2008) Dysregulation of the endocannabinoid system in obesity. $J$ Neuroendocrinol 20:110-115.

Farbman Al (1992) The Cell Biology of Olfaction. New York: Cambridge University Press.

Féron F, Vincent A and Mackay-Sim A (1999) Dopamine promotes differentiation of olfactory neuron in vitro. Brain Res 845:252-259.

Firestein S (2001) How the olfactory system makes sense of scents. Nature 413:211218.

Freitag J, Ludwig G, Andreini I, Rössler P and Breer H (1998) Olfactory receptors in aquatic and terrestrial vertebrates. J Comp Physiol A 183: 635-650.

Frings S, Lynch JW and Lindemann B (1992) Properties of cyclic nucleotide-gated channels mediating olfactory transduction. Activation, selectivity, and blockage. $J$ Gen Physiol 100:45-67.

Frings S, Seifert R, Godde M and Kaupp BU (1995) Profoundly Different calcium Permeation and Blockage Determine the Specific Function of Distinct Cyclic Nucleotide-Gated Channels. Neuron 15:169-179. 
Fukudome Y, Ohno-Shosaku T, Matsui M, Omori Y, Fukaya M, Tsubokawa H, Taketo MM, Watanabe M, Manabe T and Kano M (2004) Two distinct classes of muscarinic action on hippocampal inhibitory synapses: M2-mediated direct suppression and M1/M3-mediated indirect suppression through endocannabinoid signalling. Eur J Neurosci 19:2682-2692.

Gale JE, Marcotti W, Kennedy HJ, Kros CJ and Richardson GP (2001) FM1-43 dye behaves as a permeant blocker of the hair-cell mechanotransducer channel. $J$ Neurosci. 21:7013-7025.

Galve-Roperh I, Aguado T, Palazuelos J and Guzmán M (2008) Mechanisms of control of neuron survival by the endocannabinoid system. Curr Pharm Des 14:2279-2288.

Galve-Roperh I, Rueda D, Gómez del Pulgar T, Velasco G and Guzmán M (2002) Mechanism of extracellular signal-regulated kinase activation by the $\mathrm{CB}(1)$ cannabinoid receptor. Mol Pharmacol 62:1385-1392.

Gaoni Y and Mechoulam R (1964) Isolation, structure and partial synthesis of an active constituent of hashish. J Am Chem Soc 86:1646-1647.

Gautam SH, Otsuguro KI, Ito S, Saito T and Habara Y (2006) T-type Ca2+ channels mediate propagation of odor-induced $\mathrm{Ca} 2+$ transients in rat olfactory receptor neurons. Neuroscience 144:702-713.

Gebremedhin D, Lange AR, Campbell WB, Hillard CJ and Harder DR (1999) Cannabinoid CB1 receptor of cat cerebral arterial muscle functions to inhibit L-type Ca2+ channel current. Am J Physiol 276:H2085-H2093.

Getchell ML and Getchell TV (1992) Fine structural aspects of secretion and extrinsic innervation in the olfactory mucosa. Microsc Res Tech 23:111-127.

Getchell TV (1986) Functional properties of vertebrate olfactory receptor neurons. Physiol Rev 66:772-818.

Getchell TV, Kwong K, Saunders CP, Stromberg AJ and Getchell ML (2006) Leptin regulates olfactory-mediated behavior in ob/ob mice. Physiol Behav 87:848-56. 
Ghatpande AS, Uma R and Karpen JW (2003) A multiply charged tetracaine derivative blocks cyclic nucleotide-gated channels at subnanomolar concentrations. Biochemistry 42:265-270.

Giuffrida A, Leweke FM, Gerth CW, Schreiber D, Koethe D, Faulhaber J, Klosterkötter J and Piomelli D (2004) Cerebrospinal anandamide levels are elevated in acute schizophrenia and are inversely correlated with psychotic symptoms. Neuropsychopharmacology 29:2108-2114.

Gliem S, Schild D and Manzini I (2009) Highly specific responses to amine odorants of individual olfactory receptor neurons in situ. Eur J Neurosci 29:2315-2326.

Gold GH (1999) Controversial issues in vertebrate olfactory transduction. Annu Rev Physiol 61:857-871.

Gorzalka BB, Hill MN and Hillard CJ (2008) Regulation of endocannabinoid signaling by stress: implications for stress-related affective disorders. Neurosci Biobehav Rev 32:1152-1160.

Grant L and Fuchs PA (2007) Auditory transduction in the mouse. Pflugers Arch 454:793-804.

Grosmaitre X, Vassalli A, Mombaerts P, Shepherd GM and Ma M (2005) Odorant responses of olfactory sensory neurons expressing the odorant receptor MOR23: a patch clamp analysis in gene-targeted mice. Proc Natl Acad Sci U S A 103:1970-1975.

Halpern M (1987) The organization and function of the vomeronasal system. Annu Rev Neurosci 10:325-362.

Hamill OP, Marty A, Neher E, Sakmann B and Sigworth FJ (1981) Improved patchclamp techniques for high-resolution current recording from cells and cell-free membrane patches. Pflugers Arch 391:85-100.

Hampson AJ, Bornheim LM, Scanziani M, Yost CS, Gray AT, Hansen BM, Leonoudakis DJ and Bickler PE (1998) Dual effects of anandamide on NMDA receptor-mediated responses and neurotransmission. J Neurochem 70:671-676. 
Hansen A, Reiss J, Gentry C and Burd G (1998) Ultrastructure of the Olfactory Organ in the Clawed Frog, Xenopus laevis, During Larval Development and Metamorphosis. J Comp Neurol 398:273-288.

Harkany T, Mackie $\mathrm{K}$ and Doherty $\mathrm{P}$ (2008) Wiring and firing neuronal networks: endocannabinoids take center stage. Curr Opin Neurobiol 18:338-345.

Hart CL, Ward AS, Haney M, Comer SD, Foltin RW and Fischman WM (2002) Comparison of smoked marijuana and oral Delta(9)-tetrahydrocannabinol in humans. Psychopharmacology (Berl) 164:407-415.

Hashimotodani Y, Ohno-Shosaku T and Kano M (2007) Ca(2+)-assisted receptordriven endocannabinoid release: mechanisms that associate presynaptic and postsynaptic activities. Curr Opin Neurobiol 17:360-365.

Hashimotodani Y, Ohno-Shosaku T, Maejima T, Fukami K and Kano M (2008) Pharmacological evidence for the involvement of diacylglycerol lipase in depolarization-induced endocanabinoid release. Neuropharmacology 54:58-67.

Hass N, Haub H, Stevens R, Breer H and Schwarzenbacher K (2008) Expression of adiponectin receptor 1 in olfactory mucosa of mice. Cell Tissue Res 334:187-97.

Hassenklöver T, Kurtanska S, Bartoszek I, Junek S, Schild D and Manzini I (2008) Nucleotide-induced $\mathrm{Ca}^{2+}$ signaling in sustentacular supporting cells of the olfactory epithelium. Glia 56:1614-1624.

Hassenklöver T, Schwartz P, Schild D and Manzini I (2009) Purinergic Signaling Regulates Cell Proliferation of Olfactory Epithelium Progenitors. Stem Cells 27:2022-2031.

Haynes LW (1992) Block of the cyclic GMP-gated channel of vertebrate rod and cone photoreceptors by I-cis-diltiazem. J Gen Physiol 100:783-801.

Hegg CC, Greenwood D, Huang W, Han P and Lucero MT (2003) Activation of purinergic receptor subtypes modulates odor sensitivity. J Neurosci 23:8291-8301.

Hegg CC and Lucero MT (2004) Dopamine reduces odor- and elevated-K(+)-induced calcium responses in mouse olfactory receptor neurons in situ. J Neurophysiol 91:1492-1499. 
Hegg CC and Lucero MT (2006) Purinergic receptor antagonists inhibit odorantinduced heat shock protein 25 induction in mouse olfactory epithelium. Glia 53:182-190.

Herkenham M, Lynn AB, Johnson MR, Melvin LS, de Costa BR and Rice KC (1991) Characterization and localization of cannabinoid receptors in rat brain: a quantitative in vitro autoradiographic study. $J$ Neurosci 11:563-583.

Herkenham M, Lynn AB, Little MD, Johnson MR, Melvin LS, de Costa BR and Rice KC (1990) Cannabinoid receptor localization in brain. Proc Natl Acad Sci U S A 87:1932-1936.

Hilairet S, Bouaboula M, Carrière D, Le Fur G and Casellas P (2003) Hypersensitization of the Orexin 1 receptor by the CB1 receptor: evidence for cross-talk blocked by the specific CB1 antagonist, SR141716. J Biol Chem 278:23731-23737.

Horvath TL (2006) The unfolding cannabinoid story on energy homeostasis: central or peripheral site of action? Int J Obes (Lond) 30:30-32.

Howlett AC (2005) Cannabinoid receptor signaling. Handb Exp Pharmacol 168:5379.

Howlett AC, Barth F, Bonner TI, Cabral G, Casellas P, Devane WA, Felder CC, Herkenham M, Mackie K, Martin BR, Mechoulam R and Pertwee RG (2002) International Union of Pharmacology. XXVII. Classification of cannabinoid receptors. Pharmacol Rev 54:161-202.

Huang CC, Lo SW and Hsu KS (2001) Presynaptic mechanisms underlying cannabinoid inhibition of excitatory synaptic transmission in rat striatal neurons. $J$ Physiol 532:731-748.

Hungund BL, Vinod KY, Kassir SA, Basavarajappa BS, Yalamanchili R, Cooper TB, Mann JJ and Arango V (2004) Upregulation of CB1 receptors and agoniststimulated [35S]GTPgammaS binding in the prefrontal cortex of depressed suicide victims. Mol Psychiatry 9:184-190.

lida A and Kashiwayanagi M (1999) Responses of Xenopus laevis water nose to water-soluble and volatile odorants. J Gen Physiol 114:85-92. 
Imanaka Y and Takeuchi H (2001) Spiking properties of olfactory receptor cells in the slice preparation. Chem Senses 26:1023-1027.

Jo YH, Chen YJ, Chua SC Jr, Talmage DA and Role LW (2005) Integration of endocannabinoid and leptin signaling in an appetite-related neural circuit. Neuron 48:1055-1066.

Juan-Picó P, Fuentes E, Bermúdez-Silva FJ, Javier Díaz-Molina F, Ripoll C, Rodríguez de Fonseca F and Nadal A (2006) Cannabinoid receptors regulate $\mathrm{Ca}(2+)$ signals and insulin secretion in pancreatic beta-cell. Cell Calcium 39:155162.

Julliard AK, Chaput MA, Apelbaum A, Aimé $P$, Mahfouz $M$ and Duchamp-Viret $P$ (2007) Changes in rat olfactory detection performance induced by orexin and leptin mimicking fasting and satiation. Behav Brain Res 183:123-129.

Junek S, Chen T-W, Alevra M and Schild D (2009) Activity correlation imaging: visualizing function and structure of neuronal populations. Biophys $J$ 96:38013809.

Kajiya K, Inaki K, Tanaka M, Haga T, Kataoka H and Touhara K (2001) Molecular bases of odor discrimination: reconstitution of olfactory receptors that recognize overlapping sets of odorants. J Neurosci 21:6018-6025.

Kang J and Caprio J (1995) In vivo responses of single olfactory receptor neurons in the channel catfish, Ictalurus punctatus. J Neurophysiol 73:172-177.

Kano M, Ohno-Shosaku T, Hashimotodani Y, Uchigashima M and Watanabe M (2009) Endocannabinoid-mediated control of synaptic transmission. Physiol Rev 89:309-380.

Kaupp B and Seifert R (2002) Cyclic Nucleotide-Gated Ion Channels. Physiol Rev 82:769-824.

Kaur R, Zhu XO, Moorhouse AJ and Barry PH (2001) IP3-gated channels and their occurrence relative to CNG channels in the soma and dendritic knob of rat olfactory receptor neurons. J Membr Biol 181:91-105.

Kawai F, Kurahashi T and Kaneko A (1999) Adrenaline enhances odorant contrast by modulating signal encoding in olfactory receptor cells. Nat Neurosci 2:133-138. 
Kay AR, Alfonso A, Alford S, Cline HT, Holgado AM, Sakmann B, Snitsarev VA, Stricker TP, Takahashi M and Wu LG (1999) Imaging synaptic activity in intact brain and slices with FM1-43 in C. elegans, lamprey, and rat. Neuron 24:809-817.

Khakh BS, Bao XR, Labarca C and Lester HA (1999) Neuronal P2X transmittergated cation channels change their ion selectivity in seconds. Nat Neurosci 2:322330 .

Kidokoro Y, Kuromi H, Delgado R, Maureira C, Oliva C and Labarca P (2004) Synaptic vesicle pools and plasticity of synaptic transmission at the Drosophila synapse. Brain Res Brain Res Rev 47:18-32.

Kleene SJ (2000) Spontaneous Gating of Olfactory Cyclic-Nucleotide-Gated Channels. J Membrane Biol 178:49-54.

Kleene SJ (2008) The electrochemical basis of odor transduction in vertebrate olfactory cilia. Chem Senses 33:839-859.

Klein SL and Graziadei PP (1993) The differentiation of the olfactory-placode in Xenopus laevis: a light and electron microscope study. J Comp Neurol 217:17-30.

Kirkham TC and Tucci SA (2006) Endocannabinoids in appetite control and the treatment of obesity. CNS Neurol Disord Drug Targets 5:272-292.

Kirkham TC, Williams C, Fezza F and Di Marzo V (2002) Endocannabinoid levels in rat limbic forebrain and hypothalamus in relation to fasting, feeding and satiation: stimulation of eating by 2-arachidonoyl glycerol. Br J Pharmacol 136: 550-557.

Ko HJ and Park TH (2006) Dual signal transduction mediated by a single type of olfactory receptor expressed in a heterologous system. Biol Chem 387:59-68.

Koch KW and Kaupp UB (1985) Cyclic GMP directly regulates a cation conductance in membranes of bovine rods by a cooperative mechanism. J Biol Chem 260:6788-6800.

Kubista M, Andrade JM, Bengtsson M, Forootan A, Jonák J, Lind K, Sindelka R, Sjöback R, Sjögreen B, Strömbom L, Ståhlberg A and Zoric N (2006) The realtime polymerase chain reaction. Mol Aspects Med 27:95-125

Lang F and Lang P (2007) Basiswissen Physiologie, 2nd edition (Springer Berlin Heidelberg). 
Lauckner JE, Jensen JB, Chen HY, Lu HC, Hille B and Mackie K (2008) GPR55 is a cannabinoid receptor that increases intracellular calcium and inhibits $M$ current. Proc Natl Acad Sci U S A 105:2699-2704.

Lazard D, Zupko K, Poria Y, Nef P, Lazarovits J, Horn S, Khen M and Lancet D (1991) Odorant signal termination by olfactory UDP glucuronosyl transferase. Nature 349:790-793.

Lazic SE, Goodman AO, Grote HE, Blakemore C, Morton AJ, Hannan AJ, van Dellen A and Barker RA (2007) Olfactory abnormalities in Huntington's disease: decreased plasticity in the primary olfactory cortex of $R 6 / 1$ transgenic mice and reduced olfactory discrimination in patients. Brain Res 1151:219-226.

Leinders-Zufall T, Ma M and Zufall F (1999) Impaired odor adaptation in olfactory receptor neurons after inhibition of $\mathrm{Ca}^{2+} /$ calmodulin kinase II. J Neurosci 19:RC19.

Leinders-Zufall T and Zufall F (1995) Block of cyclic nucleotide-gated channels in salamander olfactory receptor neurons by the guanylyl cyclase inhibitor LY83583. J Neurophysiol 74:2759-2762.

Lischka FW and Schild D (1993) Standing calcium gradients in olfactory receptor neurons can be abolished by amiloride or ruthenium red. J Gen Physiol 102:817831.

Liu M, Chen TY, Ahamed B, Li J and Yau KW (1994) Calcium-calmodulin modulation of the olfactory cyclic nucleotide-gated cation channel. Science 266:1348-1354.

Lledo PM, Gheusi G and Vincent JD (2005) Information processing in the mammalian olfactory system. Physiol Rev 85:281-317.

Lombion-Pouthier S, Vandel P, Nezelof S, Haffen E and Millot JL (2006) Odor perception in patients with mood disorders. J Affect Disord 90:187-191.

Lucero MT, Huang W and Dang T (2000) Immunohistochemical evidence for the $\mathrm{Na}+/ \mathrm{Ca} 2+$ exchanger in squid olfactory neurons. Philos Trans $R$ Soc Lond B Biol Sci 355:1215-1218.

Mackie K (2005) Cannabinoid receptor homo- and heterodimerization. Life Sci 77:1667-1673. 
Mackie K (2008) Cannabinoid receptors: where they are and what they do. J Neuroendocrinol 20:10-14.

Mackie K and Hille B (1992) Cannabinoids inhibit N-type calcium channels in neuroblastoma-glioma cells. Proc Natl Acad Sci U S A 89:3825-3829.

Mackie K, Lai Y, Westenbroek R and Mitchell R (1995) Cannabinoids activate an inwardly rectifying $\mathrm{K}^{+}$conductance and inhibit $\mathrm{Q}$-type calcium currents in AtT20 cells transfected with rat brain cannabinoid receptor. J Neurosci 15:6552-6561.

Malnic B, Hirono J, Sato T and Buck LB (1999) Combinatorial receptor codes for odors. Cell 96:713-723.

Manzini I, Rössler W and Schild D (2002) cAMP-independent responses of olfactory neurons in Xenopus laevis tadpoles and their projection onto olfactory bulb neurons. J Physiol 545:475-484.

Manzini I and Schild D (2003a) cAMP-independent olfactory transduction of amino acids in Xenopus laevis tadpoles. J Physiol 551:115-123.

Manzini I and Schild D (2003b) Multidrug resistance transporters in the olfactory receptor neurons of Xenopus laevis tadpoles. J Physiol 546:375-385.

Manzini I and Schild D (2004) Classes and narrowing selectivity of olfactory receptor neurons of Xenopus laevis tadpoles. J Gen Physiol 123:99-107.

Marcellino D, Carriba P, Filip M, Borgkvist A, Frankowska M, Bellido I, Tanganelli S, Müller CE, Fisone G, Lluis C, Agnati LF, Franco R and Fuxe K (2008) Antagonistic cannabinoid CB1/dopamine D2 receptor interactions in striatal CB1/D2 heteromers. A combined neurochemical and behavioral analysis. Neuropharmacology 54:815-823.

Mathonnet M, Comte I, Lalloué F and Ayer-Le Lièvre C (2001) Insulin-like growth factor I induced survival of axotomized olfactory neurons in the chick. Neurosci Lett 308:67-70.

Matias I, Cristino L and Di Marzo V (2008) Endocannabinoids: some like it fat (and sweet too). J Neuroendocrinol 20:100-109.

Matias I and Di Marzo V (2007) Endocannabinoids and the control of energy balance. Trends Endocrinol Metab 18:27-37. 
Matsuda LA, Lolait SJ, Brownstein MJ, Young AC and Bonner TI (1990) Structure of a cannabinoid receptor and functional expression of the cloned cDNA. Nature 346:561-564.

McAllister SD, Griffin G, Satin LS and Abood ME (1999) Cannabinoid receptors can activate and inhibit $G$ protein-coupled inwardly rectifying potassium channels in a xenopus oocyte expression system. J Pharmacol Exp Ther 291:618-826.

McLaughlin PJ, Winston K, Swezey L, Wisniecki A, Aberman J, Tardif DJ, Betz AJ, Ishiwari K, Makriyannis A and Salamone JD (2003) The cannabinoid CB1 antagonists SR 141716A and AM 251 suppress food intake and food-reinforced behavior in a variety of tasks in rats. Behav Pharmacol 14:583-588.

Meyers JR, MacDonald RB, Duggan A, Lenzi D, Standaert DG, Corwin JT and Corey DP (2003) Lighting up the senses: FM1-43 loading of sensory cells through nonselective ion channels. J Neurosci 23:4054-4065.

Migliarini B, Marucci G, Ghelfi F and Carnevali O (2006) Endocannabinoid system in Xenopus laevis development: CB1 receptor dynamics. FEBS Lett 580:1941-1945.

Miragall F, Krause D, de Vries U and Dermietzel R (1994) Expression of the tight junction protein ZO-1 in the olfactory system: presence of ZO-1 on olfactory sensory neurons and glial cells. J Comp Neurol 341:433-448.

Mombaerts P (1999) Molecular biology of odorant receptors in vertebrates. Annu Rev Neurosci 22:487-509.

Mombaerts P (2004) Odorant receptor gene choice in olfactory sensory neurons: the one receptor-one neuron hypothesis revisited. Curr Opin Neurobiol 14:31-36.

Mombaerts P, Wang F, Dulac C, Chao SK, Nemes A, Mendelsohn M, Edmondson J and Axel R (1996) Visualizing an olfactory sensory map. Cell 87:675-686.

Montani G, Tonelli S, Elsaesser R, Paysan J and Tirindelli R (2006) Neuropeptide Y in the olfactory microvillar cells. Eur J Neurosci 24:20-24.

Morales B, Madrid R and Bacigalupo J (1997) Calcium mediates the activation of the inhibitory current induced by odorants in toad olfactory receptor neurons. FEBS Lett 402:259-264. 
Mori K, Nagao H and Yoshihara Y (1999) The olfactory bulb: coding and processing of odor molecule information. Science 286:711-715.

Morisset V, Ahluwalia J, Nagy I and Urban L (2001) Possible mechanisms of cannabinoid-induced antinociception in the spinal cord. Eur J Pharmacol 429:93100.

Morrison EE and Moran DT (1995) Anatomy and ultrastructure of the human olfactory neuroepithelium, in: R.L. Doty (Ed.), Handbook of Olfaction and Gustation, Marcel Dekker, New York, pp. 75-101.

Mousley A, Polese G, Marks NJ and Eisthen HL (2006) Terminal nerve-derived neuropeptide y modulates physiological responses in the olfactory epithelium of hungry axolotls (Ambystoma mexicanum). J Neurosci 26:7707-7717.

Mulder J, Aguado T, Keimpema E, Barabás K, Ballester Rosado CJ, Nguyen L, Monory K, Marsicano G, Di Marzo V, Hurd YL, Guillemot F, Mackie K, Lutz B, Guzmán M, Lu HC, Galve-Roperh I and Harkany T (2008) Endocannabinoid signaling controls pyramidal cell specification and long-range axon patterning. Proc Natl Acad Sci U S A 105:8760-8765.

Munro S, Thomas KL and Abu-Shaar M (1993) Molecular characterization of a peripheral receptor for cannabinoids. Nature 365:61-65.

Neuhaus EM, Gisselmann G, Zhang W, Dooley R, Störtkuhl K and Hatt H (2004) Odorant receptor heterodimerization in the olfactory system of Drosophila melanogaster. Nat Neurosci 8:15-17.

Nicol GD, Schnetkamp PP, Saimi Y, Cragoe EJ Jr and Bownds MD (1987) A derivative of amiloride blocks both the light-regulated and cyclic GMP-regulated conductances in rod photoreceptors. J Gen Physio/ 90:651-669.

Nieuwkoop PD and Faber J (1994) Normal Table of Xenopus laevis (Daudin) (Garland, New York).

Niimura $\mathrm{Y}$ and Nei M (2006) Evolutionary dynamics of olfactory and other chemosensory receptor genes in vertebrates. J Hum Genet 51:505-517.

Nimmermark S (2004) Odour influence on well-being and health with specific focus on animal production emissions. Ann Agric Environ Med 11:163-173. 
Nishikawa S and Sasaki F (1996) Internalization of styryl dye FM1-43 in the hair cells of lateral line organs in Xenopus larvae. J Histochem Cytochem 44:733-741.

Nordin S and Brämerson A (2008) Complaints of olfactory disorders: epidemiology, assessment and clinical implications. Curr Opin Allergy Clin Immunol 8:10-15.

Oka Y, Nakamura A, Watanabe H and Touhara K (2004a) An odorant derivative as an antagonist for an olfactory receptor. Chem Senses 29:815-822.

Oka Y, Omura M, Kataoka H and Touhara K (2004b) Olfactory receptor antagonism between odorants. EMBO J 23:120-126.

Osei-Hyiaman D, Harvey-White J, Bátkai S and Kunos G (2006) The role of the endocannabinoid system in the control of energy homeostasis. Int $J$ Obes (Lond) 30:33-38.

Pagotto U, Marsicano G, Cota D, Lutz B and Pasquali R (2006) The emerging role of the endocannabinoid system in endocrine regulation and energy balance. Endocr Rev 27:73-100.

Pertwee RG (2007) GPR55: a new member of the cannabinoid receptor clan? $\mathrm{Br} J$ Pharmacol 152:985-986.

Phillips KR, Biswas A and Cyr JL (2008) How hair cells hear: the molecular basis of hair-cell mechanotransduction. Curr Opin Otolaryngol Head Neck Surg 16:445451.

Rankin ML, Alvania RS, Gleason EL and Bruch RC (1999) Internalization of G protein-coupled receptors in single olfactory receptor neurons. J Neurochem 72:541-548.

Rawson NE, Eberwine J, Dotson R, Jackson J, Ulrich P and Restrepo D (2000) Expression of mRNAs encoding for two different olfactory receptors in a subset of olfactory receptor neurons. J Neurochem 75:185-195.

Reisert J and Matthews HR (1998) Na+-dependent Ca2+ extrusion governs response recovery in frog olfactory receptor cells. J Gen Physiol 112:529-535.

Rhee MH, Bayewitch M, Avidor-Reiss T, Levy R and Vogel Z (1998) Cannabinoid receptor activation differentially regulates the various adenylyl cyclase isozymes. $J$ Neurochem 71:1525-1534. 
Richardson JD, Aanonsen L and Hargreaves KM (1998) Hypoactivity of the spinal cannabinoid system results in NMDA-dependent hyperalgesia. $J$ Neurosci 18:451457.

Robledo P, Berrendero F, Ozaita A and Maldonado R (2008) Advances in the field of cannabinoid-opioid cross-talk. Addict Biol 13:213-224.

Rössler P, Mezler M and Breer H (1998) Two olfactory marker proteins in Xenopus laevis. J Comp Neurol 395:273-280.

Rolen SH, Sorensen PW, Mattson D and Caprio J (2003) Polyamines as olfactory stimuli in the goldfish Carassius auratus. J Exp Biol 206:1683-1696.

Rolls ET (2005) Taste, olfactory, and food texture processing in the brain, and the control of food intake. Physiol Behav 85:45-56.

Ronnett GV and Moon C (2002) G proteins and olfactory signal transduction. Annu Rev Physiol 64:189-222.

Saito H, Chi Q, Zhuang H, Matsunami H and Mainland (2009) Odor coding by a Mammalian receptor repertoire. J Sci Signal 60:1-14.

Sakurai T, Amemiya A, Ishii M, Matsuzaki I, Chemelli RM, Tanaka H, Williams SC, Richardson JA, Kozlowski GP, Wilson S, Arch JR, Buckingham RE, Haynes AC, Carr SA, Annan RS, McNulty DE, Liu WS, Terrett JA, Elshourbagy NA, Bergsma DJ and Yanagisawa M (1998) Orexins and orexin receptors: a family of hypothalamic neuropeptides and G protein-coupled receptors that regulate feeding behavior. Cell 92: 573-585.

Sanz G, Schlegel C, Pernollet JC and Briand L (2005) Comparison of Odorant Specificity of Two Human Olfactory Receptors from Different Phylogenetic Classes and Evidence for Antagonism. Chem Senses 30:69-80.

Sato K and Suzuki N (2001) Whole-cell response characteristics of ciliated and microvillous olfactory receptor neurons to amino acids, pheromone candidates and urine in rainbow trout. Chem Senses 26:1145-1156. 
Savigner A, Duchamp-Viret P, Grosmaitre X, Chaput M, Garcia S, Ma M and Palouzier-Paulignan B (2009) Modulation of spontaneous and odor-evoked activity of rat olfactory sensory neurons by two anorectic peptides, insulin and leptin. $J$ Neurophysiol [Epub ahead of print].

Scherma M, Fadda P, Le Foll B, Forget B, Fratta W, Goldberg SR and Tanda G (2008) The endocannabinoid system: a new molecular target for the treatment of tobacco addiction. CNS Neurol Disord Drug Targets 7:468-481.

Schild D (1985) A computer-controlled device for the application of odours to aquatic animals. J Electrophysiol Techn 12:71-79.

Schild D (1989) Whole-cell currents in olfactory receptor cells of Xenopus laevis. Exp Brain Res 78:223-232.

Schild D, Gennerich A and Schultens HA (1996) Microcontrollers as inexpensive pulse generators and parallel processors in electrophysiological experiments. Med Biol Eng Comput 34:305-307.

Schild D, Jung A and Schultens HA (1994) Localization of calcium entry through calcium channels in olfactory receptor neurones using a laser scanning microscope and the calcium indicator dyes Fluo-3 and Fura-Red. Cell Calcium 15:341-348.

Schild D and Manzini I (2004) Cascades of response vectors of olfactory receptor neurons in Xenopus laevis tadpoles. Eur J Neurosci 20:2111-2123.

Schild D and Restrepo D (1998) Transduction mechanisms in vertebrate olfactory receptor cells. Physiol Rev 78:429-466.

Schultz EF and Tapp JT (1973) Olfactory control of behavior in rodents. Psychol Bull 79:21-44.

Schwob JE (2002) Neural regeneration and the peripheral olfactory system. Anat $\operatorname{Rec}$ 269:33-49.

Seiler C and Nicolson T (1999) Defective calmodulin-dependent rapid apical endocytosis in zebrafish sensory hair cell mutants. J Neurobiol 41:424-434.

Semple DM, Mclntosh AM and Lawrie SM (2005) Cannabis as a risk factor for psychosis: systematic review. J Psychopharmacol 19:187-194. 
Soderstrom K, Tian Q, Valenti M, Di Marzo V (2004) Endocannabinoids link feeding state and auditory perception-related gene expression. J Neurosci 24:1001310021.

Steinke A, Meier-Stiegen S, Drenckhahn D and Asan E (2008) Molecular composition of tight and adherens junctions in the rat olfactory epithelium and fila. Histochem Cell Biol 130:339-361.

Stephan AB, Shum EY, Hirsh S, Cygnar KD, Reisert J and Zhao H (2009) ANO2 is the cilial calcium-activated chloride channel that may mediate olfactory amplification. Proc Natl Acad Sci U S A 106:11776-11781.

Straiker A, Stella N, Piomelli D, Mackie K, Karten HJ and Maguire G (1999) Cannabinoid CB1 receptors and ligands in vertebrate retina: localization and function of an endogenous signaling system. Proc Natl Acad Sci U S A 96:1456514570.

Strassmaier T, Uma R, Ghatpande AS, Bandyopadhyay T, Schaffer M, Witte J, McDougal PG, Brown RL and Karpen JW (2005) Modifications to the tetracaine scaffold produce cyclic nucleotide-gated channel blockers with widely varying efficacies. J Med Chem 48:5805-5812.

Struik ML, Yazulla S and Kamermans M (2006) Cannabinoid agonist WIN 55212-2 speeds up the cone response to light offset in goldfish retina. Vis Neurosci 23:285293.

Sugiura T, Kishimoto S, Oka S and Gokoh M (2006) Biochemistry, pharmacology and physiology of 2-arachidonoylglycerol, an endogenous cannabinoid receptor ligand. Prog Lipid Res 45:405-446.

Sugiura T, Kobayashi Y, Oka S and Waku K (2002) Biosynthesis and degradation of anandamide and 2-arachidonoylglycerol and their possible physiological significance. Prostaglandins Leukot Essent Fatty Acids 66:173-192.

Suzuki Y and Takeda M (2002) Expression of insulin-like growth factor family in the rat olfactory epithelium. Anat Embryol (Berl) 205:401-405.

Suzuki Y, Takeda M and Farbman Al (1996) Supporting cells as phagocytes in the olfactory epithelium after bulbectomy. J Comp Neuro/ 376:509-517. 
Szabo B, Urbanski MJ, Bisogno T, Di Marzo V, Mendiguren A, Baer WU and Freiman I (2006) Depolarization-induced retrograde synaptic inhibition in the mouse cerebellar cortex is mediated by 2-arachidonoylglycerol. J Physiol 577:263-280.

Takahashi LK, Nakashima BR, Hong H and Watanabe K (2005) The smell of danger: a behavioral and neural analysis of predator odor-induced fear. Neurosci Biobehav Rev 29:1157-1167.

Takeuchi H and Kurahashi T (2008) Distribution, amplification, and summation of cyclic nucleotide sensitivities within single olfactory sensory cilia. J Neurosci 28:766-775.

Tang CM, Presser F and Morad M (1988) Amiloride selectively blocks the low threshold (T) calcium channel. Science 240:213-215.

Tian $\mathrm{H}$ and Ma M (2008) Activity plays a role in eliminating olfactory sensory neurons expressing multiple odorant receptors in the mouse septal organ. Mol Cell Neurosci 38:484-488.

Tibbs GR, Goulding EH and Siegelbaum SA (1997) Allosteric activation and tuning of ligand efficacy in cyclic-nucleotide-gated channels. Nature 386:612-615.

Tinsley RC and Kobel HR (1996) The Biology of Xenopus, Oxford Science Publications and the Zoological Society of London, Oxford University Press.

Toida K (2008) Synaptic organization of the olfactory bulb based on chemical coding of neurons. Anat Sci Int 83:207-217.

Toller SV (1999) Assessing the impact of anosmia: review of a questionnaire's findings. Chem Senses 24:705-712.

Vargas G and Lucero MT (2002) Modulation by PKA of the hyperpolarizationactivated current (Ih) in cultured rat olfactory receptor neurons. J Membr Biol 188:115-125.

Verty AN, McGregor IS and Mallet PE (2005) Paraventricular hypothalamic CB(1) cannabinoid receptors are involved in the feeding stimulatory effects of Delta(9)tetrahydrocannabinol. Neuropharmacology 49:1101-1109.

Viveros MP, Marco EM and File SE (2005) Endocannabinoid system and stress and anxiety responses. Pharmacol Biochem Behav 81:331-342. 
Vogler C and Schild D (1999) Inhibitory and excitatory responses of olfactory receptor neurons of Xenopus laevis tadpoles to stimulation with amino acids. $J$ Exp Biol 202:997-1003.

Watson S, Chambers D, Hobbs C, Doherty P and Graham A (2008) The endocannabinoid receptor, $\mathrm{CB} 1$, is required for normal axonal growth and fasciculation. Mol Cell Neurosci 38:89-97.

Wei J, Zhao AZ, Chan GCK, Baker LP, Impey S, Beavo JA and Storm DR (1998) Phosphorylation and inhibition of olfactory adenylyl cyclase by CaM kinase II in neurons: a mechanism for attenuation of olfactory signals. Neuron 21:495-504.

Williams EJ, Walsh FS and Doherty P (2003) The FGF receptor uses the endocannabinoid signaling system to couple to an axonal growth response. $J$ Cell Biol 160:481-486.

Wilson RI and Mainen ZF (2006) Early events in olfactory processing. Annu Rev Neurosci 29:163-201.

Yan C, Zhao AZ, Bentley JK, Loughney K, Ferguson K and Beavo JA (1995) Molecular cloning and characterization of a calmodulindependent phosphodiesterase enriched in olfactory sensory neurons. Proc Natl Acad Sci USA 92:9677-9681.

Yeomans MR (2006) Olfactory influences on appetite and satiety in humans. Physiol Behav 87:800-804.

Zavitsanou K, Garrick T and Huang XF (2004) Selective antagonist [3H]SR141716A binding to cannabinoid CB1 receptors is increased in the anterior cingulate cortex in schizophrenia. Prog Neuropsychopharmacol Biol Psychiatry 28:355-360.

Zhuang Y, Cragoe EJ Jr, Shaikewitz T, Glaser L and Cassel D (1984) Characterization of potent $\mathrm{Na}+/ \mathrm{H}+$ exchange inhibitors from the amiloride series in A431 cells. Biochemistry 23:4481-4488.

Zyromski NJ, Mathur A, Pitt HA, Wade TE, Wang S, Swartz-Basile DA, Prather AD and Lillemoe KD (2009) Cannabinoid receptor-1 blockade attenuates acute pancreatitis in obesity by an adiponectin mediated mechanism. J Gastrointest Surg 13:831-838. 


\section{Acknowledgements}

My special thanks go to

Prof. Schild and Dr. Czesnik for the theme, continuous support and their enthusiasm during the progress of this thesis. The many discussions, advices and suggestions were very helpful throughout this thesis.

Prof. Moser and Prof. Stühmer from my PhD committee. They gave useful suggestions and comments during the committee meetings.

Dr. Benjamin Guterman for the dose-response measurements.

Eugen Kludt with whom I carried out the uncaging and olfactory bulb whole mount preparation experiments.

Dr. Gabriela Salinas-Riester and Susanne Luthin from the DNA Microarray Facility for their advice, help and equipment regarding some molecular biology experiments.

Dr. Klaus Jung from the Department of Medical Statistics, who advised me how to evaluate the real-time PCR data.

Prof. Fuchs and Prof. Flügge from the German Primate Center for tissue from rats and tree shrews.

Prof. Hummel from the University of Dresden Medical School for the cDNA of human olfactory epithelium.

everybody from the lab for the constructive atmosphere. Special thanks go to Arwed, Gudrun, Ivan, Mihai, Sebastian, and Stephan for discussions and support in manifold issues and non-professional conversations. Thanks to Arwed, Ivan, Sebastian, and Stephan for reading parts of the thesis.

the state of Lower Saxony and the Bernstein Center for Computational Biology, who provided the funding for my work.

My warmest thanks go to my parents, my sister Miriam and Christian Quack, who made this way possible and continuously encouraged and strengthened me. 


\section{Curriculum Vitae}

Personal data

$\begin{array}{ll}\text { Name } & \text { Esther Breunig } \\ \text { Date of birth } & 24.03 .1983 \\ \text { Place of birth } & \text { Buchen } \\ \text { Address } & \text { Hannoversche Str. 137A, 37077 Göttingen } \\ \text { Phone } & +49551395937 \\ \text { eMail } & \text { ebreuni@gwdg.de } \\ \text { Nationality } & \text { German }\end{array}$

Education

since $10 / 2006$

PhD thesis

Department of Neurophysiology and Cellular Biophysics, Georg-August-Universität Göttingen

Supervisor: Prof. D. Schild

since $10 / 2005$

MSc/PhD/MD-PhD Neurosciences Program

International Max Planck Research School for

Neurosciences, Göttingen

10/2002 - 09/2005 Molecular Biotechnology (BSc)

Ruprecht-Karls-Universität Heidelberg

09/1993 - 06/2002 Burghardt-Gymnasium Buchen

(university-entrance diploma) 


\section{List of publications}

Breunig E, Manzini I, Gutermann B, Schild D and Czesnik D. The endocannabinoid system controls odor sensitivity. Submitted

Breunig E, Kludt E, Czesnik D and Schild D. The styryl dye FM1-43 permeates and blocks CNG channels in olfactory neurons of larval Xenopus laevis. In preparation 